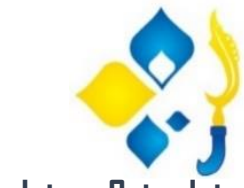

Jatavu Catra Internusa

\title{
Research Methods Information Technology
}

Lila Setiyani,S.T,M.Kom 
Karya ini dilindungi Undang-Undan8 Republik Indonesia Nomor 28 Tahun 2014 Tentang Hak Cipta 


\title{
Research Methods Information Technology
}

\author{
oleh: Lila Setiyani,S.T,M.Kom \\ C) 2018 \\ No ISBN : 978-602-53689-2-9 \\ Desain cover: Lila Setiyani,S.T,M.Kom \\ diterbitkan oleh \\ Jatayu catra Internusa \\ Email : jatayu98@gmail.com
}

CV. Jatayu Catra Internusa
J1. Raya Lemahabang - Pancawati
Karawang, Jawa Barat
Telp: 0267-862135I / 08 I I I 282222

Hak Cipta dilindungi oleh Undang-Undang.

Dilarang mengutip atau memperbanyak sebagian atau seluruh isi buku ini tanpa izin tertulis dari Penerbit. 
Untuk :

Gatot Catra Kastara Nayaka Catra Kastara Nararya Catra Kastara 
Alhamdulilahi Rabbil Alamin, akhirnya penulisan buku ini dapat diselesaikan. Buku ini merupakan perbaikan dari buku sebelumnya yang berjudul metode penelitian teknologi informasi. Perbedaan dari buku sebelumnya adalah terdapatnya metodologi - metodologi penelitian dalam teknologi informasi yang dibahas secara mendalam sehingga dapat mempermudah dalam memahami langkah - langkah penelitian penelitian.

Dalam buku ini juga ditegaskan tentang metode penelitian yang sesuai digunakan dalam bidang penelitian teknologi informasi, serta memberikan contoh kerangka - kerangka laporan penelitian berdasarkan topik - topik teknologi informasi. Harapan penulis buku ini dapat membantu para pembaca yang kesulitan dalam melakukan penelitian tugas akhirnya.

Penulis menyadari bahwa buku ini masih banyak kekurangan, sehingga kritik dan saran dari pakar, praktisi dan pembaca termasuk mahasiswa sangat diharapkan untuk kesempurnaan buku ini.

Akhir kata penulis sampaikan selamat membaca

Karawang, Desember 2018

Lila Setiyani, S.T, M.Kom 
Daftar Isi

Kata Pengantar …………………………………...........

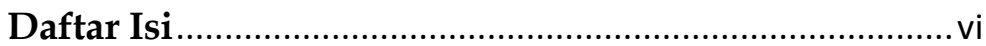

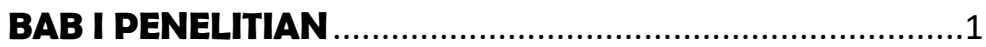

1.1. Pentingnya Meneliti ......................................................

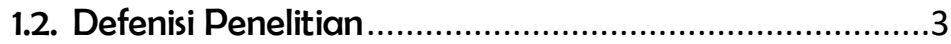

1.3. Tahapan Penelitian ..................................................

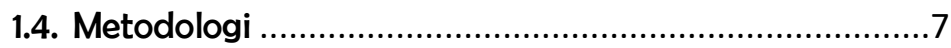

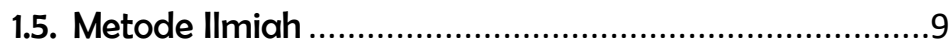

1.6. Metodologi Pengembangan Jaringan Komputer........11

1.7. Metodologi Pengembangan Sistem Informasi .............19

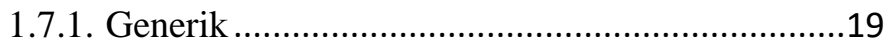

1.7.2. Perspektif...............................................................21

1.7.3. Agile Methods .......................................................30

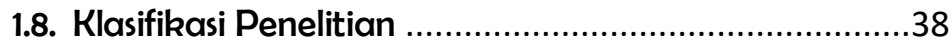

1.9. Proposal Penelitian ......................................................43

BAB II TOPIK PENELITIAN , LATAR BELAKANG DAN PERUMUSAN MASALAH , HIPOTESIS .............................47

2.1. Topik Penelitian ......................................................... 47

2.2. Latar Belakang dan Perumusan Masalah ..................55

2.3. Tujuan Penelitian .........................................................62 
2.4. Ruang Lingkup Penelitian atau Batasan Masalah

Penelitian .63

2.5. Merumuskan Hipotesis ............................................64

BAB III KAJIAN PUSTAKA ..........................................67

3.1. Pengertian Kajian Pustaka....................................67

3.2. Fungsi dan Tujuan Kajian Pustaka ..........................70

3.3. Mencari Referensi di Internet ...................................73

3.4. Meringkas Referensi Penting.....................................78

3.5. Membuat Peta Pikiran dari Referensi - Referensi

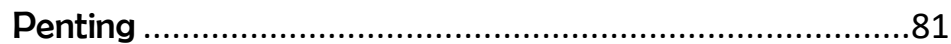

3.6. Menemukan Celah di Bidang Ilmu yang sedang diteliti 83

3.7. Menemukan Keaslian Penelitian ..............................85

3.8. Mengelola Referensi ................................................ 86

3.9. Penyusunan Kajian Pustaka...................................89

3.10. Proses Telaah Pustaka .........................................91

3.11. Pengembangan Teori ...............................................91

3.12. Pengembangan Model.....................................92

3.13. Jenis - jenis Model ............................................93

3.14. Elemen Pengembangan Model...........................93

3.15. Parameterisasi Model ........................................94

3.16. Penelitian Terdahulu ...........................................97

BAB IV DESAIN PENELITIAN .....................................99

4.1. Fungsi Desain Penelitian ........................................99 
4.2. Hal - hal Penting Terkait Desain Penelitian .............100

4.3. Faktor yang Mempengaruhi Desain Penelitian ........101 BAB V VARIABEL PENELITIAN DAN PENGUKURANNYA

5.1. Variabel Penelitian ................................................103

5.2. Jenis - jenis Variabel..............................................103

5.3. Hubungan antar Variabel .....................................105

5.4. Pengukuran Variabel ...........................................106

5.5. Skala Pengukuran Variabel ..................................106

5.6. Jenis Pengukuran Variabel .....................................108

BAB VI POPULASI DAN SAMPEL ...............................109

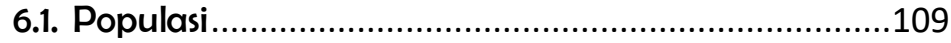

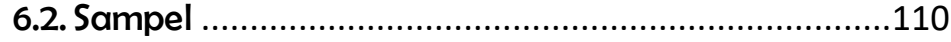

6.3. Syarat - Syarat Sampel yang Baik ........................113

6.4. Teknik Pengambilan Sampel ................................113

6.5. Teknik Pengambilan Sampel ................................117

BAB VII SUMBER DATA DAN PENGUMPULAN DATA ..118

7.1. Ketersediaan Data .................................................118

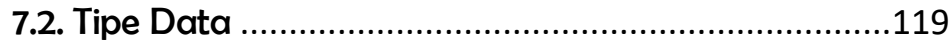

7.3. Sumber Data.......................................................120

7.4. Pengumpulan Data ................................................120

BAB VIII VALIDITAS DAN RELIABILITAS .....................129 


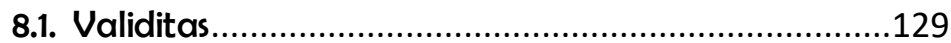

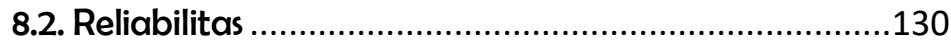

8.3. Validitas Eksternal dan Internal..............................131

8.4. Pengujian Validitas Instrumen ................................132

8.5. Pengujian Reabilitas Instrumen .............................132

8.6. Instrumen Penelitian ...............................................133

\section{BAB IX ANALISIS DAN INTERPRETASI DATA ................136}

9.1. Analisis Data...............................................................136

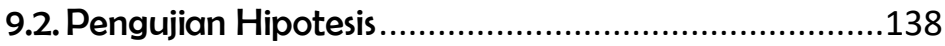

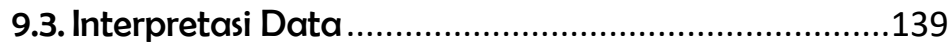

9.4. Statistik Deskriptif ....................................................139

9.5. Statistik Inferensial .............................................140

BAB X TEMUAN PENELITIAN .................................142

BAB XI PENULISAN LAPORAN PENELITIAN ................144

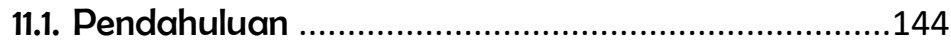

1. Latar Belakang .........................................144

2. Rumusan Masalah .......................................146

3. Tujuan Penelitian .....................................147

4. Manfaat Penelitian .....................................147

5. Metode Penelitian .......................................147

6. Ruang Lingkup ........................................147

11.2. Kajian Pustaka........................................................148

11.3. Analisis, Pemodelan dan Perancangan ....................148 
11.4. Hasil dan Pembahasan..........................................149

11.5. Simpulan , Implikasi dan Saran ...............................150

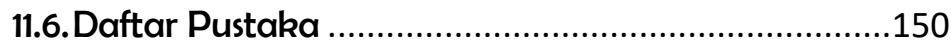

\section{BAB XII CONTOH KERANGKA LAPORAN PENELITIAN} PRAKTEK KERJA LAPANGAN...................................151

12.1. Judul ..................................................................... 151

12.2. Lembar Persetujuan ...........................................151

12.3. Lembar Pernyataan ........................................152

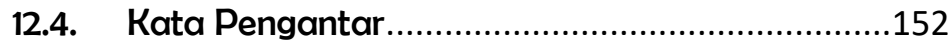

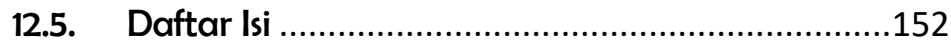

12.6. Daftar Lampiran ...........................................152

12.7. Daftar Tabel ........................................................152

12.8. Daftar Simbol ....................................................152

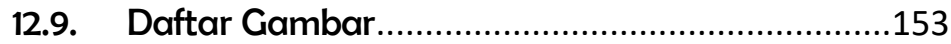

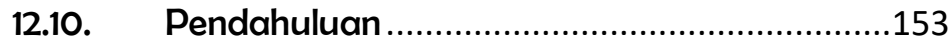

12.11. Hasil Pelaksanaan Praktek Kerja Lapangan ......155

12.12. Analisis Hasil Pelaksanaan Praktek Kerja

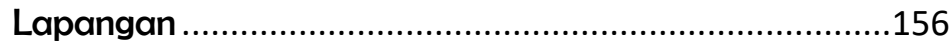

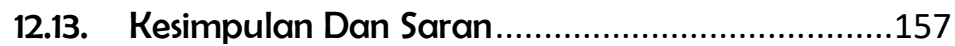

12.14. Daftar Pustaka................................................157

12.15. Lampiran - lampiran ....................................157

\section{BAB XIII CONTOH KERANGKA LAPORAN PENELITIAN} SKRIPSI /TUGAS AKHIR.............................................158

13.1. Projek Jaringan Komputer.....................................158 
13.2. Projek Pembuatan Alat (Arduino) .....................160

13.3. Projek Artificial Intellegence................................162

13.4. Projek Sistem Informasi Berbasis Objek Website 166

13.5. Projek Pemograman Animasi Kreatif.................168

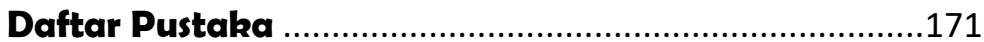




\section{BAB I PENELITIAN}

\subsection{Pentingnya Meneliti}

Manusia dalam kehidupannya, sering mengalami berbagai masalah. Dari permasalahan tersebut manusia manusia belajar menghadapi permasalahan, mencari solusi dan mencoba menyelesaikannya. Sebenarnya tanpa sadar manusia tersebut telah melakukan kegiatan meneliti. Kegiatan meneliti adalah suatu rangkaian aktivitas yang dilakukan untuk mendapatkan sebuah solusi dari permasalahan. Beberapa contoh kegiatan meneliti yang dilakukan oleh manusia tanpa disadari adalah sebagai berikut :

1. Pemilihan makanan, ketika mengunjungi sebuah rumah makan terdapat daftar menu makanan yang disediakan oleh pihak rumah makan . Ada banyak pertimbangan dalam memilih menu makanan tersebut misalnya rasanya pedas atau tidak pedas , jenisnya sayuran atau lauk dan masih banyak lagi pertimbangan. Dari banyak hal yang dipertimbangkan akhirnya diambil keputusan untuk memilih makanan berdasarkan pertimbangan. Pemilihan makanan tersebut merupakan salah satu bentuk penelitian.

2. Memilih sebuah buku, ketika seoarang mahasiswa mendapatkan tugas kuliah, mahasiswa tersebut mencari informasi terkait tugas kuliah tersebut dengan membeli buku. Ketika membeli buku , 
mahasiswa tersebut mempertimbangkan buku tersebut dengan beberapa hal yaitu kecocokan judul buku dengan tugas kuliah, daftar riwayat hidup pengarang, daftar isi buku tersebut dan sinopsis dari buku tersebut. Dari beberapa pertimbangan akhirnya mahasiswa tersebut memilih salah satu buku. Pemilihan buku tersebut merupakan suatu kegiatan meneliti.

3. Kegiatan - kegiatan lain seperti memilih sekolah lanjutan, memilih layanan hotel, memilih layanan rumah sakit, dan lain - lain . Pada dasarnya adalah bentuk - bentuk kegiatan yang dapat dikelompokkan dalam penelitian dangan pengklasfikasiannya.

Kegiatan - kegiatan diatas termasuk kegiatan penelitian yang tidak resmi atau informal. Dimana kegiatannya penelitian dan pendekatan - pendekatan yang dilakukan antara satu dengan yang lainnya berbeda. Ada yang memerlukan pertimbangan orang lain untuk mengambil keputusan atau di putuskan secara pribadi oleh pelaku tanpa campur tangan orang lain. Akibat atau resiko dari pengambilan keputusan tersebut menjadi tanggung jawab pelaku itu sendiri.

Penelitian merupakan hal yang penting bagi sebuah bangsa , ini terlihat dalam RENSTRA Kemenristek dikti 2015 - 2019 . Kemajuan sebuah bangsa dinilai dari pemanfaatan penelitian yang telah dilakukan. Bagaimana bangsa mau manfaatkan jika yang meneliti tidak ada. Untuk itu pemerintah terus - menerus mendorong 
perguruan tinggi untuk dapat melakukan penelitian sebanyak banyaknya.

Perkembangan teknologi informasi di era melenial sekarang sangat mempermudah bagi peneliti dalam melakukan penelitian. Contohnya saja penelitian dalam pengembangan sistem informasi, banyak disediakan oleh beberapa layanan yang ada di internet yang dengan mudahnya di kembangkan dan dengan biaya murah. Contohnya untuk membuat sebuat website, para developer tidak perlu membeli SQL Server atau oracle , mySQL dan PostgreSQL di tawarkan secara gratis tanpa harus membeli licence. Faktor conectivity dari internet yang semakin murah dan terjangkau oleh masyarakat indonesia . Kemudahan - kemudahan ini dapat mendorong meningkatnya volume peneliti.

Penilitian ilmiah merupakan sarana aktualisasi diri di dunia . Reputasi seorang peneliti dapat dilihat dari kuantitas dan kualitas dari publikasi ilmiah, semakin banyak dan berkualitas penelitiannya maka semakin tinggi reputasinya. Ada beberapa indikator yang dapat menentukan kuantitas dan kualitas publikasi ilmiah : Jumlah publikasi ilmiah, jumlah sitasi dari publikasi ilmiah, lembaga pengindeks publikasi ilmiah, lembaga penerbit publikasi ilmiah (Emanuel, 2017)

\subsection{Defenisi Penelitian}

Penelitian di bidang teknologi infromasi dan sistem informasi merupakan penelitian yang cepat bertumbuh karena ilmu komputer, teknologi informasi dan sistem 
informasi merupakan ilmu pengetahuan yang dinamis. Untuk dapat melakukan penelitian yang benar , diperlukan pemahaman yang kuat tentang definisi dari penelitian. Adapun beberapa definisi penelitian menurut para ahli adalah :

Research is simply the progress of finding solution to a problem after thorough study and analysis of the situasional factors (Sekaran, 2006).

Penelitian atau penyelidikan adalah suatu tindakan yang dilakukan dengan sistematika dan teliti, dengan tujuan mendapatkan pengetahuan baru atau mendapatkan susunan dan tafsiran yang baru dari pengetahuan yang telah ada, di mana sikap orang yang bertindak itu harus kritis dan prosedur yang digunakan harus lengkap (Daniel, 2002).

Penelitian adalah terjemahan dari kata "research" yang berarti usaha atau pekerjaan untuk mencari kembali yang dilakukan dengan suatu metode tertentu dan dengan cara hati-hati mencari kebenaran, memperoleh jawaban, pengembangan ilmu pengetahuan, dan sebagainya (Hasan, 2002)

Penelitian adalah proses sistematis yang meliputi pengumpulan dan analisis informasi (data) dalam rangka meningkatkan pengertian tentang fenomena yang diminati atau yang menjadi perhatian (Leedy P.D, 1997).

Dari beberapa definisi penelitian menurut para ahli diatas dapat di simpulkan bahawa penelitian adalah suatu tindakan sistematis dan terprosedur meliputi 
pengumpulan dan analisis informasi dengan menggunakan metode tertentu untuk memperoleh jawaban atau kebenaran, pengembangan ilmu pengetahuan atau meningkatkan pengertian tentang fenomena yang di teliti. Dari definisi ini dapat diambil kesimpulan bahwa kriteria penelitain ilmiah adalah :

1. Sistemtis dan terprosedur, berarti dalam penelitian terdapat rangkaian aktivitas atau kegiatan antara kegiatan satu dengan kegiatan selanjutnya memiliki tujuan yang jelas, serta dalam penelitian tersebut terdapat tahapan - tahapan yang dilalui sampai penelitian itu selesai.

2. Adanya pengumpulan data dan analisis, berarti dalam penelitian ada proses pengumpulan data atau informasi yang terkait dengan fenomena yang di teliti, kemudian dari data atau informasi tersebut diolah dan dianalisis dengan menggunakan metode atau teknik yang sudah diakui validitasnya.

3. Untuk memperoleh solusi, berarti adalah usaha untuk memperoleh solusi dari suatu permasalahan. Kesimpulan dari penelitian merupakan jawaban dari penelitian.

\subsection{Tahapan Penelitian}

Penelitian merupakan kegiatan sistematis dan terprosedur dalam memecahkan masalah atau mencari solusi dari permasalahan. Berikut adalah prosedur yang dilakukan pada saat melakukan penelitian secara ilmiah : 


\section{Langkah 1}

Menentukan topik penelitian, Latar belakang dan merumuskan masalah penelitian

\section{Langkah 2}

Mengkaji penelitian lain yang sejenis dan menemukan orisinalitas dari penelitian yang akan dilakukan dan menyusun hipotesis

\section{Langkah 3}

Membuat Desain Penelitian, Desain penelitian berfungsi sebagai rencana strategis dan prosedural yang akan menjadi penduan peneliti dalam menjawab permasalahan penelitian.

\section{Langkah 4}

Menentukan Variabel Penelitian, yang berfungsi sebagai landasan peneliti untuk mempersiapkan alat atau metode pengumpulan data untuk menguji hipotesis.

\section{Langkah 5}

Menentukan populasi dan sampel, penentuan populasi dan sampel ini berhubungan dengan data - data yang akan berkaitan dengan uji hipotesis.

\section{Langkah 6}

Mengumpulkan data, proses pengumpulan data ini terkait dengan analisis atau pengelolaan data. 


\section{Langkah 7}

Menguji Validitas dan Reliabilitas, validitas berhubungan dengan seberapa valid data tersebut sedangkan reliabilitas berhubungan dengan seberapa akurat dapat diandalkan.

\section{Langkah 8}

Menganalisis data dan mengenterpretasikan data, analisis data bertujuan untuk memperoleh gambaran manfaat dari semua data yang didapat.

\section{Langkah 9}

Temuan penelitian, tahap ini adalah tahapan peneliti menyampaikan hasil kesimpulan akhir penelitiannya.

\section{Langkah 10}

Menulis Laporan Penelitian, laporan penelitian ini berfungsi untuk mendesimilasikan penelitian yang telah dilakukan sehingga hasil penelitian dapat diketahui dan dimanfaatkan oleh orang lain .

Dalam penelitian teknologi informasi langkah - langkah ini tidak semuanya berurutan , karena dalam pengembangan teknologi informasi dapat terjadi pengulangan - pengulangan langkah atau perubahan posisi dari langkah - langkah diatas terutama dari langkah $6-10$.

\subsection{Metodologi}

Metodologi adalah kerangka kerja konseptual yang didalamnya terdapat asumsi - asumsi yang digunakan 
untuk melaksanakan penelitian. Dalam penelitian Teknologi Informasi metodologi merupakan sebuah pendekatan formal yang digunakan untuk mengimplementasikan system development life cycle (SDLC). Dalam SDLC terdapat serangkaian tahapan yang dilalui . Yang pada setiap tahapannya diperoleh output.

Beberapa kategori metodologi (Mercubuana, 2015):

Metodologi disebut process-centered apabila menekankan pada pemodelan proses sebagai inti dari konsep sistem. Disebut data-centered apabila menekankan pada pemodelan data sebagai inti dari kosep sistem. Sedangkan sebuah metodologi disebut objectoriented bila berupaya menyeimbangkan fokus bahasan baik proses dan data pada sebuah model. Metodologi Structured Design mengadopsi pendekatan tahapan formal dari SDLC yang berpindah secara logic dari satu fase ke fase berikutnya.

Berikut definisi Metodologi menurut para ahli :

Metodologi adalah sebuah pendekatan yang dibuat dalam melaksanakan, dimana didalamnya terdapat rangkaian langkah - langkah dalam melakukan penelitian dan hasilnya. (Mercubuana, 2015)

Metodologi penelitian dalam ilmu komputer atau sistem informasi atau teknologi informasi adalah kumpulan dari metode, prosedur, teknik, tool serta pendokumentasian yang membantu si peneliti dalam melaksanakan sebuah penelitian dalam bidang ilmu komputer, sistem informasi dan teknologi informasi. (Mercubuana, 2015) 
Metodologi sangat penting dalam penelitian karena metodologi akan membuat penelitian menjadi lebih terarah, dengan adanya metodologi peneliti mempunyai kerangka kerja yang dapat menjadi panduan bagi peneliti.

Mengapa perlu menggunakan metodologi dalam pengembangan sebuah sistem informasi ? (Mercubuana, 2015)

1. Mendata semua kebutuhan secara akurat

2. Memberikan metode yang sistematis dalam pengembangannya, sehingga setiap perkembangan dapat di monitor secara efektif

3. Memberikan sistem infromasi dalam waktu dan biaya yang tepat.

\subsection{Metode IImiah}

Metode ilmiah adalah cara para peneliti untuk memecahkan masalah dalam penelitiannya melalui tahapan - tahapan tertentu .Metode ilmiah berlandaskan pada pemikiran dan pengetahuan yang dialami oleh panca indera.

Metodologi berasal dari bahasa Yunani, "metodos" dan "logos" . kata "metodos" terdiri atas dua suku kata, yaitu "metha" yang berarti melalui atau melewati "hodos" yang berarti jalan atau cara. Metode berarti suatu jalan yang dilalui untuk mencapai tujuan. "logos" artinya ilmu. Metodologi adalah ilmu - ilmu atau cara yang digunakan untuk memperoleh kebenaran menggunakan penelusuran dengan cara tertentu dalam menemukan kebenaran, tergantung pada realitas yang 
sedang dikaji. Ilmu terdiri atas emapat prinsip yaitu (a) keteraturan (orde), (b) sebab-musabab (determinisme), (c) kesederhanaan (parsimoni), (d) pengalaman yang dapat diamati (empirisme). Dengan prinsip - prinsip yang demikian, maka ada banyak jalan untuk menemukan kebenaran. Metodologi adalah tata cara yang menentukan proses penelusuran apa yang akan digunakan. (Echdar, 2017)

Menurut Francis Bacon, metode ilmiah adalah serangkaian langkah - langkah berupa melakukan identifikasi masalah, mengumpulkan data dalam cakupan masalah yang ada, memilah data untuk mencari hubungan, merumuskan hipotesis atau dugaan ilmiah sementara, menguji hipotesis secara tepat dan mengonfirmasi hipotesis ilmiah apabila terdapat temuan temuan baru dalam sistematis dan berurut. (Hendry, 2005)

Menurut (Hendry, 2005), metode ilmiah merupakan salah satu cara untuk memperoleh ilmu pengetahuan. Metode ilmiah dianggap merupakan metode terbaik untuk mendapatkan pengetahuan karena metode ini menggunakan pendekatan yang sistematis, objektif , terkontrol dan dapat diuji, yang dilakukan melalui metode induktif maupun deduktif. Beberapa metode lain yang digunakan untuk memperoleh pengetahuan selain metode ilmiah adalah melalui intuisi, rasionalisme, dan empiris

Pola berfikir deduktif adalah menarik kesimpulan untuk hal yang khusus dari gejala yang umum. Sedangkan pola berfikir induktif adalah menarik kesimpulan berdasarkan yang khusus untuk hal - hal yang umum. 


\subsection{Metodologi Pengembangan Jaringan Komputer}

Network Development Life Cycle (NDLC)

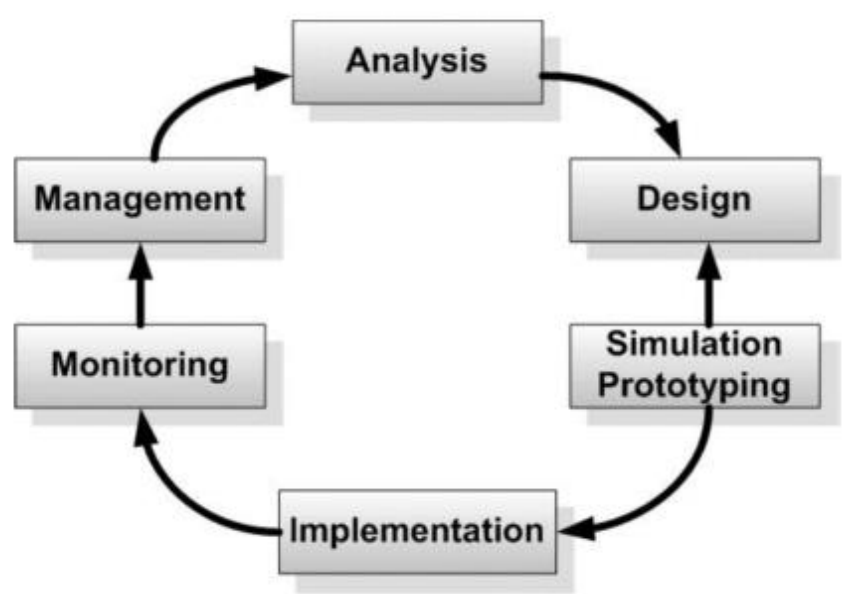

Gambar 1.1 Network Development Life Cycle (NDLC)

Pada metode NDLC terdapat tahapan - tahapan sebagai berikut (Irvan, 2017):

1. Analysis

Tahap awal ini dilakukan analisa kebutuhan, analisa permasalahan yang muncul , analisa keingan pengguna, dan analisa topologi jaringan yang sudah ada saat ini. Metode yang biasa digunakan pada tahap ini diantaranya adalah : wawancara, survei langsung atau observasi, membaca blueprint dokumentasi, kemudian dilakukan telaah terhadap setiap data yang diperoleh. Pedoman dalam melakukan tahap analisis ini adalah : 
a. User/people : jumlah user, kegiatan yang sering dilakukan, peta politik yang ada, level teknik user.

b. Media Hardware dan software : peralatan yang ada, status jaringan, ketersediaan data yang dapat diakses dari peralatan, aplikasi software yang digunakan.

c. Data : jumlah pelanggan, jumlah inventaris sistem, sistem keamanan yang sudah ada dalam mengamankan data.

d. Network : konfigurasi jarigan, volume trafik jaringan, protokol, network monitoring yang ada saat ini, harapan dna rencana pengembangan ke depan.

e. Perencanaan fisik : masalah fisik, tata letak , ruang khusus, sistem keamanan yang ada , dan kemungkinan akan pengembangan kedepan.

2. Design

Dari data - data yang telah didapat pada tahap analisis, tahap desain ini akan dibuat gambar desain topologi jaringan interkoneksi yang akan dibangun. Diharapkan dengan gambar ini akan memberikan gambaran seutuhnya dari kebutuhan yang ada. Desain bisa berupa struktur topologi, desain aksen data, desain layout pengkabelan , dan sebagainya yang akan memberikan gambaran yang jelas tentang proyek yang akan dibangun. Biaya hasil dari desain berupa :

a. Gambar - gambar topologi (server farm, firewall, datacenter, storages, lastmiles, pengkabelan, titik akses dan sebagainya). 
b. Gambar - gambar detail estimasi kebutuhan yang ada.

3. Simulation Prototype

Beberapa pekeja jaringan akan membuata bentuk simulasi dengan bentuan tools khusus di bidang netowork seperti boson, packet tracert, nestim , dan lain - lain. Hal ini dimaksudkan untuk melihat kinerja awal dari jaringan yang akan dibangun dan sebagai bahan presentasi dan sharing dengan team work lainnya.

4. Implementation

Dalam tahapan impelemntasi pekerja jaringan akan menerapkan semua yang telah direncanakan dan didesain sebelumnya. Implementasi merupakan tahapan yang sangat menentukan dari berhasi atau gagalnya proyek yang akan dibangun dan di tahap ini lah team work akan diuji dilapangan untuk menyelesaikan masalah teknik dan non teknik. Ada beberapa hal yang sering muncul pada tahap ini diantaranya :

a. Jadwal yang tidak tepat karena faktor faktor penghambat.

b. Masalah dana atau anggaran dan perubahan kebijakan

c. Team work yang tidak solid

d. Peralatan pendukung dari vendor, untuk itu dibutuhkan manajemen proyek dan manajemen resiko untuk meminimalkan sekecil mungkin hambatan - hambatan yang ada.

5. Monitoring

Setelah implementasi tahapan monitoring merupahan tahapan yang penting, agar jaringan 
komputer dan komunikasi dapat berjalan sesuai dengan keinginan dan tujuan awal dari user pada tahap awal analisis, maka perlu dilakukan kegiatan monitoring . Monitoring dilakukan dengan mengamati :

a. Infrastruktur hardware : dengan mengamati kondisi reliability atau kehandalan sistem yang telah dibangun (reliability = perfomance + availability+security).

b. Memperhatikan jalannya paket data di jaringan (pewaktuan, latency, peektime, throughtput)

c. Metode yang digunakan untuk mengamati kondisi jaringan dna komunikasi secara umum secara terpusat atau tersebar.

d. Pendekatan yang paling sering dilakukan adalah penedekatan network management. Dengan pendekatan ini banyak perangkat baik yang lokal dan tersebar dapat dimonitor secara utuh.

6. Management

Pada tahapan ini manajemen atau pengaturan merupakan salah satu yang harus diperhatikan , khususnya adalah masalah kebijakan . kebijakan perlu dibuat untuk mengatur agar sistem yang telah dibangun dapat berjalan dengan baik dan unsur reliability dapat terjaga. Kebijakan akan sangat bergantung dengan kebiajakan level manajemen dan strategi bisnis perusahaan tersebut. 


\section{Motodologi Perancangan Jaringan dengan Model PPDIOO}

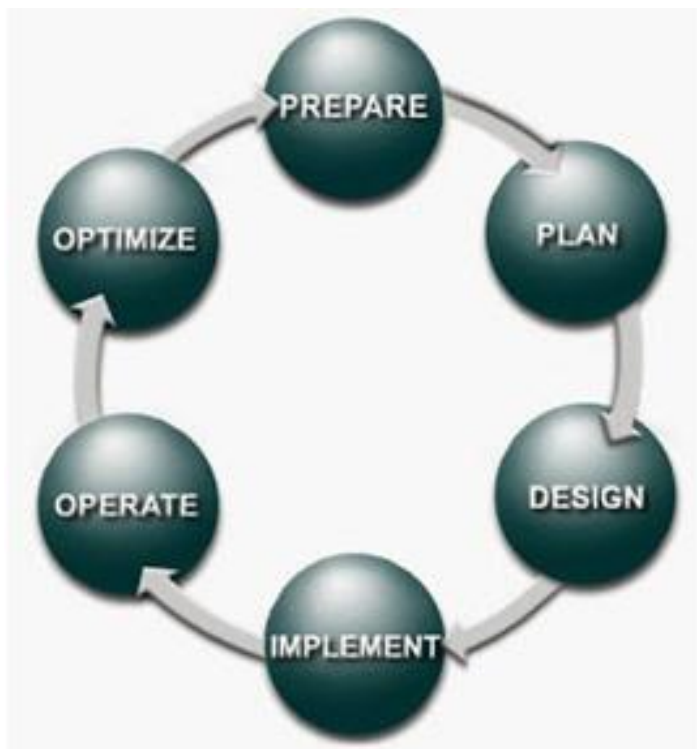

Gambar 1.2 Model PPDIOO

Model siklus hidup metode pengembangan jaringan dnegan konsep PPDIOO ini , memberikan langkah langkah kunci dalam keberhasilan perencanaan baik itu pada tahap desain, implementasi dan operasional nantinya. Pendekatan dengan model top-down design , mengarahkan infrastruktur jaringan untuk beradaptasi pada aplikasi - aplikasi apa saja yang dibutuhkan oleh suatu jaringan. Fase - fase pada PPDIOO menghasilkan beberapa manfaat diantaranya (Amin, 2013) :

a. Menurunkan total biaya yang harus dikeluarkan oleh organisasi dengan melakukan validasi persyaratan - persyaratan teknologi , perenecanan 
perubahan infrastruktur dan kebutuhan akan berbagai macam sumber daya.

b. Meningkatkan ketersediaan layanan jaringan , dengan menghasilkan desain jaringan dan melakukan validasi operasi - operasi di dalam jaringan.

c. Meningkatkan kemampuan percepatan kemajuan bisnis dengan mempersiapkan kebutuhan yang berorientasi bisnis, yang didukung oleh strategi penerapan teknologi.

d. Meningkatkan kecepatan akses ke aplikasi aplikasi dan layanan dengan meningkatkan keandalan, ketersediaan, keamanan, skalabilitas dan kinerja.

Berikut adalah pemahaman detail mengenai tiap - tiap fase pada metode pengembangan jaringan PPDIOO adalah sebagai berikut :

a. Fase Prepare (persiapan)

Fase prepare menetapkan kebutuhan organisasi dan bisnis, mengembangkan strategi jarinan dan mengusulkan konsep arsitektur dengan level tingkat tinggi, untuk mendukung suatu strategi, yang didukung dengan kemampuan keuangan pada organisasi atau perusahaan tersebut.

b. Fase Plan (perencanaan )

Fase plan mengidentifikasi persyaratan jaringan berdasarkan tujuan, fasilitas dan kebutuhan pengguna. Fase ini mendeskripsikan karakteristik suatu jaringan yang bertujuan untuk menilai jaringan tersebut, melakukan gap analissi pada perancangan terbaik sebuah arsitektr, dengan melihat perilaku dari lingkungan operasional. Sebuah perencanaan proyek dikembangkan untuk 
mengelola tugas - tugas , pihak - pihak yang bertanggung jawab, milestone dan semua sumber daya untuk melakukan desain dan implementasi. Perencanaan proyek harus sejalan dengan ruang lingkup, biaya dan parameter sumber daya yang disesuaikan dengan kebutuhan bisnis. Rencana proyek ini diikuti dan diperbaharui selama fase fase dalam siklus.

c. Fase Design (Desain)

Desain jaringan dikembangkan berdasarkan persyaratan teknis dan bisnis yang diperoleh dari kondisi sebelumnya. Spesifikasi desain jaraingan adalah desain yang bersifat komprehensif dan terperinci, yang memenuhi persyaratan teknis dan bisnis saat ini. Jaringan tersebut haruslah menyediakan ketersediaan, kehandalan , keamanan , skalabilitas dan kinerja. Hasil desain diagram jaringan dan daftar peralatan - peralatan . Rencana proyek harus terus diperbaharui, dengan informasi yang lebih terperinci untuk diimplementasikan . setelah tahap desai disetujui, fase implementasi dimulai.

d. Fase Implement(Impelementasi)

Pada fase ini, peralatan - peralatan baru dilakukan instalasi dan di konfigurasi, sesuai spesifikasi desain. Perangkat - perangkat baru ini akan menggati atau menambahkan infrastruktur yang ada. Perencanaan proyek juga arus diikuti selama fase ini, jika ada perubahan seharusnya disampaikan dalam pertemuan dengan persetuan yang diperlukan untuk dilanjutkan. Setiap langkah dalam implementasi harus menyertakan deskripsi , rincian pedoman pelaksanaan, perkiraan waktu 
untuk penerapan, evaluasi (rollback) langkah langkah jika terdapat kegagalan , dan informasi informasi lainnya sebagai referensi tembahan. Seiring perubahan yang telah diimplementasikan , tahapan ini juga menjadi langkah pengujian , sebelum pindah ke fase operasional

e. Fase Operate (Operasional)

Fase operasional ini adalah mempertahankan ketahanan sehari - hari jaringan. Operasional meliputi pengelolaan dan memonitor komponen komponen jaringan , pemeliharaan routing, mengelola kegitan upgrade, mengelola kinerja , mengidentifikasi dan mengoreksi kesalahan jaringan. Tahapan ini adalah ujian akhir bagi tahap desain . Selama operasi , manajemen jaringan harus memantau stabilitas dan kinerja jaringan, deteksi kesalahan, koreksi konfigurasi dan kegiatan kegiatan pemantauan kinerja, yang menyediakan data awal untuk fase selanjutnya.

f. Fase Optimize (Optimalisasi)

Fase optimalisasi melibatkan kesadaran proaktif seoarang manajemen jaringan dengan mengidentifikasi dan menyelesaikan masalah, sebelum persoalan tersebut mempengaruhi jaringan. Fase optimalisasi, memungkinkan untuk memodifikasi desain jaringan, jika terlalu banyak masalah jaringan yang timbul, kemudian juga untuk memperbaiki masalah kinerja atau untuk menyelesaikan masalah - masalah pada aplikasi. Persyaratan untuk desain jaringan yang dimodifikasi mengarahkan perkembangan jaringan tersbeut, kembali ke awal siklus kehidupan model fase PPDIOO. 


\subsection{Metodologi Pengembangan Sistem Informasi}

Dalam merancang sistem informasi terdapat tahapan pengumpulan requirement sistem, requirement sistem tersebut digunakan sebagai bahan untuk analisis dan medesain sistem. Metodologi berperan dalam proses pendokumentasian requirement sistem tersebut sehingga penelitian menjadi lebih detail dan lebih teliti. Metodologi juga memberikaan sebuah gagasan untuk pengembangan sistem sehingga track record nya dapat termonitor. Sehingga progres yang dicapai dapat terlihat.

Dalam perancangan atau pengembangan sistem informasi , terdapat beberapa metodologi yang sudah dikenal, seperti :

\subsubsection{Generik}

model proses generik yang memiliki 5 aktivitas kerangka kerja dan ditunjang dengan sejumlah aktivitas - akivitas pendukung. Pada dasarnya proses dari rekayasa perangkat lunak dapat menjadi sebuah aliran proses yang masing - masing memiliki urutan akivitas kerja yang berbeda - beda disesuaikan berdasarkan lingkup proyeknya , Pressman menggambarkan pada model proses generik terdapat empat aliran proses . (Roger S. Pressman, 2012)

a. Linier

Pada model proses linier terdapat aliran aktivitas kerja sebagai berikut : 


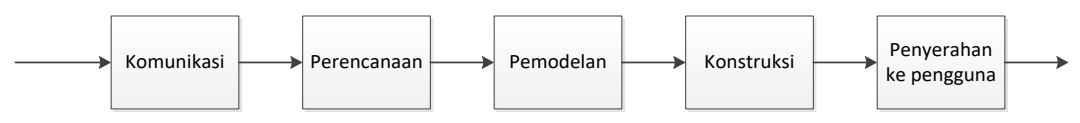

Gambar 1.3 Model proses linier

b. Iteratif

Pada model proses iteratif terdapat aliran aktivitas kerja sebagai berikut :

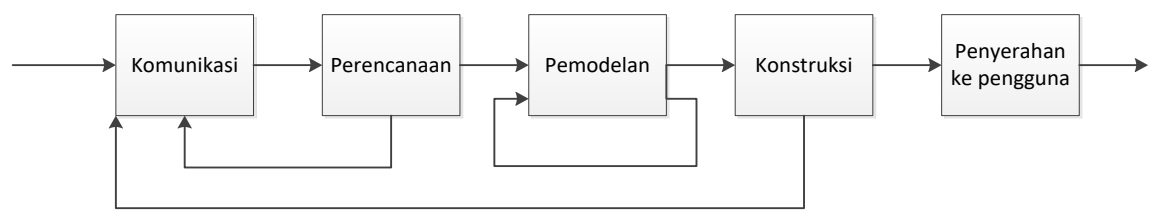

Gambar 1.4 Model proses iteratif

c. Evolusioner

Pada model proses evolusioner terdapat aliran aktivitas kerja sebagai berikut :

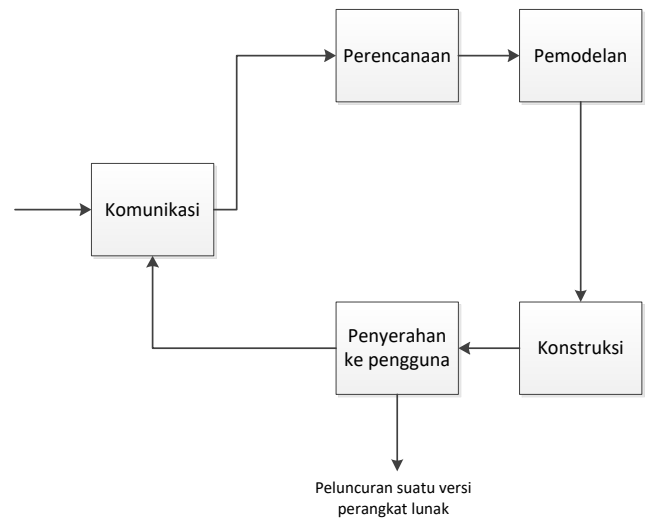


Gambar 1.5 Model Proses Evolusioner

d. Paralel

Pada model proses paralel terdapat aliran aktivitas kerja sebagai berikut :

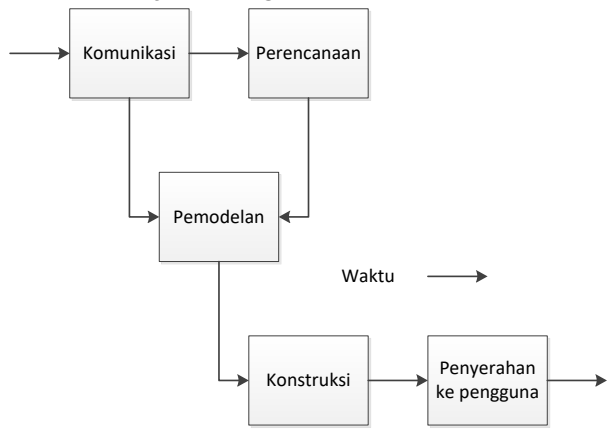

Gambar 1.6 Model Proses Paralel

\subsubsection{Perspektif}

a. Waterfall

Pressman mengemukakan bahwa model air terjun ini menyiratkan pendekatan yang sistematis dan berurutan pada perangkat lunak yang dimulai dari perencanaan (planning), pemodelan(modeling), konstruksi(construction), serta penyerahan perangkat lunak kepada pelanggan (deployment) , yang diakhiri dengan dukungan berkelanjutan pada perangkat lunak lengkap yang dihasilkan . Model air terjun ini dapat digambarkan sebagai berikut (Roger S. Pressman, 2012): 


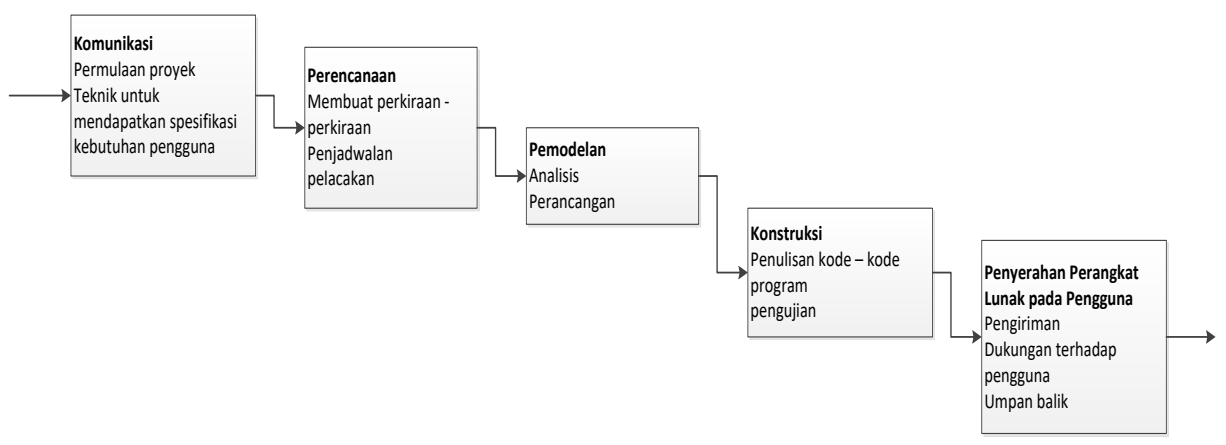

Gambar 1.7 Model Proses Waterfall

b. Inkremental

Model inkremental atau disebut dengan model penambahan sedikit demi sedikit ini menggabungkan elemen - elemen aliran proses dari model generik yaitu aliran proses linier dan aliran proses paralel (Roger S. Pressman, 2012). Masing - masing urutan linier menghasilkan bagian penambahan dari perangkat lunak dengan cara serupa dengan penambahan sedikit demi sedikit yang dihasilkan oleh suatu aliran proses yang bersifat evolusioner. Contohnya adalah perangkat lunak pengolah kata yang dikembangkan dengan cara penambahan sedikit demi sedikit dengan menambahkan fungsi - fungsi pengelolaan berkas, penyuntingan dan fungsi - fungsi dokumen yang dibuat pada tahap pertama, kemudian fungsi penyuntingan dan fungsi produksi 
yang lebih canggih pada tahap kedua. Pada setiap aliran proses setiap penambahan dapat digabungkan dengan pembentukan prototipe. Produk yang dihasilkan pada tahap pertama merupakan produk inti, produk yang dihasilkan pada tahap kedua dan selanjutnya merupakan fitur - fitur tambahan yang merupakan pengembangan dari produk tersebut. Model inkremental digambarkan sebagai berikut :

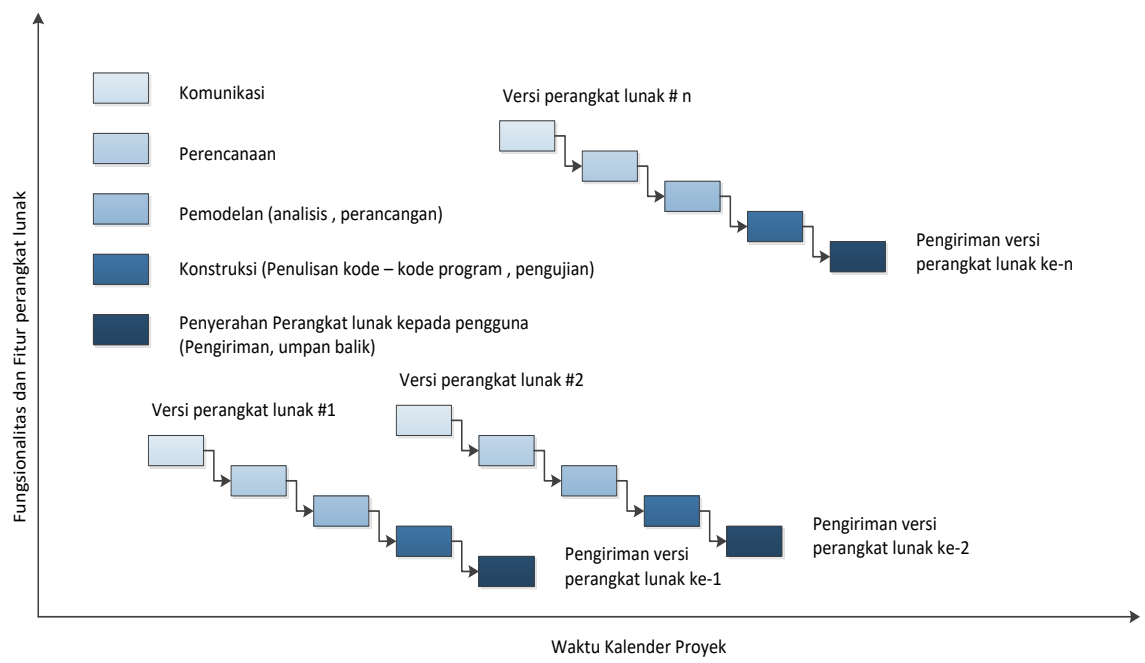

Gambar 1.8 Model Proses Inkremental

c. Evolusioner

Model proses evolusioner adalah model proses perangkat lunak yang dirancang untuk mengakomodasi suatu produk perangkat 
lunak yang akan berubah secara perlahan sepanjang waktu. Model proses evolusioner ini digunakan untuk menjawab tantangan perubahan kebutuhan perangkat lunak yang semakin kompleks. Model proses evolusioner ini bersifat iteratif yang dicirikan dalam bentuk yang memungkinkan pengembang perangkat lunak untuk mengembangkan produknya menjadi semakin kompleks pada versi - versi berikutnya. Model proses evolusioner ini terbagi menjadi beberapa paradigma pendekatan yaitu :

1. Prototipe

Paradigma pembuatan prototipe seringkali membantu tim pengembang perangkat lunak dan para stakeholder untuk memahami kebutuhan perangkat lunak yang akan dikembangkan.

Pembuatan protipe dimulai dengan dilakukannya komunikasi antara tim pengembang perangkat lunak dengan pelanggan, kemudian menetapkan sasaran pengembangan secara keseluruhan dan mengidentifikasi spesifikasi kebutuhan. Pembuatan prototipe direncanakan dan dirancang dengan cepat. Rancangan kemudian di kontruksi untuk membuat prototipe. 
Prototipe kemudian diserahkan kepada stakeholder dan mereka melakukan evaluasi terhadap prototipe tersebut, yang pada akhirnya memberikan umpan balik yang akan digunakan untuk memperbaiki atau mengembangkan spesifikasi kebutuhan perangkat lunak. Pengulangan yang terjadi pada saat prototipe diperbaiki secara tidak langsung memenuhi kebutuhan stakeholder, dan pada saat yang sama memungkinkan pengembang memahami lebih dalam kebutuhan dari perangkat lunak yang dikerjakan. Semakin banyak pengembangan maka perangkat lunak berevolusi memenuhi kebutuhan pengguna. Paradigma pembuatan prototipe digambarkan sebagai berikut : 


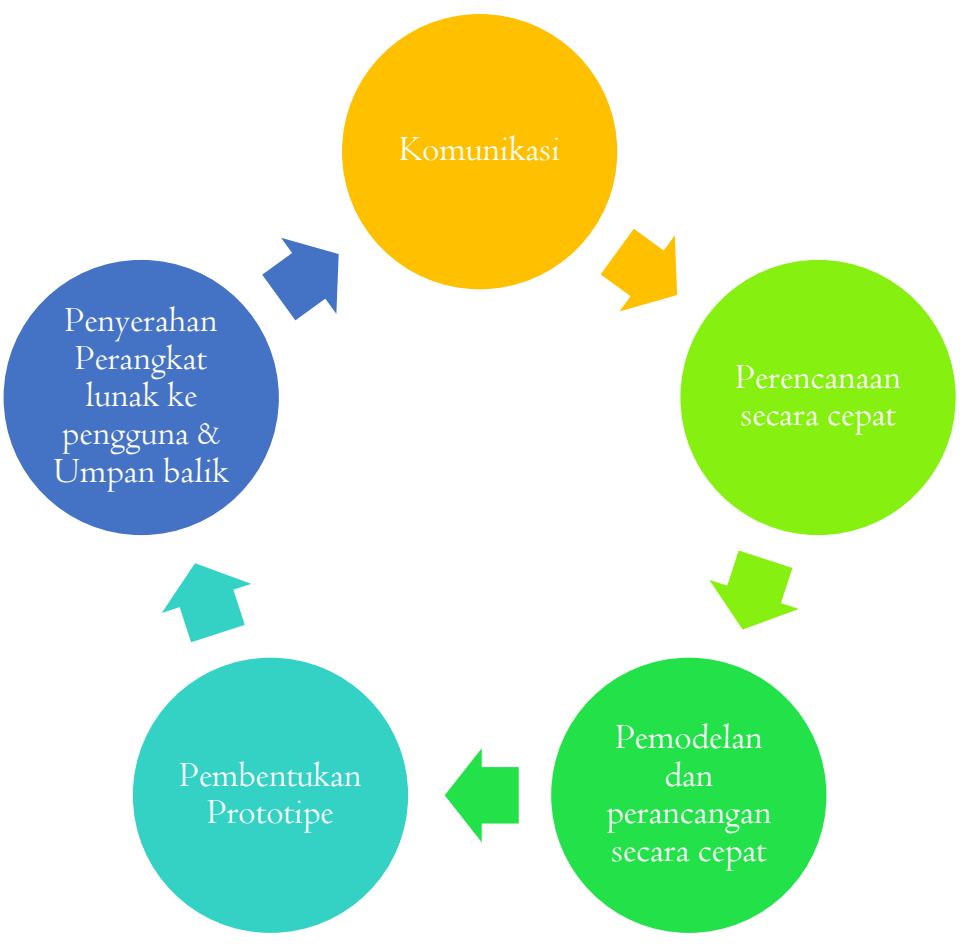

Gambar 1.9 Model Proses Prototipe

2. Spiral

Model spiral merupakan suatu model proses perangkat lunak evolusioner yang menggabungkan pendekatan prototyping yang bersifat iteratif dengan aspek - aspek sistematis dan terkendali yang di jumpai pada model 
air terjun. Menggunakan model spiral , perangkat lunak dikembangkan mengikuti peluncuran produk yang bersifat evolusioner. Selama tahap awal, produk perangkat lunak yang di luncurkan mungkin berupa sebuah model atau suatu prototipe. Pada langkah - langkah iterasi berikutnya versi - versi perangkat lunak yang semakin lengkap akan dihasilkan (Roger S. Pressman, 2012).

Model pengembangan spiral dimulai dengan fase perencanaan, yang mengevaluasi elemen kerja utama dari proyek seperti tujuan, kondisi pasar dan banyak lagi. Fase berikutnya, analisis risiko mencoba memecahkan masalah dalam lebih dari satu cara. Fase ketiga adalah menyelesaikan pekerjaan, diikuti oleh ulasan pelanggan yang bergantung pada umpan balik dari pelanggan. Iterasi berhenti ketika penyampaian akhir dikembangkan. Dengan cara ini baik klien dan tim pengembangan berinteraksi secara berkala, meningkatkan produk yang dapat dikirimkan satu per satu (Receptives, 2018). Berikut gambar model spiral : 


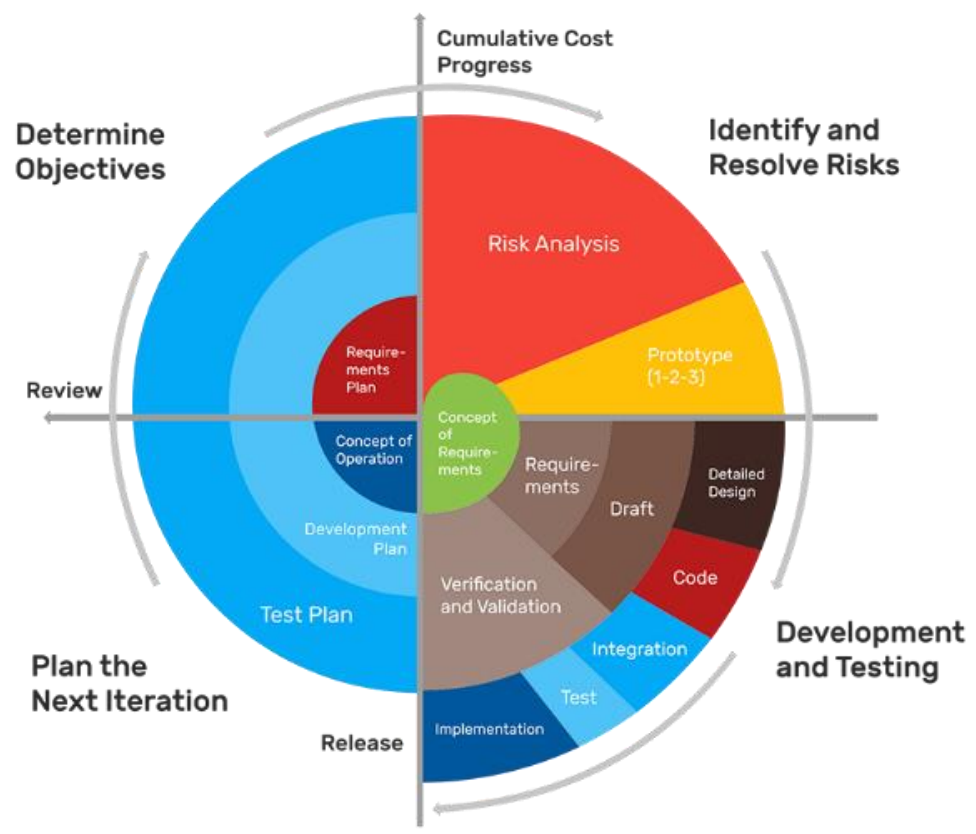

Gambar 1.10 Model Proses Spiral

3. Konkuren

Model pengembangan perangkat lunak konkuren, memungkinkan tim perangkat lunak untuk menggunakan unsur - unsur yang bersifat berulang atau iteratif dan konkuren atau berjalan bersamaan dalam setiap model proses. Berikut gambaran aktivitas model konkuren (Roger S. Pressman, 2012). 


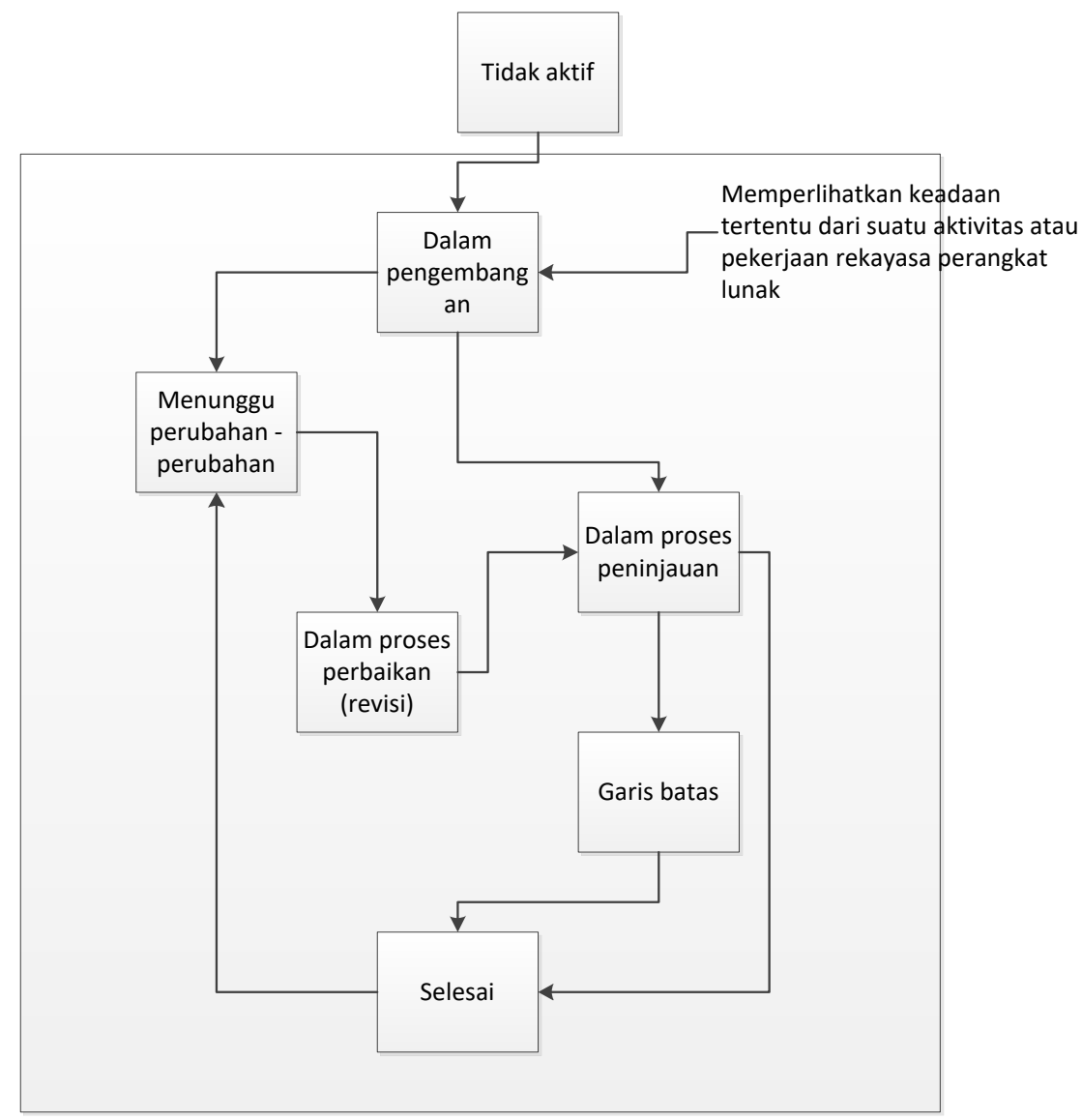

Gambar 1.11 Model Proses Konkuren

d. Unified Process

Proses terpadu (unified process) berusaha menggunakan karakteristik - karakteristik 
terbaik model proses perangkat lunak tradisional, tetapi menggabungkannya dengan prinsip - prinsip terbaik yang dimiliki pengembang perangkat lunak yang cepat. Proses terpadu mengenali pentingnya komukasi dengan para pelanggan dan menekankan deskripsi sistem dari sudut pandang pelanggan (melalui diagram diagram usecase).

Tahapan dari proses terpadu adalah sebagai berikut (Roger S. Pressman, 2012) :

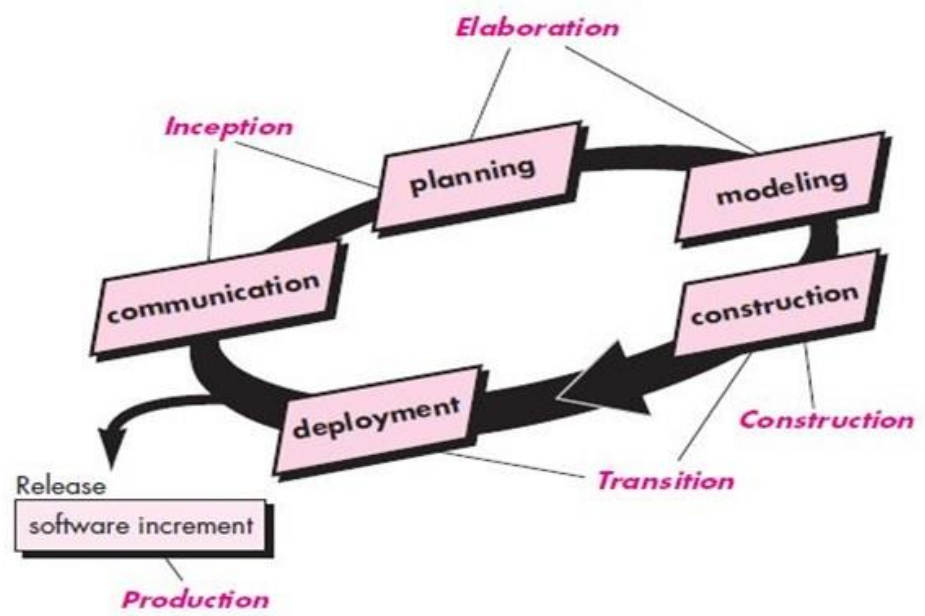

Gambar 1.12 Model Proses Terpadu

\subsubsection{Agile Methods}

a. Pemograman Extreme

Pemograman Extrem(Extreme Programming)

yaitu suatu pendekatan yang paling banyak 
digunakan untuk pengembangan perangkat lunak cepat. Nilai - nilai yang membentuk dasar dari XP adalah komunikasi, kesederhanaan, umpan balik, keberanian dan rasa hormat.

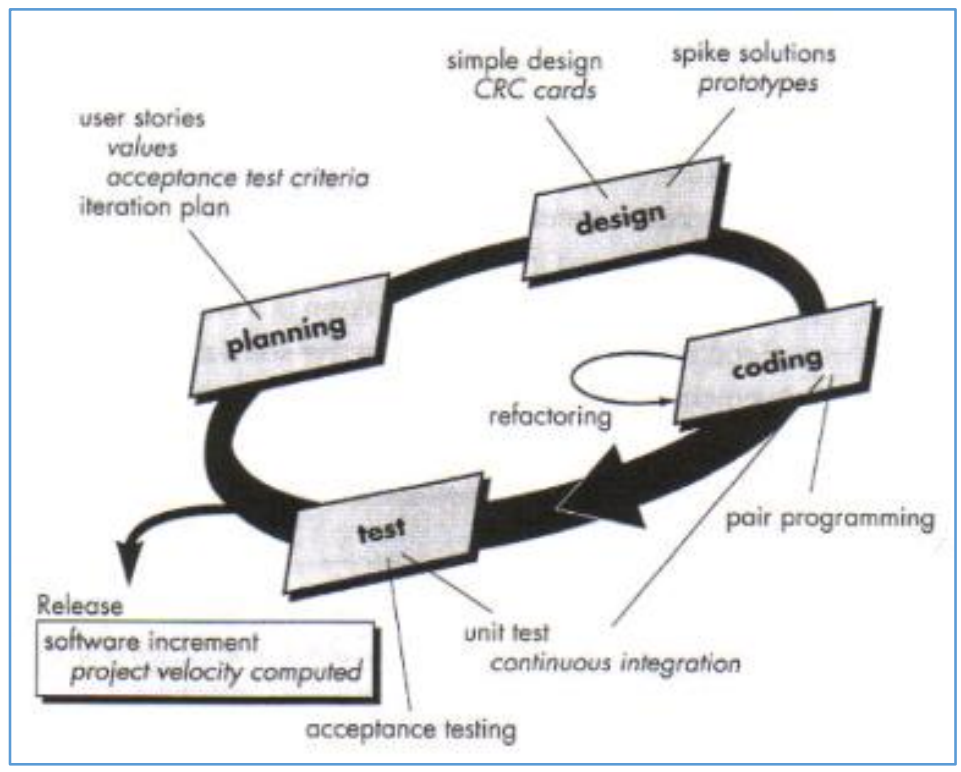

Gambar 1.13 Model Proses Agile

b. Adaptive Software Development

Fokus dari ASD adalah kolaborasi manusia. Siklus hidup ASD menggabungkan tiga fase yaitu spekulasi, kolaborasi dan pembelajaran.

Spekulasi proyek dimulai dan perencanaan siklus adaptif dilakukan . siklus perencanaan adaptif menggunakan informasi inisiasi 
proyek yaitu pernyataan misi pelanggan, kendala proyek dan kebutuhan dasar yang akan dibutuhkan untuk proyek tersebut. Orang - orang yang termotivasi akan melakukan kolaborasi sehingga dapat meningkatkan kinerja. Kolaborasi ini meliputi komunikasi, kerjasama , menekan individulaisme sehingga akan menciptakan kepercayaan antar anggota tim. Penekanan dari pengembangan komponen siklus adaptif adalah pembelajaran, pembelajaran akan membantu pemahaman anggota tim.

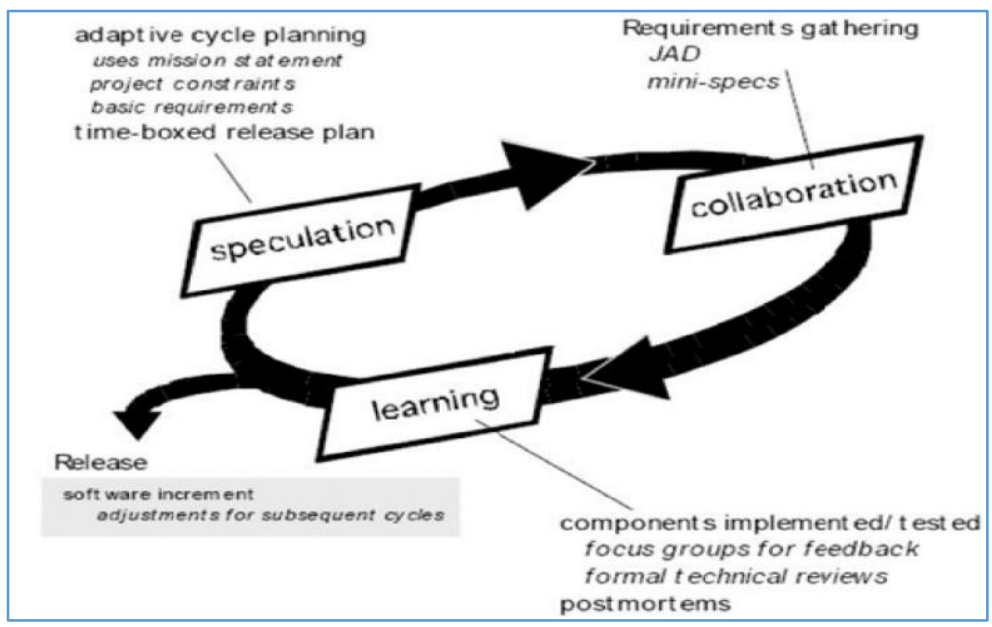

Gambar 1.14 Model Proses Adaptive Software

Development 


\section{c. Scrum}

Scrum merupakan suatu metode pengembangan perangkat lunak yang proses pengembangannya mencakup kegiatan kerangka kerja berikut : kebutuhan, analisis, perancangan, evolusi dan penghantaran. Dalam masing - masing kegiatan kerangka kerja , tugas kerja terjadi dalam suatu pola proses yang disebut sebagai sprint. Kerja yang dilakukan dalam suatu sprint disesuaikan dengan masalah yang dihadapi dan didefinisikan dan seiring dirubahn secara real time oleh tim scrum (Roger S. Pressman, 2012). Berikut adalah aliran proses scrum (Maxxor, 2018):

\section{SCRUMM SORTWARE PROCESS}

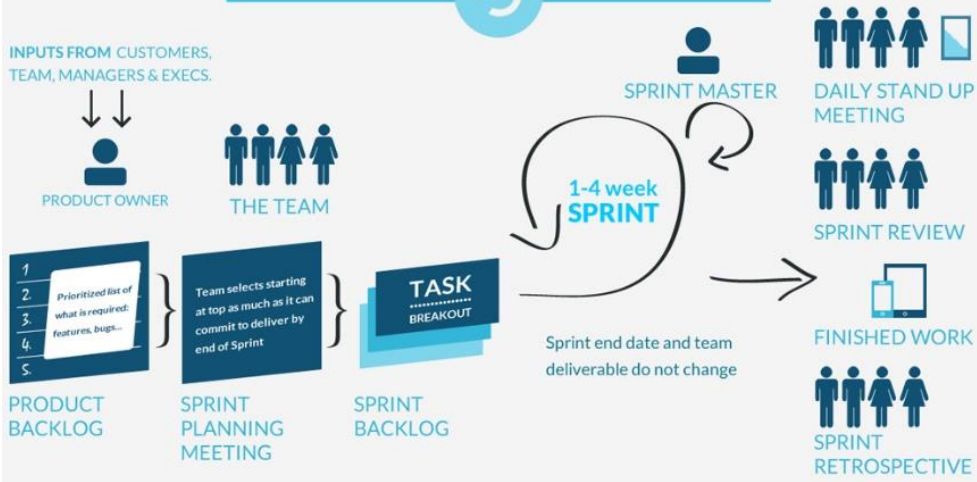

Gambar 1.15 Model Proses Scrum 
d. Dynamic System Development Methode Merupakan sebuah pendekatan pengembangan perangkat lunak cepat yang menyediakan kerangka kerja untuk membangun dan memelihara sistem yang memenuhi batas waktu yang ketat melalui penggunaan protipe yang secara perlahan ditambahi dan diperluas dalam lingkungan proyek terkendali. Siklus hidup dari DSDM ini meliputi :

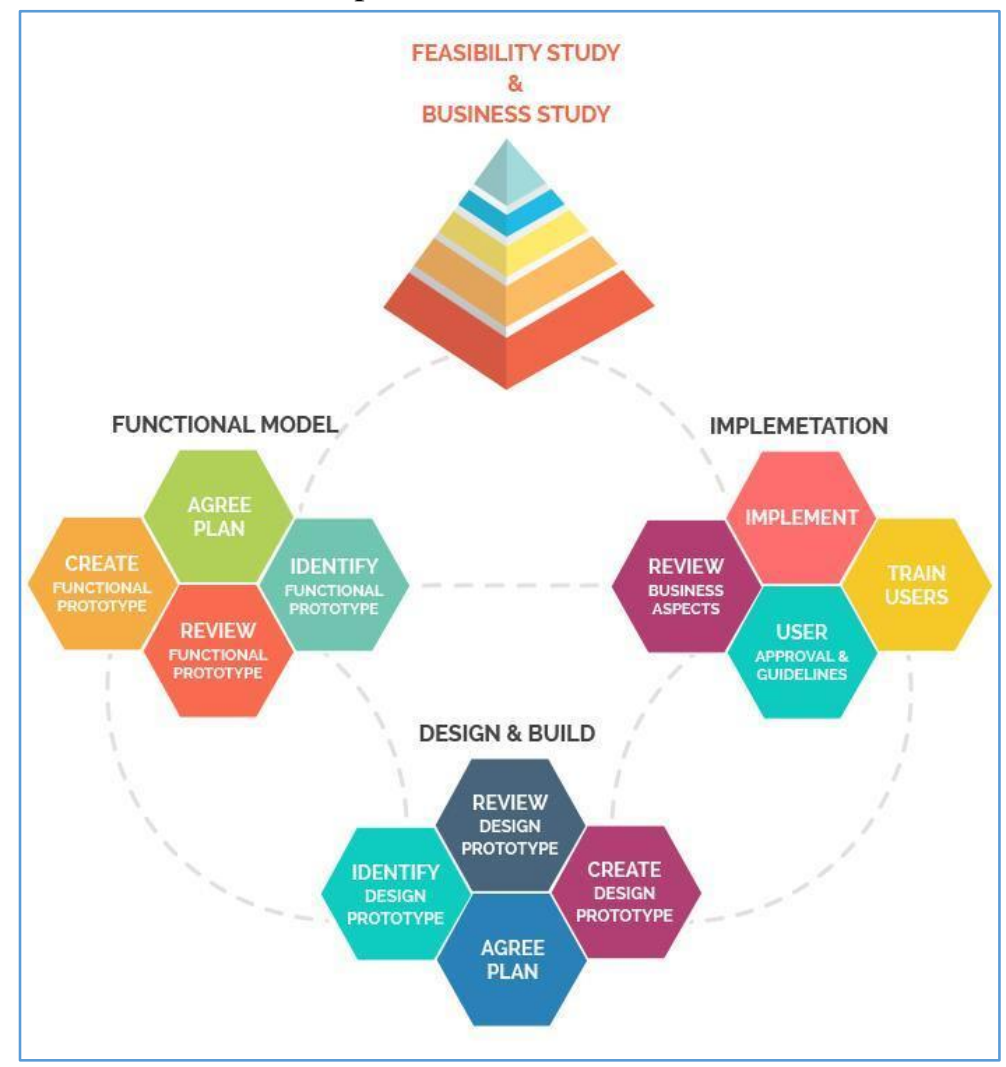


Gambar 1.16 Model Proses Dynamic System Development Methode

e. Feature Driven Developement

Tujuan utama FDD adalah menyampaikan perangkat lunak yang nyata dan bekerja secara berulang pada waktu yang tepat. Keuntungan menggunakan FDD adalah scalable bahkan untuk tim besar karena konsep 'just enough design first' (JEDI). Ini adalah solusi yang bagus untuk mempertahankan kendali atas proyek yang lincah, inkremental dan inheren kompleks karena prosesnya yang berpusat pada fitur. Ini digunakan dalam proyek-proyek perusahaan serta proyek web seperti situs game online Mousebraker.com (SANTOS, 2017). 


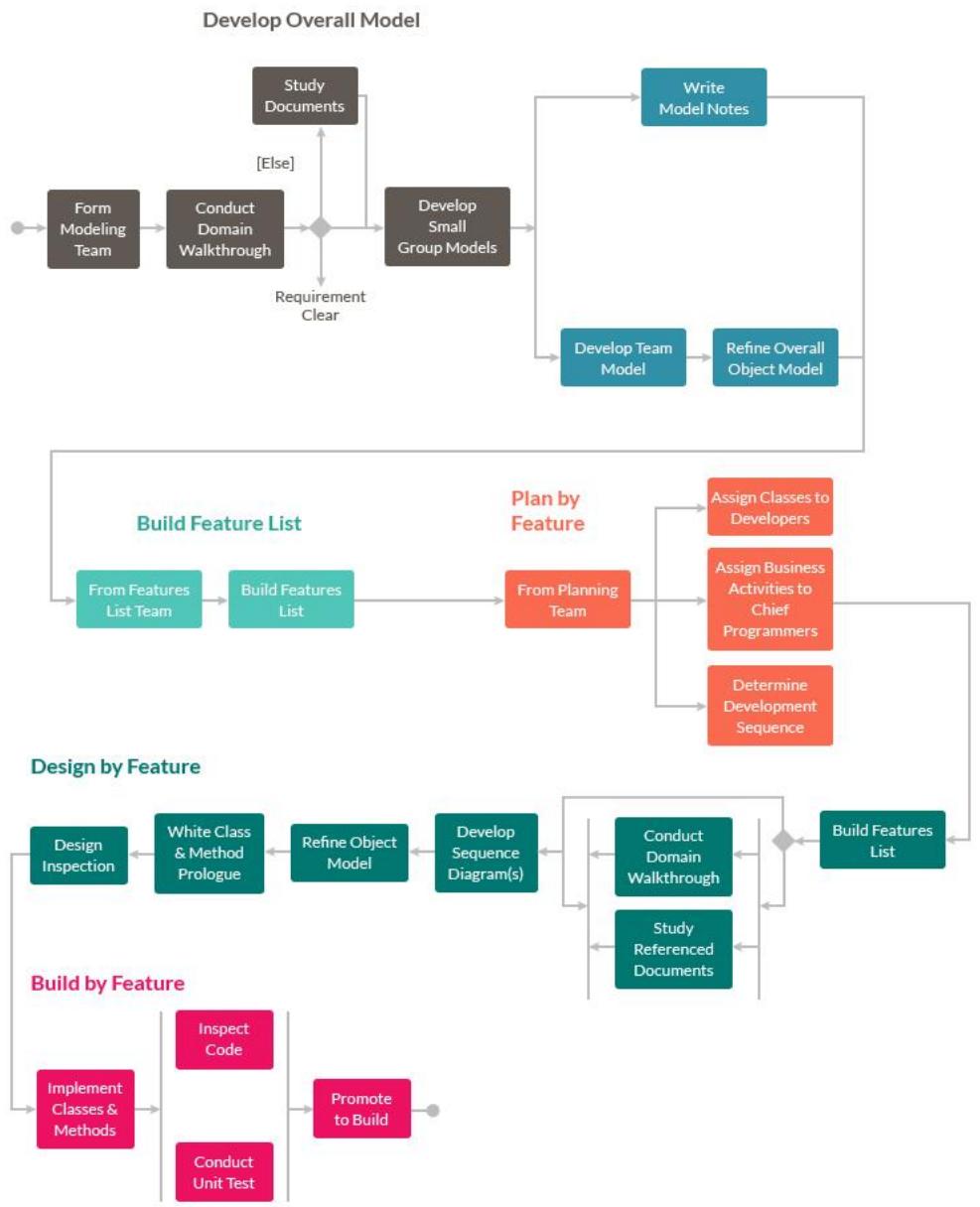

Gambar 1.17 Model Proses Feature Driven

Developement

f. Lean Software Development

berfokus pada penciptaan perangkat lunak yang mudah berubah. Model Pengembangan Perangkat Lunak ini lebih strategis daripada berbagai jenis 
metodologi tangkas lainnya. Tujuan dari metodologi ini adalah untuk mengembangkan perangkat lunak dalam sepertiga waktu, dengan anggaran yang sangat terbatas, dan jumlah alur kerja yang sangat sedikit (tatvasoft, 2015).

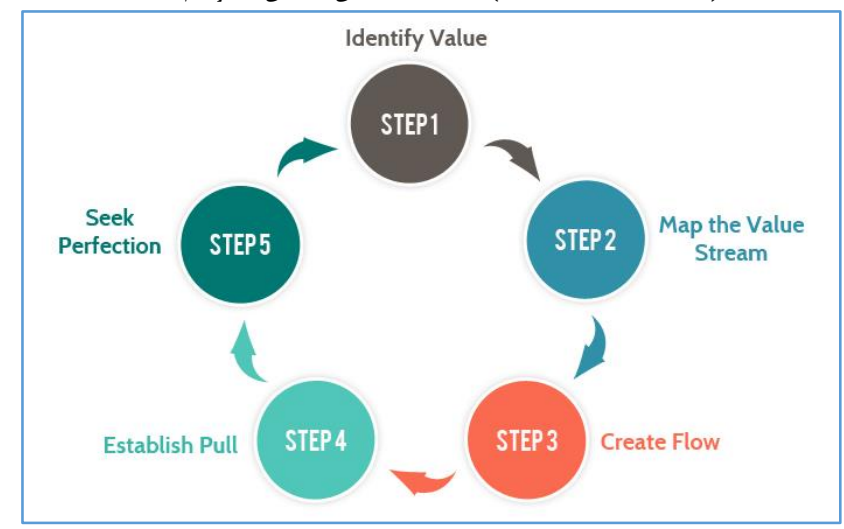

Gambar 1.18 Model Proses Lean Software Development

g. Agile Unified Process

AUP merupakan pendekatan yang menyediakan suatu susunan yang bersifat serial yaitu urutan linier dari kegiatan rekayasa perangkat lunak yang memungkinkan sebuah tim perangkat lunak memvisualkan keseluruhan aliran proses untuk sebuah model perangkat lunak. , namun dalam setiap kegiatan, tim berulang untuk mencapai kecepatan dan untuk memberikan peningkatan perangkat lunak 
yang berarti kepada pengguna akhir secepat mungkin.

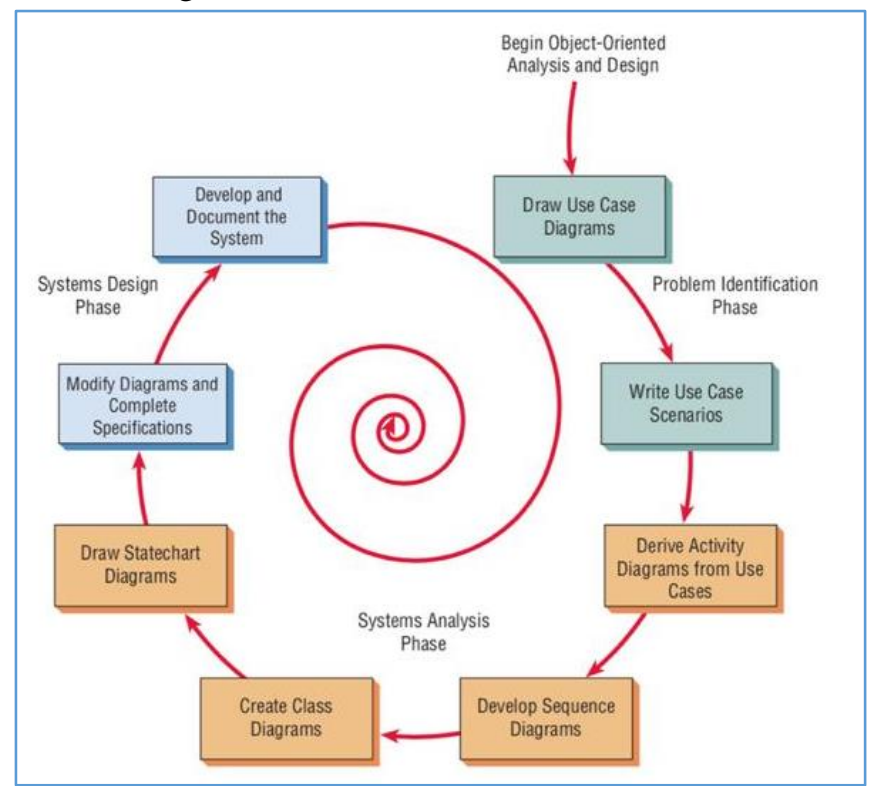

Gambar 1.19 Model Proses Agile Unified Process

\subsection{Klasifikasi Penelitian}

Berikut diuraikan klasifikasi penelitian :

\section{Klasifikasi penelitian menurut tujuan}

Penelitian, berdasarkan tujuannya terbagi menjadi penelitian dasar dan penelitian terapan. Penelitian dasar (basic research) merupakan penelitian murni yang meliputi pengembangan ilmu pengetahuan. Penelitian murni biasanya dilakukan untuk menguji 
kebenaran sebuah teori tertentu atau mengetahui sebuah konsep secara mendalam.

Sedangkan penelitian terapan (action research) merupakan penelilitian yang terkait dengan pengaplikasian teori untuk memecahkan permasalahan tertentu. Contoh peneltian terapan

a. Penelitian Evaluasi

Penelitian evaluasi (evaluation research) adalah penelitian yang memiliki tujuan untuk memberikan masukan atau dukungan pengambilan keputusan tentang dua atau lebih alternatif tindakan.

b. Penelitian dan Pengembangan

Penelitian dan pengembangan (research and development) merupakan penelitian yang bertujuan untuk mengembangkan sebuah produk sehingga produk yang dihasilkan tersebut memiliki nilai atau berkualitas tinggi

c. Penelitian Tindakan

Penelitian tindakan (action research) adalah penelitian yang dilakukan bertujuan untuk segera dipergunakan sebagai dasar tindakan pemecahan masalah.

\section{Klasifikasi Penelitian Menurut Metode}

Klasifikasi penelitian menurut metode dapat terbagi menjadi :

a. Penelitian Historis

Penelitian historis adalah penelitian yang bertujuan untuk mendapatkan sebuah 
kesimpulan mengenai sebab-sebab, dampak, atau perkembangan dari kejadian yang lalu yang digunakan untuk menjelaskan kejadian sekarang dan untuk mengantisipasi kejadian di masa yang akan datang. Penelitian ini meliputi penyelidikan, pemahaman dan penjelasan tentang kejadian yang telah lalu. Dalam penelitian historis ini menggunakan sumber data primer maupun sekunder. Contoh penelitian historis : perkembangan sistem informasi di segala bidang , perkembangan metodologi pengembangan sistem informasi , dll

\section{b. Penelitian deskriptif}

Penelitian deskriptif adalah penelitian yang meliputi kegiatan pengumpulan data yang kemudian data tersebut di uji untuk dapat menjawab pertanyaan dari status terakhir objek penelitian. Tipe dari penelitian ini meliputi penilaian organisasi, penilaian prosedur, penilaian keadaan, dll. Penelitian deskriptif berusaha untuk memperoleh deskripsi penjelasan yang lengkap dan akurat - Kelemahan dari penelitian deskriptif ini adalah kurang adanya tanggapan subyek penelitian. Sehingga kecerobohan subyek penelitian dalam proses pengumpulan data maka kesimpulan yang benar tidak dapat ditemukan. Contoh penelitian deskriptif : 
1) Bagaimana kepuasan mahasiswa terhadap pelayanan kampus

2) Bagaimana tanggapan mahasiswa terhadap sistem pembelajaran yang diberikan dosen.

3. Klasifikasi penelitian menurut bentuk ilmunya (Trochim, 2006)

Menurut bentuk ilmunya penelitian terbagi menjadi

a. Penelitian induktif adalah penelitian yang meneliti kasus - kasus yang spesifik dan kemudian berusaha untuk mendapatkan generalisasinya yang dapat diterapkan untuk bidang atau hal yang lebih besar atau yang disebut dengan pendekatan bawah ke atas (bottom-up). Penelitian induktif yang berhasil bisa melahirkan teorema, metode, ataupun teknik -teknik baru yang berlaku dalam lingkup yang lebih besar yang berasal dari kasus - kasus spesifik yang telah dipelajari.

b. Penelitian deduktif adalah penelitian yang berdasarkan metode atau teorema yang telah diketahui dan di teliti untuk diterapkan ke suatu kasus atau data yang belum diketahui atau sering disebut pendekatan dari atas ke bawah (top-down). Penelitian deduktif berguna untuk menguji atau metode sebelumnya telah diketahui apakah berlaku untuk kasus - kasus spesifik yang dijadikan fokus penelitin. 


\section{Klasifikasi penelitian menurut bentuk datanya}

(UKEssays, 2013)

Penelitian merut bentuk datanya terbagi menjadi :

a. Penelitian kuantitatif adalah penelitian yang data utamanya merupakan data - data yang berupa angka yang dapat diolah secara matematis. Hasil analisis dari data - data kuantitatif ini kemudian dijadikan dasar untuk mengambil suatu kesimpulan yang diharapkan dapat menjadi solusi dari permasalahan yang diteliti.

b. Penelitian kualitatif adalah penelitian yang data utamanya merupakan data - data yang berupa bukan angka, misalnya hasil survey, opini, dan lain - lainnya. Data - data yang bukan berupa angka ini dapat juga dipresentasikan menjadi angka yang kemudian dapat diolah secara matematis untuk kemudian diambil suatu kesimpulan yang seharusnya merupakan solusi dari permasalahan yang diteliti.

Khusus penelitian untuk bidang Teknologi Informasi termasuk dalam kategori (Emanuel, 2017) :

a. Penelitian Terapan

Penelitian yang bertujuan untuk menyelesaikan masalah yang dihadapi oleh 
manajer perusahaan secara mendesak disebut penelitian terapan (applied research) (Sekaran, 2006)

b. Penelitian Induktif ataupun Deduktif

c. Penelitian kuantitatif ataupun kualitatif

Jika kita menggacu pada metodologi yang digunakan pada pengembangan sistem informasi maka penelitian yang dilakukan termasuk dalam Research and development(RND).

RND merupakan suatu proses atau langkah - langkah untuk mengembangkan suatu produk baru atau menyempurnakan produk yang telah ada dan dapat dipertanggung jawabkan. Produk dapat berupa perangkat keras maupun perangkat lunak. langkah - langkah yang terdapat dalam RND meliputi tahap potensi dan masalah , pengumpulan data, desain produk, validasi desain, revisi desain produk, uji coba produk, revisi produk, uji coba pemakaian, revisi produk dan produksi masala.

\subsection{Proposal Penelitian}

Dalam penelitian Teknologi Informasi tentunya membutuhkan biaya untuk melakukan penelitiannya. Beberapa organisasi menyediakan dana untuk pelaksanaan penelitian contohnya Kementrian Ristek Dikti memberikan dana untuk pelaksanaan penelitian. Tentunya untuk dapat mendaftar, peneliti perlu menyajikan gagasan penelitiannya ke dalam sebuah proposal. Agar dapat lulus seleksi maka proposal perlu disusun dengan baik dan meyakinkan agar memiliki 
peluang untuk mendapatkan dana penelitian. Setiap organisasi atau lembaga memiliki ketentuan - ketentuan tersendiri terkait dengan format dari proposal penelitian. Pada umumnya , terdapat poin - poin yang biasanya di cantumkan dalam proposal penelitian adalah (Emanuel, 2017):

1. Judul

Judul bersifat singkat dan padat, disarankan untuk tidak lebih dari 14 (empat belas) kata.

2. Latar belakang dan perumusan masalah

Penyusunan latar belakang diawali dari berbagai hal yang bersifat global yang diketahui oleh pembaca, kemudian sedikit demi sedikit mengerucut pada fokus penelitian.

3. Tinjauan Pustaka

Ringkasan berupa uraian tentang penelitian penelitian terkini yang berhubungan baik secara langsung dan tidak langsung dengan penelitian. Pada bagian akhir dari tinjauan pustaka dikemukakan perbedaan penelitian yang akan dilakukan terhadap penelitian - penelitian selanjutnya.

4. Landasan teori

Landasan teori adalah uraian singkat tentang teori teori yang mendasari penelitian.

5. Hipotesis

Hipotesis adalah dugaan jawaban atas perumusan masalah yang telah diuraikan sebelumnya. Hipotesis ini akan dibuktikan selama proses penelitian. 
6. Metode Penelitian

Metode Penelitian adalah langkah - langkah sistematis yang akan dilakukan selama proses penelitian untuk memperoleh jawaban dari rumusan masalah penelitian.

7. Jadwal Penelitian

Jadwal penelitian adalah perkiraan jadwal pelaksanaan penelitian dari awal sampai akhir yang merupakan penjabaran dari metode penelitian yang telah diuraikan sebelumnya dalam bentuk kisaran tanggal. Penanda atau milestone penting juga perlu disebutkan, misalnya perkiraan waktu keluarannya suatu dokumen, perkiraan publikasi dan seminar , dan lain sebagainya.

8. Anggaran

Anggaran adalah perkiraan anggaran yang diperlukan dalam bentuk penelitian yang rinci dan lengkap.

9. Lampiran

Lampiran berisi tentang data - data awal yang dianggap dapat dipergunakan sebagai pendukung argumentasi yang dikemukakan dalam proposal penelitian. 
Penguatan materi !

1. Jelaskan pentingnya penelitian?

2. Buatlah kajian tentang makna penelitian?

3. Buatlah bagan alur tahapan penelitian dan berikan penjelasan dari tiap tahapnya?

4. Jelaskan perbedaan antara metode ilmiah dengan metodologi dalam penelitian?

5. Sebutkan dan jelaskan beberapa metodologi pengembangan sistem informasi ?

6. Buatlah desain bagan klasifikasi metode penelitian?

7. Buatlah sebuah kerangka proposal penelitian ? 


\section{BAB II TOPIK PENELITIAN, LATAR BELAKANG DAN PERUMUSAN MASALAH , HIPOTESIS}

Setelah memahami tentang makna penelitian, pentingnya penelitian, klasifikasi penelitian, metode dan metodologi , tahapan penelitian dan pembuatan proposal penelitian, maka langkah awal dalam menentukan apa yang ingin diteliti adalah menentukan topik penelitian, merumuskan masalah yang ingin di teliti , menentukan tujuan penelitian, menentukan ruang lingkup atau batasan - batasan masalah penelitian, dan menentukan hipotesis atau dugaan jawaban sementara yang ada kemungkinan jawaban tersebut menjadi solusi dari permasalahan penelitian.

\subsection{Topik Penelitian}

Topik penelitian adalah bidang atau area besar yang menjadi bidang ilmu penelitian tersebut akan dilakukan. (Emanuel, 2017).

Dalam bidang Teknologi Infromasi, ada banya topik yang dapat di pilih untuk dijadikan topik penelitian. Berikut bidang - bidang ilmu yang dapat di jadikan topik penelitian :

1. Rekayasa perangkat lunak / Software Engineering adalah Bidang ilmu yang mempelajari segala hal yang berhubungan dengan metode perancangan dan pengembangan perangkat lunak.

2. Jaringan Komputer adalah bidang ilmu yang pelajari tentang segala hal yang berhungan dengan 
perancangan dan pengembangan jaringan komputer.

3. Sistem Informasi / Information System adalah bidang ilmu yang mempelajari pengelolaan informasi melalui sebuah sistem komputerisasi agar dapat dipergunakan secara optimal

4. Pengujian Perangkat Lunak / Software Testing adalah Bidang ilmu yang mempelajari teknik teknik pengujian perangkat lunak secara efektif dan efisien

5. Kecerdasan Buatan / Artificial Intelligence adalah bidang ilmu yang berkaitan dengan sistem komputer yang memiliki kecerdasan manusia

6. Kecerdasan Bisnis / Business Intelegence adalah bidang ilmu yang mempelajari penerapan kecerdasan buatan yang bertujuan untuk mendapatkan keuntungan binis /profit

7. Komputasi awan dan grid / Cloud \& Grid Computing adalah bidang yang mempelajari penerapan komputasi secara terdistribusi dalam konfigurasi awan atau grid.

8. Datawarehouse \& Datamining adalah bidang ilmu yang mempelajari teknik penyimpanan data - data dalam jumlah besar secara efektif dan efisien . Dari data - data tersebut dapat diambil pengetahuan yang bermanfaat sehingga dapat meningkatkan keuntungan bisnis atau profit.

9. Sistem pendukung keputusan / Decision Support System adalah bidang ilmu yang menerapkan berbagai teknik dalam membantu dalam 
pengambilan keputusan yang tepat dalam suatu organisasi.

10. Arsitektur Enterprise / Enterprise Architecture adalah bidang yang mempelajari berbagai bentuk dan jenis arsitektur sistem komputer dalam skala besar atau korporasi

11. Sistem Enterprise / Enterprise System adalah bidang ilmu yang mempelajari sistem - sistem komputer yang dapat beroperasi dalam skala korporasi

12. Interaksi Manusia Komputer / Human Computer \& Interaction adalah bidang ilmu yang mempelajari optimalisasi dari teknik - teknik interaksi antara manusia sebagai user dengan program komputer

13. Pemrosesan Gambar / Image Processing adalah bidang ilmu yang mempelajari tentang metode metode dan teknik - teknik dalam pengolahan atau pemrosesan gambar.

14. Pengambilan Informasi / Information Retrieval adalah bidang ilmu yang mempelajari teknik pengambilan informasi dari kumpulan data secara efektif untuk tujuan tertentu

15. Audit Sistem Informasi / Information System Audit adalah bidang imu yang mempelajari teknik teknik untuk melakukan audit dari sistem informasi suatu organisasi

16. Manajemen / Knowledge Management adalah bidang ilmu yang bertujuan untuk mengelola berbagai pengetahuan yang terdapat dalam organisasi atau perusahaan. 
17. Komputasi dan Aplikasi Perangkat Bergerak IMobile Computing Application adalah bidang ilmu yang mempelajari penerapan aplikasi bergerak untuk komputasi.

18. Sistem dan Teknologi Kode Terbuka /Open Source System \& Technology adalah bidangn ilmu yang mempelajari teknologi dan fenomena open source baik dalam bentuk aplikasi, komunitas, ataupun hubungan antara keduanya.

19. Sematic Web \& Web 2.0 adalah bidang ilmu yang mempelajari penerapan teknologi sematic web dan web 2.0 untuk berbagai penerapan.

20. Dan masih banyak lagi

Setelah mengetahui banyaknya pilihan topik penelitian Teknologi Infromasi, tentunya akan membuat peneliti pemula kebingungan dalam menentukan pilihan topik yang sesuai . Berikut tahapan yang dapat dilakukan untuk menentukan topik penelitian di bidang Teknologi Informasi :

1. Pilihlah topik yang paling disukai

Dari pilihan topik yang ada peneliti harus memahami penjelasan dari pilihan topik tersebut, kemudian pilih topik yang paling disukai, topik yang paling disukai biasanya topik yang membuat penulis tertarik untuk mengetahui pengetahuan tentang topik tersebut. Dengan ketertarikan tersebut maka peneliti akan mencoba untuk mengetahui tentang topik tersebut melalui beberapa literatur. Apabila menyukai suatu topik, maka segala sesuatu akan terlihat mudah. Karena terlihat mudah 
maka peneliti dapat dengan mudaha mencari kata kunci pencarian di internet. Topik - topik terkait penelitian Teknologi Informasi dapat dengan mudah di dapat melalui internet.

Untuk mendapatkan informasi melalui internet , dapat digunakan mesin pencari seperti google, bing, ask, yahoo, dan lain - lain.

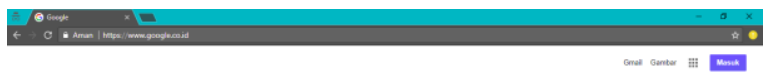

\section{Google}

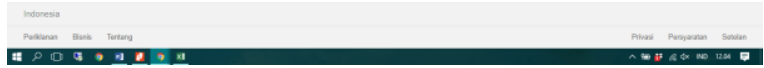

Gambar 2.1 Tampilan mesin pencari google

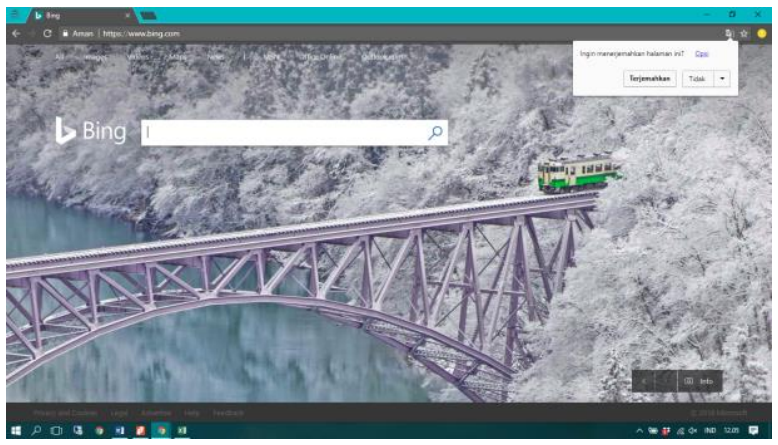

Gambar 2.2 Tampilan mesin pencari bing 


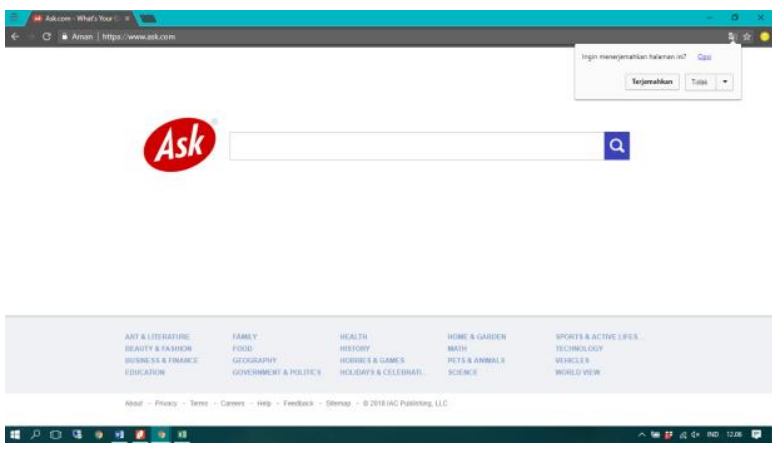

Gambar 2.3 Tampilan mesin pencari ask

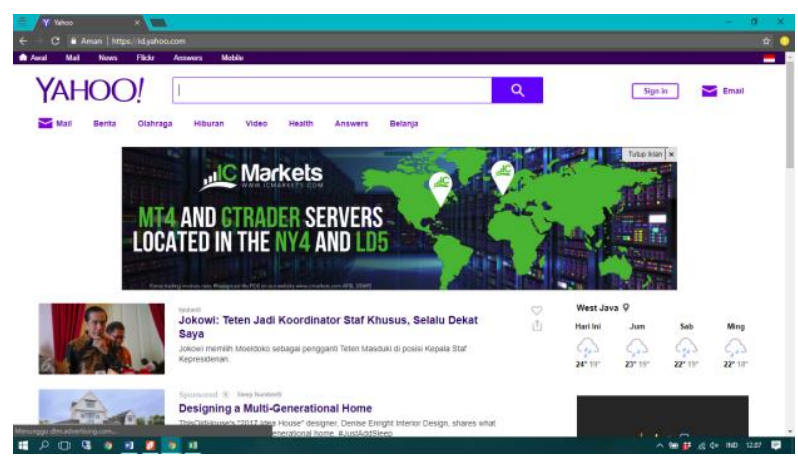

Gambar 2.4 Tampilan mesin pencari yahoo

Dari mesin pencarian tersebut dapat dimasukkan topik penelitian atau sub topik penelitian. Berikut contoh hasil pencarian tentang topik Rekayasa Perangkat Lunak dari mesin pencari google. 


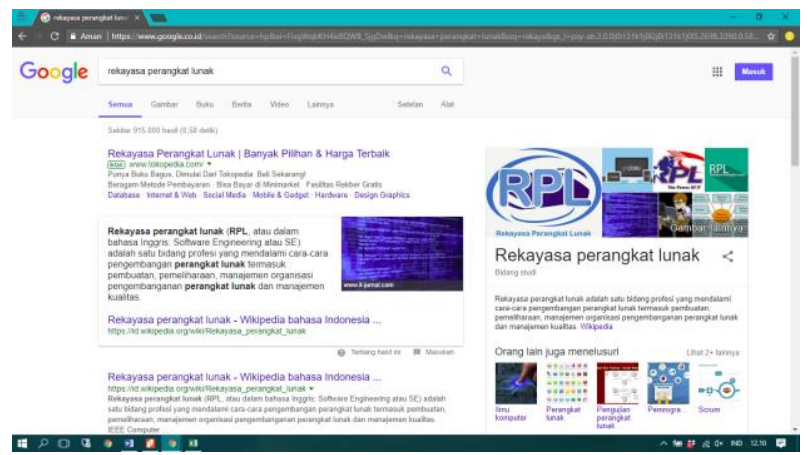

Gambar 2.5 Hasil pencarian google untuk topik Rekayasa Perangkat Lunak.

Sangat banyak informasi topik teknologi informasi yang dapat diambil dari mesin pencari.

Apabila tidak menyukai suatu topik maka yang sebenarnya mudah pun akan terlihat sulit, untuk itu penting dalam penelitian untuk mengambil topik yang disukai.

Ketika sudah mendapatkan topik yang disukai , usahakan untuk fokus pada bidang topik tersebut. Ketika sudah mendapatkan bidang yang disukai maka lebih lanjut peneliti membaca sumber yang terkait dengan topik tersebut secara lebih jauh. Karena suatu topik mungkin memeliki beberapa subtopik yang harus di pelajari lebih lanjut oleh peneliti.

\section{Buat Mindmap}

Mind maping adalah cara mengembangkan kegiatan berfikir ke segala arah, menangkap berbagai pikiran dalam berbagai sudut. Mind maping mengembangkan cara berfikir divergen dan 
berfikir kreatif. Mind mapping yang sering disebut dengan peta konsep adalah alat organisasional yang sangat hebat yang juga merupakan cara termudah untuk menempatkan informasi ke dalam otak dan mengambil informasi itu ketika dibutuhkan. (Buzan, 2008).

Menurut Tony Buzan, Mind maping dapat membantu dalam banyak hal seperti merencanakan, berkomunikasi, menjadi lebih kreatif, menyelesaikan masalaha, memusatkan perhatian , menyusun dan menjelaskan pikiran - pikiran , mengingat dengan baik, belajar lebih cepat dan efisien serta melatih gambar keseluruhan,

3. Fokus ke subtopik tertentu

Ketika sudah mendapatkan beberapa kandidat topik yang menarik maka langkah selanjutnya adalah mencari fokus dari penelitian dengan melihat subtopik yang ada. Dari subtopik tersebut kemudian di pelajari secara mendalam kemudian temukan spesialisasi bidang penelitian yang dapat dijadikan sebagai fokus penelitian yang akan dilakukan. Beberapa strategi yang dapat diterapkan agar fokus pada bidang penelitian yang ditekuni :

a. Abaikan topik yang terlihat sukar, karena ada kemungkian tidak mungkin di teliti

b. Lihat topik yang terlihat mudah sehingga akan mudah di teliti lebih lanjut

c. Sebuah penelitian dapat diteliti apabila parameter - parameter yang ditemukan dalam topik atau subtopik tersebut dapat terukur 
d. Hampir semua bidang ilmu dapat diteliti dan untuk parameter - parameter yang bersifat kualitatif tetap dapat diukur tingkat persepsinya terhadap sekelompok orang.

\subsection{Latar Belakang dan Perumusan Masalah}

1. Menyusun Latar Belakang

Pada proposal atau laporan hasil penelitian terdapat bab pendahuluan, pada umumnya bab pendahuluan ini mencantumkan tiga hal yaitu latar belakang, rumusan masalah dan tujuan penelitian. Dalam menyusun latar belakang penelitian, yang paling penting adalah menjelaskan argumentasi atau alasan mengapa memilih topik penelitian itu. Sebuah argumentasi disusun dengan mengungkapkan (a) konteks permasalahan yang terkait dnegan bidang keilmuan peneliti, (b) bukti atau data , konsep - konsep dan hubungan antar variabel yang terkait dengan topik yang akan diteliti dengan merujuk pada fakta - fakta yang diperoleh dari hak yang memiliki otoritas dari observasi selintas dan dari bukti ilmiah berdasarkan literatur atau laporan penelitian terkait.

Cara yang mudah untuk menyajikan latar belakang ini adalah dengan mengkontradiksikan , membandingkan antara kebijakan, teori atau konsep - konsep dari satu pihak, dengan fenomena masalah yang ada dari pihak lain. Latar belakang masalah penelitian menjelaskan topik penelitian secara konprehensif , masalah penelitian yang dipilih dan mengapa penelitian perlu dilakukan. 
Latar belakang masalah adalah informasi yang tersusun secara sistematis yang terkait dengan fenomena dan problematika yang menarik untuk diteliti. Permasalah terjadi karena adanya gap anatara harapan ideal dengan kenyataan yang ada. Sedangkan fenomenal adalah seuatu yang menarik perhatian dan dibicarakan di berbagai kalangan masyarakat. Dalam menyusun latar belakang penting melihat permasalahan dan pendekatan apa yang digunakan untuk menyelesaikan masalah tersebut .

Latar belakang penelitian berisi tetang alasan rasional dan esensial yang membuat peneliti tertarik untuk melakuakn penelitian berdasarkan fakta, data, referensi dan penemuan penelitian sebelumnya. Gejala kesenjangan yang terjadi di lapangan sebagai dasar pemikiran untuk memunculkan permasalahan dan bagaimana penelitian mengisi ketimpangan yang ada kaitannya dengan topik yang diteliti. Kompleksitas masalah jika masalah tersbeut dibiarkan maka akan berdampak menyulitkan, menghambat, mengganggu bahkan mengancam . Penjelasan singkat tentang kedudukan atau posisi masalah yang diteliti dalam ruang lingkup bidang yang diteliti perlu ditekuni oleh peneliti.

(Wirartha, 2006) Setiap penelitian yang diajukan harus menyampaika latar belakang masalah yang nyata nyata memerlukan pemecahan masalah. Latar belakang yang jelas akan memudahkan perumusan masalah, dimana pada tahap ini secara garis besar diuraikan masalah yang akan diteliti, mengapa penelitian, bagaimana cara menelitinya dan untuk apa masalah itu di teliti. 
(Echdar, 2017)Berikut hal - hal yang perlu diperhatikan dalam menyusun latar belakang masalah :

a. Memahami masalah

Sebelum melakukan penelitian, seorang peneliti harus menentukan masalah yang ingin diteliti. Permasalahan dalam penelitian merupakan titik awal yang berfungsi sebagai pemersatu ide awal dengan fenomena - fenomena yang terjadi . Pernyataan permasalahan harus mengandung konteks dapat mengungkapkan seberapa penting penelitian yang akan dilakukan dapat berkontribusi terhadap kemajuan bidang ilmu yang akan dikaji.

Menurut (Ruseffendi, 2005) masalah dikapatan baik apabila memiliki ciri - ciri sebagai berikut :

1) Masalah dapat diteliti

2) Adanya kontribusi terhadap pengetahuan sesuai dengan bidang yang diteliti

3) Pemecahan baik bagi peneliti.

Menurut (Purwanto, 2007) menurut jenisnya masalah dapat dibedakan menjadi tiga yaitu :

1) Masalah deskriptif yaitu masalah yang mendeskripsikan suatu variabel pada satu kelompok tanpa menghubungkan dengan variabel yang lain atau membandingkan dengan kelompok lain.

2) Masalah korelasi yaitu masalah yang memuat hubungan antara satu atau lebih variabel dengan satu atau lebih variabel yang lainnya. 
3) Masalah perbandingan yaitu masalah yang memuat perbandingan satu atau lebih kelompok ke dalam satu variabel.

b. Studi Literatur

Studi literatur adalah suatu cara untuk menyelesaikan permasalahan dengan menelusuri sumber - sumber tulisan yang pernah dibuat sebelumnya . Sumber tulisan harus terpercaya, biasanya diambil dari pengarang - pengarang terpercaya, jurnal - jurnal ilmiah yang terakreditasi dan hasil - hasil penelitian. Menurut (Echdar, 2017)ada beberapa metode yang dapat digunakan untuk melakukan studi literatus seperti mengupas (critize), membandingkan (compare), meringkas (summarize) dan mengumpulkan (synthesis) suatu literatur.

c. Cara menyusun latar belakang

Setelah peneliti mendapatkan masalah langkah selanjutnya adalah menuliskan secara terstruktur pada bab pendahuluan . Latar belakang disusun secara terstruktur sehingga benang merah permasalahan dapat dipahami dengan baik oleh para pembaca.

Menurut (Echdar, 2017) secara teknis, langkah langkah dalam menyusun latar belakang adalah :

1) Kemukakan arti penting atau peranan penting atau manfaat dari variabel terikat bagi organisasi maupun bagi karyawan, atau pihak lain. Dukungan dengan referensi dari buku atau jurnal. 
2) Kemukaan gejala - gelajal masalah yang berkaitan dengan variabel tersebut, didukung dengan dokumen, hasil pengamatan, wawancara atau angket yang telah diperoleh dari hasil penelitian terdahulu.

3) Kemukakan faktor -faktor apa saja yang bisa mempengaruhi variabel tersebut, didukung dengan referensi dari buku teks atau jurnal

4) Pilih satu atau beberapa faktor tersebut yang dianggap paling penting dijadikan variabel terikat dalam penelitian kita

5) Kemukakan gejala - gejala masalah dari setiap faktor yang sudah dipilih tersebut, dukung dengan dokumen, hasil pengamatan , wawancara atau angket yang diperoleh dari hasil penelitian pendahukuan (prariset).

\section{Perumusan Masalah}

Setelah melihat sisi waktu, biaya, kemampuan peneliti maupun kontribusi yang akan diberikan oleh peneliti tersebut terhadap pengembangan ilmu pengetahuan dan tekologi, akhirnya peneliti memilih masalah penelitian.

Tanpa ada permasalahan yang jelas, sebuah penelitian tidak dapat dilakukan karena perumusan masalah merupakan sumber utama dari penelitian yang akan dilakukan.

Rumusan masalah merupakan pernyataan dari penyimpangan, pernyataan dari kontroversi yang ada dalam penelitian maupun pernyataan mengenai gagalnya atau kurang mampunya sebuah teori menjelaskan sesuatu. (Echdar, 2017) 
Beberapa ahli mendefinisikan tentang rumusan masalah, diantaranya sebagai berikut :

(Pariatra, 1981)Suatu masalah yang terjadi apabila seseorang berusaha mencoba suatu tujuan atau percobaannya yang pertama untuk mencapai tujuan itu hingga berhasil.

(Hadi, 2004)Masalah adalah kejadian yang menimbulkan pertanyaan apa dan kenapa.

(Sugiono, Memahami Penelitian Kualitatif, 2016) Masalah merupakan penyimpangan dari apa yang seharusnya dengan apa yang terjadi , penyimpangan antara teori dengan praktik , penyimpangan antara aturan dengan pelaksanaan , dan penyimpangan antara rencana dengan pelaksanaan , dan penyimpangan antara pengalaman masa lampau dengan yang terjadi sekarang.

(Echdar, 2017)Supaya masalah yang akan dipilih benar - benar tepat, biasanya masalah perlu dievaluasi berdasarkan beberapa parameter yaitu, sebagai berikut :

a. Menarik, masalah yang menarik membuat kita termotivasi untuk melakukan penelitian dengan serius

b. Bermanfaat, penelitian harus membawa manfaat baik untuk ilmu pengetahuan maupun peningkatan kesejahteraan dan kualitas kehidupan manusia.

c. Hal yang baru.

d. Dapat diuji (di ukur), supaya proses penelitian sempurna, masalah penelitian 
beserta variabel - variabelnya harus merupakan sesuatu yang bisa diuji dan diukur secara empiris.

e. Dapat dilaksanakan, ini berkaitan dengan keahlian, ketersediaan data, kecukupan waktu dan dana

f. Merupakan masalah yang penting.

g. Tidak melanggar etika

Berikut dapat dilihat contoh alternatf masalah penelitian

RUMUSAN MASALAH

Kesulitannya Bagian

akademik dalam

mendokumentasikan

absensi mahasiswa
RUMUSAN MASALAH PENELITIAN

Bagaimana membuat sistem informasi absensi menggunakan framework CodeIgniter untuk memberikan kemudahan bagian akademik dalam mendokumentasikan absensi mahasiswa

Gambar 2.6 Alternatif masalah penelitian

(Echdar, 2017)Berdasarkan kajian referensi buku buku metode penelitian, setidaknya terdapat tujuh syarat yang harus dipenuhi dalam perumusan masalah penelitian :

a. Tersedia data atau informasi untuk menjawabnya

b. Data atau informasi tersebut diperoleh melalui metode ilmiah, seperti wawancara, observasi, kuesioner, dokumentasi, partispasi, dan evaluasi. 
c. Memenuhi persyaratan orisinilitas , diketahui melalui pemetaan penelitian terdahulu

d. Memberikan sumbangan teoretik yang berarti bagi pengembangan pengetahuan

e. Menyangkut isu kontroversial dan unik yang sedang hangat terjadi

f. Masalah tersebut memerlukan jawaban serta pemecahan segera, tetapi jawabannya belum diketahui masyarakat luas.

g. Masalah itu diajukan dalam batas minat (bidang studi), dan kemampuan peneliti.

\subsection{Tujuan Penelitian}

Setelah perumusan masalah langkah selanjutnya adalah menentukan tujuan dari penelitian. (Emanuel, 2017)Tujuan penelitian merupakan pernyataan yang berisi apa yang ingin dicapai pada penelitian yang kemudian akan dijawab apakah tujuan tersebut telah dipenuhi dalam kesimpulan dari penelitian . Berikut contoh tujuan penelitian :

RUMUSAN MASALAH PENELITIAN

Bagaimana membuat sistem informasi menggunakan framework CodeIgniter untuk memberikan kemudahan bagian akademik dalam mendokumentasikan absensi mahasiswa

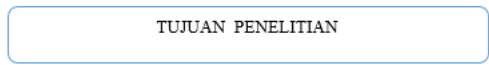

Merancancang sistem informasi absensi menggunakan framework CodeIgniter untuk memberikan kemudahan bagian akademik dalam mendokumentasikan absensi masiswa

Gambar 2.7 Contoh tujuan penelitian 


\subsection{Ruang Lingkup Penelitian atau Batasan Masalah Penelitian}

Sebuah penelitian tidak dapat memberikan solusi dari permasalahan yang luas lingkupnya, namun akan cenderung mencoba mencari solusi dari permasalahan dalam lingkup yang spesifik . untuk menghindari cakupan masalah yang terlalu luas maka perlu adanya batasan masalah atau ruang lingkup permasalahan.

(Emanuel, 2017)tujuan dari batasan masalah adalah :

1. Menjelaskan batas - batas dari solusi permasalahan yang ingin di capai.

2. Menyatakan bidang - bidang mana saja yang bersinggungan erat dengan bidang penelitian namun tidak akan dianalisis secara mendalam dalam penelitian.

Berikut contoh batasan masalah berdasarkan contoh perumusan masalah dan tujuan penelitian diatas :

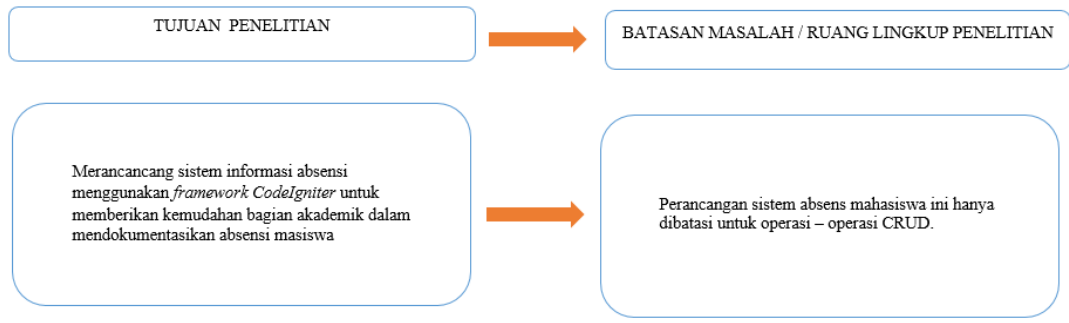

Gambar 2.8 Contoh Batas masalah atau Ruang Lingkup penelitian 


\subsection{Merumuskan Hipotesis}

Setelah peneliti menentukan permasalahan, tujuan penelitian, ruang lingkup penelitian atau batasan masalah, langkah selanjutnya adalah menentukan hipotesis. (Emanuel, 2017)Hipotesis adalah dugaan atau perkiraan jawaban dari permasalahan yang ditemukan yang akan dibuktikan kebenarannya selama proses penelitian. Jumlah hipotesis bisa satu ataupun banyak tergantung dari kemampuan intusis penelitinya. Proses dari penelitian selanjutnya adalah berusaha membuktikan hipotesis hipotesis yang dikemukakan berdasarkan hasil analisis dan penafsiran data yang telah dikumpulkan.

(Mercubuana, 2015)Hipotesis yang dirumuskan biasanya diambil berdasarkan kumpulan teori yang sesuia dengan topik penelitian serta hasil dari penelitian penelitian terdahulu. Hipotesis tersebut bisa berupa hipotetical statement, misalnya IT invesment meningkatkan kinerja perusahaan. Selain itu juga ada statisikal hipotesis , misalnya $(\mathrm{H} 0)$ : rata - rata pengunjung sebelum dan sesudahnya sama atau rata - rata jumlah customer sebelum dan sesudah sama. Merumuskan hipotesis harus kuat dasarnya seperti riset problem, scope of the riset, dan tujuannya. Bila rumusan hipotesis sudah kuat seperti apa yang akan diuraikan dalam laporan terutama pada bab hasil dan interprestasi dan bab lima kesimpulan, maka kesimpulan yang akan diambil didasarkan pada hipoteisis dan data - data dari hasil penelitian. Semuanya berdasarkan sekuat apa peneliti dalam menetapkan problem. Hipotesis mempunyai peranan memberikan arah dan tujuan 
pelaksanaan penelitian, dan memandu ke arah penyelesainanya secara lebih efisien. Hipotesis yang baik akan menghindarkan penelitian tanpa tujuan, dan pengumpulan data yang tidak relevan. Perlu diingat, bahwa tidak semua penelitian memerlukan hipotesis. Misalnya penelitian yang bersifat deskriptif, penelitian eksploratif dan penelitian yang bersifat kualititatif. Manfaat penggunaan hipotesis antara lain yaitu :

1. Untuk menjelaskan permasalahan yang diangkat dalam penelitian

2. Untuk menjelaskan variabel - variabel yang akan diuji kebenarannya

3. Untuk membantu dalam memilih metode analisis data

4. Sebagai pedoman dalam menarik sebuah kesimpulan. 


\section{Penguatan materi !}

1. Pilihlah sebuah topik penilitian .

2. Susunlah latarbelakang dari topik yang di pilih .

3. Susunlah rumusan masalah penelitian dari topik yang anda pilih.

4. Tentukan tujuan penelitian dari topik yang anda pilih

5. Tentukan batasan masalah atau ruang lingkup penelitian dari topik yang anda pilih .

6. Tentukan hipotesis atau dugaan jawaban dari permasalah penelitian yang telah anda tentukan. 


\section{BAB III KAIIAN PUSTAKA}

Kajian pustaka merupakan bagian penting dalam sebuah penelitian. Kajian pustaka memiliki tujuan untuk menginformasikan kepada pembaca, hasil - hasil penelitian yang berkaitan erat dengan penelitian yang dilakukan, terkait dengan sumber - sumber literatur yang ada.

\subsection{Pengertian Kajian Pustaka}

Yang termasuk kedalam kajian pustaka adalah daftar referensi dari semua jenis referensi seperti buku, jurnal publikasi, artikel, disertasi, tesis, skripsi, handout dan karya ilmiah lainnya yang dikutip dalam penulisan . Semua referensi yang ditulis dalam kajian pustaka harus ditulis rujukannya.

Kajian pustaka berisi tentang teori - teori yang relevan dengan masalah yang diangkat pada penelitian . pada kajian pustaka dilakukan pengkajian mengenai konsep - konsep teori yang digunakan sebagai pisau bedah untuk mencari solusi dari permasalahan penelitian.

(Sugiono, Metode Penelitian Kuantitatif, Memahami Penelitian Kualitatif)Noumen memaparkan bahwa kajian pustaaka adalah seperangkat konstruksi atau konsep, definisi dan proposisi yang berfungsi untuk melihat fenomena secara sistematik, melalui spesifikasi hubungan antara variabel sehingga dapat digunakan untuk menjelaskan dan meramalkan fenomena. 
(Echdar, 2017)Kajian pustaka adalah kegiatan yang meliputi mencari, membaca dan menelaah laporan laporan penelitian dan bahan pustaka yang memuat teori - teori yang relevan dengan penelitian yang akan dilakukan. Kriteria pemilihan sumber pustaka mencakup hal berikut :

1. Ketetapan (adequacy). Isi dari sumber pustaka sesuai dengan penelitian yang dilaksanakan.

2. Kejelasan (clarity). Sumber pustaka harus mudah dipahami atau dimengerti oleh peneliti.

3. Empiris (empericalness). Sumber pustaka itu berdasarkan pada kenyataan bukan hasil imajinasi.

4. Terorganisasi (organization). Isis dari sumber pustaka harus terorganisasi dengan baik sehingga memudahkan peneliti untuk mencari informasi.

5. Kemutakhiran (recency). Sumber pustaka harus berdasarkan perkembangan terbaru dalam bidangnya (up to date)

6. Relevansi (relevance). Sumber pustaka berhubungan dengan penelitian

7. Meyakinkan (convicingness)

(Echdar, 2017)Geoffrey dan Airasian (2009) mengemukakan bahwa tujuan kajian pustaka adalah untuk menentukan apa yang telah dilakukan orang yang berhubungan dnegan topik penelitian yang akan dilakukan.

Jadi dapat disimpulkan bahwa kajian pustaka adalah aktivitas dalam penelitian yang bertujuan untuk mengkaji teori - teori dan konsep - konsep yang berkaitan dengan 
topik yang diteliti sebagai acuan untuk melangkah ke tahapan penelitian berikutnya.

(Echdar, 2017)Berdasarkan penggunaan acuan, yaitu sumber acuan umum dan khusus, maka secara garis besar sumber bacaan dibedakan menjadi tiga macam sebagai berikut :

1. Referensi umum adalah seumber yang dijadikan rujuakan utama oleh peneliti, misalnya dari artikel tertentu, karangan ilmiah,buku, dan dokumen lainnya yang berkaitan langsung dengan pertanyaan penelitian. Referensi umum merupakan indeks, yaitu daftar daftar pengarang, judul buku, tempat penerbutan artikel atau wacana atau berupa abstrak.

2. Sumber primer adalah publikasi dimana seseorang melakukan penelitian kemudian diterbitkan. Penulis mengkomunikasikan temuannya secara langsung kepada pembaca. Sumber primer penelitian manajemen adalah jurnal - jurnal interkom. Ada jurnal yang diterbitkan dua kali dalam setahun, tiga kali dalam setahun, dan artikel yang dimuat merupakan laporan hasil penelitian.

3. Sumber sekunder adalah publikasi di mana penulis mendeskripsikan hasil karya orang lain. Sumber sekunder adalah buku(tekt books), ensiklopedia , kajian penelitian atau buku laporan tahunan perusahaan.. 


\subsection{Fungsi dan Tujuan Kajian Pustaka}

Kajian pustaka sangat berguna untuk peneliti dalam menyelesaikan masalah yang diangkat menjadi topik penelitian serta menjelaskan kedudukan masalah dalam tempat yang lebih luas. Kajian teoritik yang ada dalam kajian pustaka akan menjadi landasan peneliti dalam menyelesaikan penelitiannya. (Echdar, 2017)Menurut Zubaidah fungsi kajian pustaka adalah untuk :

1. Mengetahui sajarah masalah peneitian

2. Membantu memilih prosedur

3. Memahami latar belakang teoritis masalah penelitian

4. Mengetahui manfaat penelitian sebelumya.

5. Menghundari duplikasi

6. Memberikan pembenaran pemilihan masalah penelitian.

(Echdar, 2017)Sebuah kajian pustaka memberikan informasi kepada pembaca tentang peneliti dan kelompok yang memiliki pengaruh dalam suatu bidang tertentu. Penulisan kajian pustaka dalam sebuah penelitian memiliki tujuan sebagai berikut :

1. Memberikan kepada pembaca kemudahan memperoleh sebuah topik tertentu dengan cara menyeleksi artikel - artekel atau bahan kajian yang berkualitas yang relevan bermakna penting, sahih dan merangkainya dalam suatu laporan yang lengkap.

2. Memberikan awalan yang sangat bagus bagi peneliti untuk mengawali penelitian dalam suatu biadang tertentu dengan cara menuntut peneliti 
untuk merangkum, menilai dan membandingkan penelitian dalam bidang tertentu.

3. Memastikan bahwa peneliti tidak melakukan duplikasi hasil kerja yang telah dilakukan.

4. Memberikan petunjuk ke mana penelitian yang akan datang diarahkan atau direkomendasikan.

5. Memberikan garis besar temuan kunci

6. Mengidentifikasi ketidaksesuaian, kesenjangan dan hal yang mengandung perentangan dalam kajian pustaka.

7. Memberikan analisis konstrktif tentang metodologi dan pendekatan dari para peneliti lain.

Pada setiap penelitian pasti mempunyai tujuan dan kegunaan tertentu, namun secara umum tujuan penelitian dapat terbagi menjadi tiga macam yaitu bersifat penemuan, pembuktian dan pengembanga. Penemuan berarti data hasil penelitian belum ditemukan sebelumnya - Pembuktian berarti data yang diperoleh dari hasil penelitian merupakan pembuktian kebenaran teori tertentu. Sedangkan pengembangan berarti data yang diperoleh dari hasil penelitian adalah pendalaman atau perluasan dari penelitian yang telah ada.

Dalam menyusun kajian pustakan penelitian diperlukan kiat - kiat khusus agar tersajikan dengan baik. Berikut dikemukakan cara merangkai kepustakaan yang baik (Echdar, 2017) :

1. Mulailah dengan minat dibidang penelitian, cari yang paling akhir dimuat dalam terbitan terbaru dan kemudian mundur ke keterbitan sebelumnya.

2. Bacalah abstrak atau ringkasan suatu laporan terlebih dahulu untuk menetapkan apakah laporan 
itu relevan dengan masalah yang sedang diteliti atau tidak.

3. Buatlah catatan langsung pada kartu catatan karena itu lebih mudah diseleksi dan disusun dari pada lembaran kertas atau amplop.

4. Sebelum membuat catatan, baca laporan penelitian dengan tepat mengetahui bagian - bagian mana yang ada kaitannya dnegan masalah yang diteliti.

5. Tulislah referensi bibliografi(nama pengarang, tahun, judul buku, nama jurnal, volume buku, nomor, penerbit, tempat terbit dan halaman) secara lengkap setiap karyanya.

6. Untuk memudahkan pemilihan dan penyusunan jangan memasukkan lebih dari satu referensi pada satu kartu.

7. Jangan lupa beri tanda bagian mana yang merupakan kutipan langsung dari pengarang dan bagian mana yang merupakan susunan kata - kata sendiri.

Kajian pustaka dalam penelitian sangat berperan penting. Kajian pustaka memiliki kontribusi pada penelitian sebagai teori dasar masudnya penelitian tidak berarti tanpa teori. Kajian pustaka memiliki kontribusi debagai tolok ukur maksudnya kerangka teori berfungsi sebagai patokan. Kajian pustaka juga berkontribusi sebagai sumber hipotesis, kerangka teori sebagai rasionalisasi mengapa harus diuji kembali, karena pembuktian secara teoritis harus diimbangi dengan pembuktian secara empirik. 


\subsection{Mencari Referensi di Internet}

Kemajuan teknologi memberikan kemudahan kepada peneliti untuk mencari sumber referensi dan hasil - hasil karya ilmiah . kemajuan teknologi tersebut adalah teknologi internet. Jika sebelumnya seorang peneiti harus membeli buku atau mendatangi perpustakaan untuk mendapatkan referensi namun sekarang cukup terkoneksi dengan internet dan kemudian mengetik pada mesin pencarian di interent tentang informasi apa yang ingin dicari. Sekarang buku, publikasi jurnal ilmiah , prosiding dan karya ilmiah lainnya sudah tersedia secara digital.

Telah dibahas sebelumnya beberapa mesin pencari di internet yaitu yahoo, google, bing dan lain - lain. Namun semakin banyaknya informasi, peneliti harus dapat memilih mana informasi yang terpercaya . berikut beberapa situs yang dapat membantu peneliti mendapatkan informasi yang relevan adalah sebagai berikut :

\section{Google scholar atau google cendikia}

Google scholar atau google cendikia adalah mesin oencari yang dibuat khusus oleh goole untuk pencarian hasil karya ilmiah, kutipan dan paten. Google Scholar atau google cendikia ini sangat berbeda dengan mesin pencari lainnya karena hasil pencariannya langsung menuju pada karya - karya ilmiah dan hasil dapat di batasi berdasarkan tahun dan bentuk karya ilmiahnya. Berikut contoh tampilan google scholar atau google cendikia : 


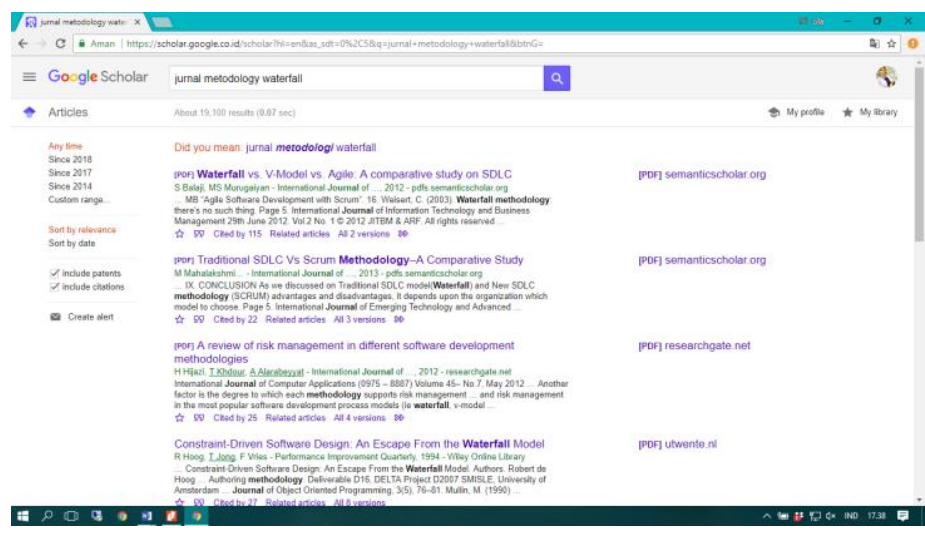

Gambar 3.1 Hasil pencarian menggunakan google scholar atau google cendikia

Terlihat di sebelah kanan adalah sumber tauatan. Dan yang muncul pada hasil pencarian adalah berupa karya - karya ilmiah dalam betuk $p d f$. Dengan adanya google scholar ini akan memberikan kemudahan kepada peneliti dalam mendapatkan sumber yang terpercaya.

\section{DOAJ (Directory of Open Access Journals)}

DOAJ adalah web portal yang berisi tentang publikasi - publikasi ilmiah yang bersifat terbuka atau open acsess. Bersifat terbuka atau open acsess maksudnya adalah siapa saja boleh menggunakan atau mengakses portal ini tanpa dipungut biaya. Langkah untuk masuk ke web portal DOAJ adalah dengan dengan mengakses http://www.doaj.org maka akan tampil halaman seperti berikut : 


\section{lentions}

Directory of Open Access Journals (DOAJ)

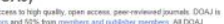

Latest News

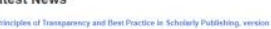

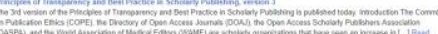

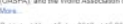

Gambar 3.2 Tampilan portal DOAJ

Gambar 3.2 meruapakan tampilan dari portal DOAJ. Untuk mencari artikel atau karya ilmiah cukup menuliskan kata pencarian di text box pencarian . Berikut adalah tampilan hasil pencarian dari kata kunci waterfall.

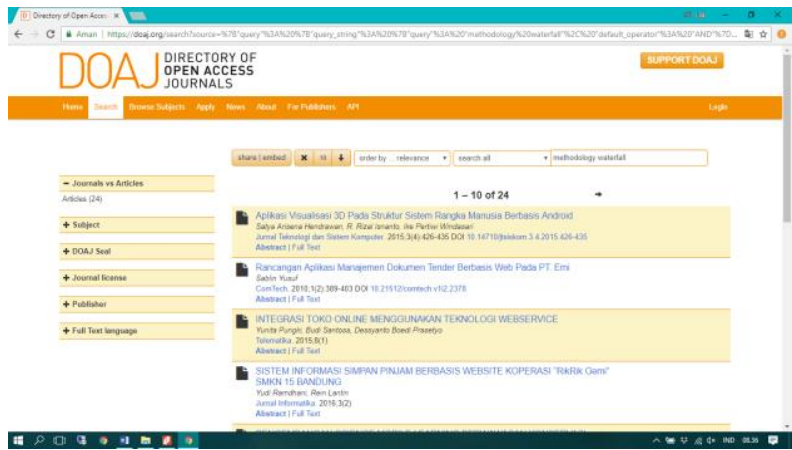

Gambar 3.3 Tampilan hasil pencarian dengan kata kunci "waterfall"

Disamping sebagai tempat pencarian publikasi karya ilmiah , DOAJ juga berfungsi sebagai penerbitan jurnal karya ilmiah yang bersifat open acsess. 


\section{Porta Garuda (Indonesia Publication Index)}

Portal garuda adalah web portal yang berfungsi untuk publikasi karya ilmiah yang dikembangkan oleh Institute of Advance Engineering and Science (IAES). IAES meruapakan basis data publikasi publikasi karya ilmiah di Indonesia. Berikut tampilan dari Portal Garuda .

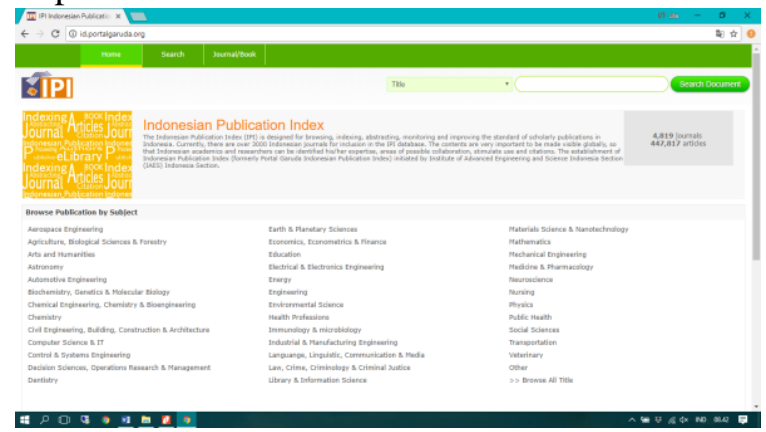

Gambar 3.4 Tampilan Portal Garuda

Dapat kita lihat pada gambar 3.4 tampilan Portal Garuda terdapat subject atau kategori dari publikasi ilmilah yang ada di basis data Portal garuda.

\section{Portal Publikasi Ilmiah berbayar}

Tidak semua karya - karya ilmiah hasil penelitian di publikasikan secara gratis, ada beberapa hasil karya ilmiah yang berkualitas didapat dengan cara membayar. Ketika membuka situs atau portalnya gratis akan tetapi ketika akan mengunduh dikenakan biaya . Namun biasanya perguruan tinggi tertentu dan perpustakaan - perpustakaan berlangganan publikasi ilmiah berbayar ini . Jadi jika ingin mendapatkan sumber silahkan hubungu 
perguruan tinggi di instansi anda atau perpustakaan - beberapa contoh situs portal publikasi ilmiah berbayar adalah : IEEEXplore, Elsevier , ScienceDirect, Emerald, dan lain - lain.

Berikut adalah tampilan dari portal publikasi ilmiah berbayar.

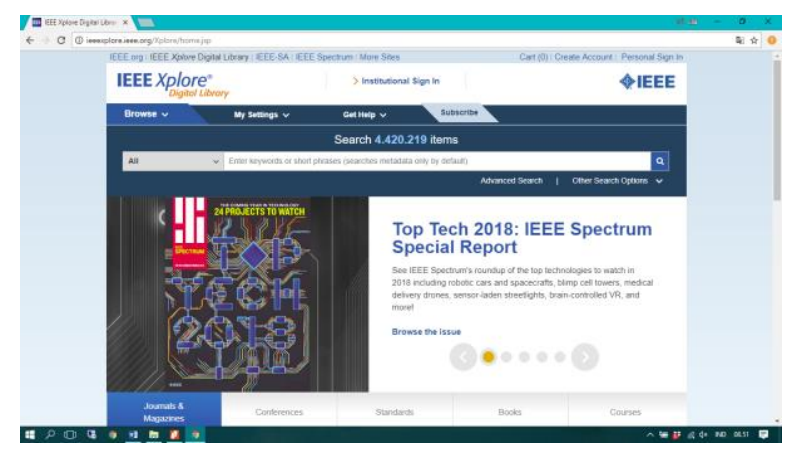

Gambar 3.5 Tampilan portal IEEE Xplore

Gambar 3.5 menunjukan tampilan portal IEEE Xplore ada beberapa jenis publikasi jurnal, majalah dengan beberapa kategori bidang penelitian.

Portal selanjutnya adalah portal publikasi ilmiah elsevier . 


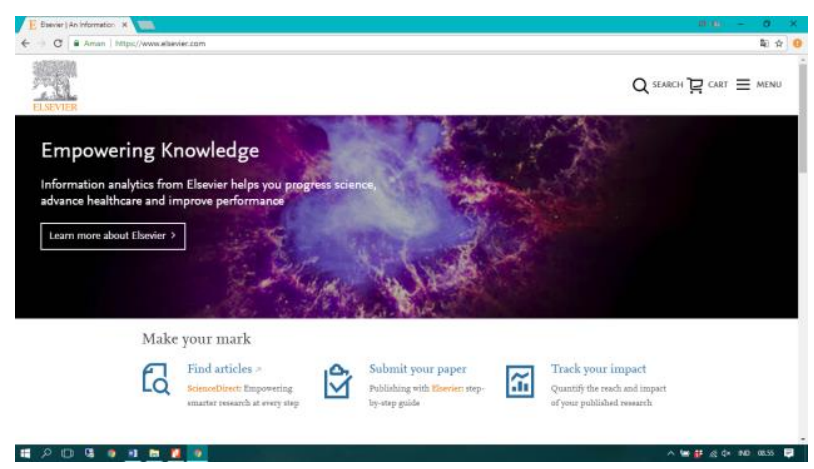

Gambar 3.6 Tampilan portal publikasi ilmiah Elsevier

Dalam portal ini ada beberapa publikas yang diberikan secara gratis dan beberapa berbayar. Banyak perguruan tinggi yang berlangganan dengan portal publikasi ilmiah ini. Elsevier mendapatkan keuntungan dari biaya langganan yang dibayarkan oleh perpustakaan, perguruan tinggi atau lembaga pendidikan lainnya.

\subsection{Meringkas Referensi Penting}

Dalam mengunduh hasil publikasi ilmiah, tidak semua publikasi yang di unduh berguna, kadang hasil publikasi ilmiah tersebut tidak relevan dengan penelitian yang akan dilakukan dan kadang memiliki kualitas yang kurang. Untuk itu diperlukan sebuah strategi agar peneliti dapat menemukan dengan mudah karya atau publikasi ilmiah yang sesuai dengan penelitian yang akan dilakukan.

(Emanuel, 2017)Berikut strategi - strategi yang perlu diterapkan dalam melakukan seleksi publikasi ilmiah antara lain : 
1. Mencari judul - judul publikasi ilmiah yang terlihat menarik. Judul merupakan indikator awal dalm menyeleksi suatu publikasi ilmiah apakah bisa menjadi kandidat referensi penelitian yang sedang dilakukan atau tidak. Sebuah judul sudah memuat topik spesifik, metode atau pendekatan yang dilakukan dan studi kasus yang ditelaah.

2. Membaca intisari atau abstrak karya ilmiah. Salah satu bagian penting lainnya yang perlu dibaca dengan seksama adalah intisari atau abstrak dari publikasi ilmiah tersebut. Intisari atau abstrak merupakan ringkasan yang sangat padat yang menjelaskan tentang permasalahan penelitian, metode penelitian yang ditempuh, dan hasil - hasil yang telah didapatkan.

3. Membaca bagian akhir dari pengantar. Suatu publikasi ilmiah pasti terdapat pengantar yang berfungsi memberikan latar belakang permasalahan yang ingin diselesaikan dalam penelitiannya. Pada bagian akhir dari pengantar biasanya dikemukakan rumusan permasalahan secara eksplisit dari penelitian tersebut yang menyatakan fokus dari penelitian yang dilakukan.

4. Membaca bagan terakhir dari tinjauan pustaka yang berisi keaslian penelitian. Pada bagian akhir dari tinjauan pusataka biasanya terdapat pernyataan orisinalita penelitian yang dilakukan. Pada bagian ini dapat diketahui perbedaan utama dari penelitian yang dipublikasikan tersbeut apabila dibandingkan dengan penelitian - penelitianlainnya.

5. Membaca bagian kesimpulan atau bagian akhir dari publikasi ilmiah. Bagian kesimpulan dari suatu publikasi ilmiah merupakan ringkasan temuan dari 
penelitian dan sekaligus juga jawaban dari rumusan permasalahan.

6. Membaca kalimat pertama dari setiap paragraf. Seelah menemukan sebuah artikel ilmiah yang menarik, langkah selanjutnya yang dapat dilakukan untuk lebih memahami artikel tersebut adalah dengan membaca kalimat pertama dari setiap paragraf. Sebuah tulisan yang disusun dengan baik selalu diawali dengan kalimat utama di setiap awal paragraf. Membaca setiap kalimat pertama di semua paragraf akan memberikan pemahaman yang lebih dari karya ilmiah tersbeut.

7. Membaca dengan seksama karya ilmiah yang dipilih. Sebuah karya ilmiah yang terpilih perlu dibaca dengan seksama secara utuh dari awal hingga akhir untuk dapat memahami karya ilmiah tersbeut dengan baik dan benar.

Setelah mengetahui strategi - strategi memilih karya ilmiah untuk mendokumentasikannya dalam bentuk ringkasan diperlukan langkah - langkah sebagai berikut :

1. Judul publikasi ilmiah

2. Pengarang

3. Jenis publikasi ilmiahnya lengkap dengan penerbit dan waktu penerbitan karya ilmiah tersebut

4. Halaman dari paper karya ilmiah tersebut

5. Ringkasan singkat yang dituliskan dengan kata kata sendiri bukan mengcopy kata - kata dari paper tersebut, untuk menghindari plagiat.

Dengan meringkas karya - karya ilmiah yang telah didapat dan disusun berdasarkan index yang diinginkan penulis memiliki beberapa manfaat diantaranya : dapat 
dijadikan referensi untuk penelitian selanjutnta, tinjuan pustaka akan menjadi lebih baik dan akurat, bisa dijadikan kutipan, sebagai salah satu pendukung untuk pencarian inspirasi penelitian yang baru, dan memudahkan dalam membaca cepat sebuah publikasi karya ilmiah.

Ringkasan karya - karya ilmiah ini perlu di tambah dan di perbaharui agar penelitian yang akan dilakukan dapat up to date.

\subsection{Membuat Peta Pikiran dari Referensi - Referensi} Penting

Peta pikiran yang lengkap merupakan hasil kumpulan referensi - referensi penting yang ditampilkan secara visual. Peta pikiran ini digunakan sebagai sarana untuk memahami secara keseluruhan dari penelitian yang dilakukan, dan Peta pikiran ini menghubungkan berbagai macam hal menjadi satu kesatuan dalam bentuk Diagram. Ada beberapa aplikasi yang dapat membantu menggambarkan diagram peta pikiran diantaranya Freemind, Xmind, Visio dan lain - lain.

Berikut contoh hasil tampilan FreeMind 


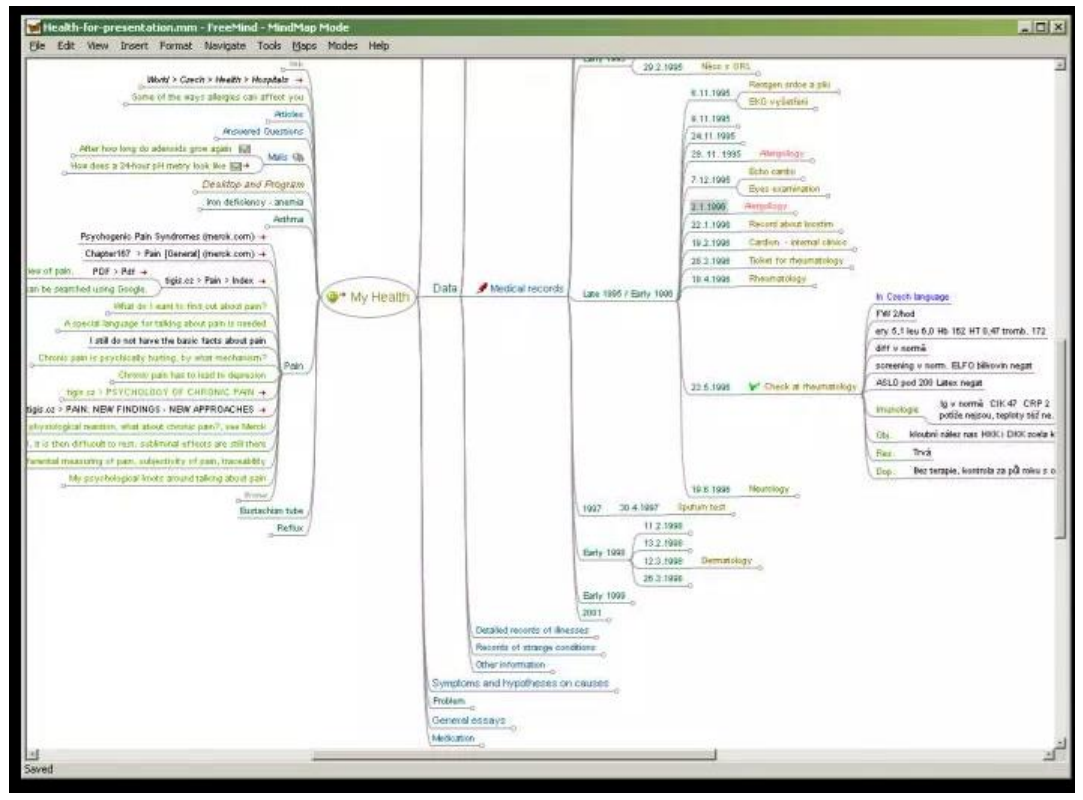

Gambar 3.7 Tampilan freemind

Sumber gambar : https://freemind.en.softonic.com/

Freemind adalah aplikasi yang digunakan untuk membuat sebuah peta pemikiran yang dapat diunduh secara gratis. Contoh aplikasi lainnya adalah Xmind. 


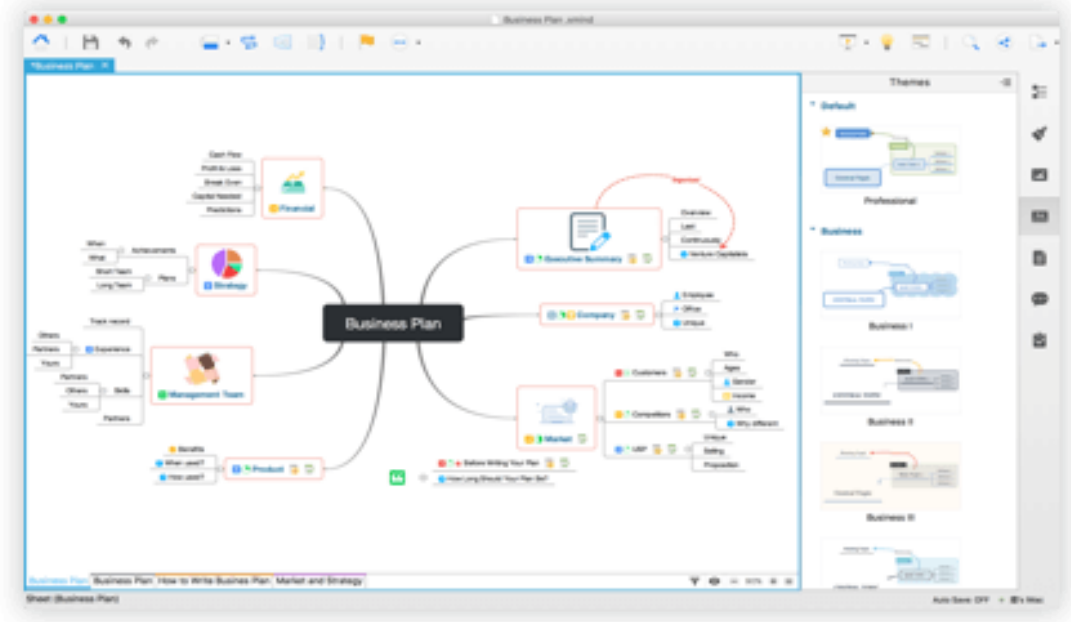

Gambar 3.8 Contoh tampilan Xmind

Sumber Gambar : https://www.xmind.net/features/

Xmind adalah aplikasi yang digunakan untuk membuat gambar diagram peta pikiran, aplikasi ini lebih komplit dibandingkan freemind.

Visio adalah aplikasi yang dapat digunakan untuk menggambar diagram salah satunya diagram peta pikiran. Visio ini merupakan paket dari microsoft office professional.

3.6. Menemukan Celah di Bidang IImu yang sedang diteliti

Setelah membuat peta pikiran langkah selanjutnya adalah menemukan celah yang akan menjadi fokus penelitian sehingga dapat disusun keaslian dari penelitian. 
(Emanuel, 2017)Terdapat beberapa langkah yang dapat dilakkan untuk menemukan celah yang akan menjadi fokus penelitian :

1. Sesuatu yang belum dipikirkan peneliti lain. Mencari sesuatu celah dengan melihat pada peta pikiran dimana terdapat "ranting" dan "cabang" yang kira - kira masih sedikit penelitian yang memikirkannya atau mungkin belum dieksplorasi oleh peneliti lainnya. Cabang atau ranting tersebut dapat menjadi sarana untuk dapat berkontribusi yang signifikan melalui penelitian yang akan ditekuni.

2. Suatu metode yang belum dicobakan oleh peneliti lain : menemukan metode - metode yang mungkin belum dicobakan atau ditemukan oleh peneliti lain. Metode baru yang diusulkan pada penelitian yang akan dilakukan apabila berhasil bisa menjadi temuan penting pada bidang tersebut.

3. Mencoba eksperimen peneliti lain dengan data baru yang berbeda. Seorang peneliti bisa melakukan suatu pengulangan atau mencoba mengulang kembali eksperimentasi dari peneliti lain namun dengan data yang berbeda. Temuan dari teknik ini bisa memperluas cakupan kesimpulan yang didapat dari penelitian sebelumnya, limitasi dari temuan sebelumnya tergantung dari temuan - temuan dari hasil eksperimentasi yang akan dilakukan.

4. Meniru dari bidang lain mungkin bisa diterapkan di bidang ini. Salah satu teknik yang dapat dilakukan adalah meniru suatu teknik atau temuan yang diketahui bekerja dengan baik di bidang ilmu 
lainnya yang kemudian ditirukan dengan bidang ilmu yang sedang diteliti.

5. Menggabungkan atau membandingkan beberapa metode, teknik atau temuan dari beberapa penelitian yang berbeda. Metode, teknik atau temuan yang ada pada penelitian yang berbeda perlu dicoba dibandingkan atau digabungkan dalam sebuah penelitian untuk melihat kekuatan dan kelemahan dari masing - masing metode, teknik atau temuan tersebut.

\subsection{Menemukan Keaslian Penelitian}

Yang dimaksud dengan keaslian penelitian adalah adanya perbedaan antara publikasi ilmiah yang dilakukan dibandingkan dengan publikasi ilmiah dari penelitian penelitian sebelumnya. Sebuah publikasi karya ilmiah yang baik aakan berusaha membarikan suatu solusi dari permasalahan yang spesifik yang berbeda dari publikasi penelitian - penelitian sebelumnya.

(Emanuel, 2017)Langkah - langkah yang dapat dilakukan dalam mencari keaslian penelitian adalah sebagai berikut :

1. Meneliti peta pemikiran . Meneliti peta pemikiran gabungan yang sudah disusun dengan seksama untuk memahami gambaran besar dari bidang ilmu penelitian dan seluruh perkembangan penelitian yang sedang dan telah terjadi pada bidang tersebut.

2. Menemukan yang belum diteliti orang lain. Menemukan bagian atau rating dari peta pikiran tersebut yang menurut kita menarik dan belum banyak yang berkontribusi pada bagian tersebut. 
3. Menemukan yang belum terpikirkan oleh orang lain. Mencoba temukan hal - hal yang mungkin belum terpikirkan oleh orang lain pada bagian dari peta pikiran yang ingin kita tekuni lebih lanjut.

\subsection{Mengelola Referensi}

Pengelolaan referensi sangat penting karena akan mempermudah dalam penggunaanya di kemudian hari. Ada beberapa cara dalam pengelolan referensi, yaitu ;

1. Mengelola referensi mengunakan Microsoft Office Word

Untuk mengelola referensi menggunakan Microsoft Office Word kita dapat menggunakan menu Reference pada toolbar.

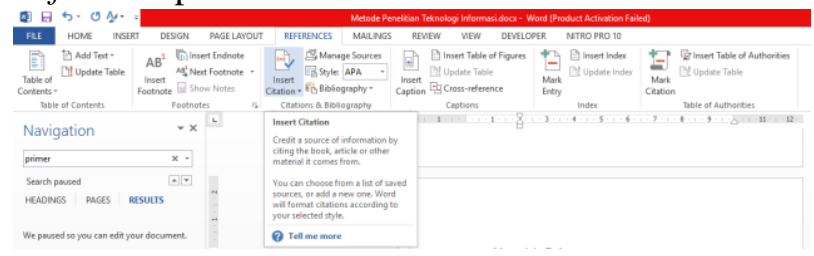

Gambar 3.9 Menu Reference pada toolbar Microsoft Office Word

Untuk menambahlan referensi baru klik icon Insert Citation kemudian klik add new source kemudian isi daftar berikut :

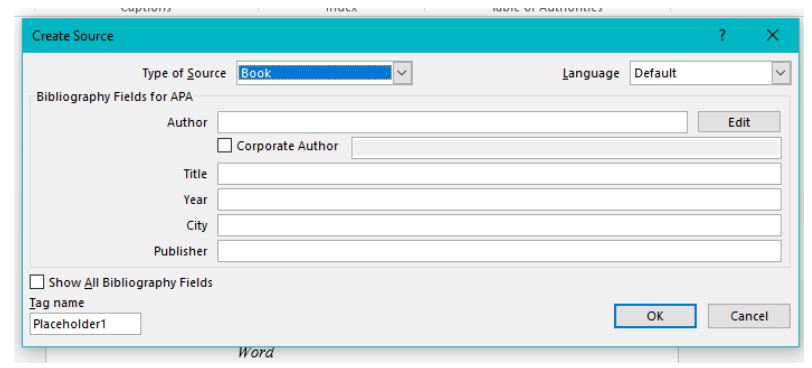


Gambar 3.10 Tampilan untuk entry data sumber referensi baru.

Citation atau sitasi didalam penulisan karya ilmiah diginakan sebagai bahan pustka pendukung untuk menunjukkan adanya kebijakan di bidang kejiannya , menerangkan suatu teori, pengertian atau definisi, untuk memperlihatkan adanya temuan dari ilmuwan lainnya, untuk memperkuat temuannya, untuk memanfaatkan metode, sebagai pembanding dimana bahan pustaka yang di review memperlihatkan adanya perbedaan atau persamaan pendapat dengan ilmuwan lainnya, dan juga untu memperkuat kesahihan penelitian yang dilakukan. Sitasi menunjukkan asal usul atau sumber suatu kutipan, mengutip pernyataan atau menyalin atau mengulang pernyataan seseorang dan mencantumkannya di dalam suatu karya tulis yang dibuat, namun tetap mengindikasikan bahwa kutipan tersebut adalah pernyataan orang lain. (Mercubuana, 2015).

Setelah mengisi data sumber referensi baru kemudian data referensi akan masuk kedalam pilihan data referensi. 


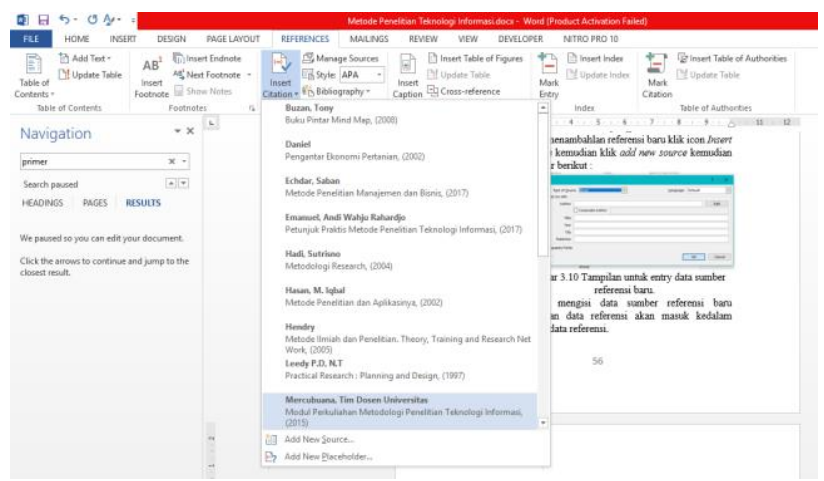

Gambar 3.11 Tampilan daftar referensi yang telah di entry

Kemudian saat membuat daftar pustaka pada laporan, dapat dilakukan dengan memilih menu "Bibliography" dan memilih tampilan daftar pustaka yang sesuai.

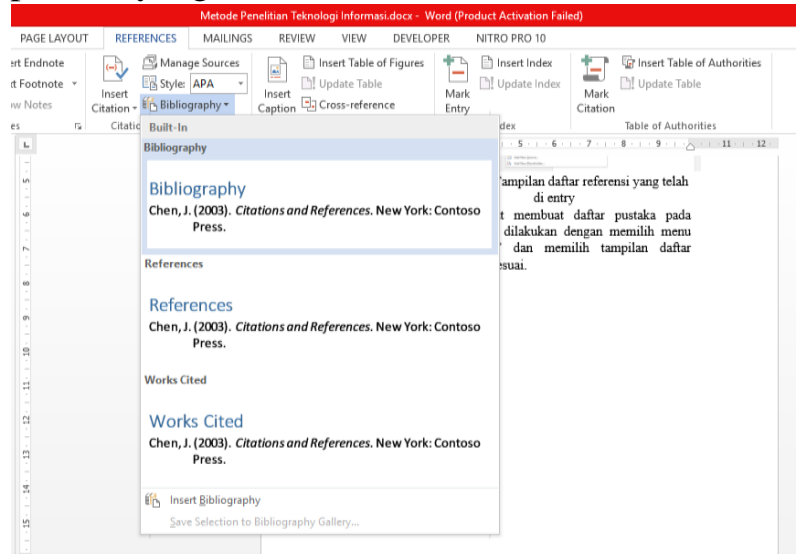

Gambar 3.12 Contoh pilihan Bibliography

2. Mengelola Referensi dengan Mendeley salah satu alternatif yang dapat dilakukan untuk untuk mengelola referensi adalah dengan 
menggunakan aplikasi Mendeley. Mendeley ini dapat diterapkan pada Microsoft Office Word . untuk penerapannya sama dengan pengelolaan menggunan Microsoft Office Word Sebelumnya. Berikut tampilan dari situs Mendeley.

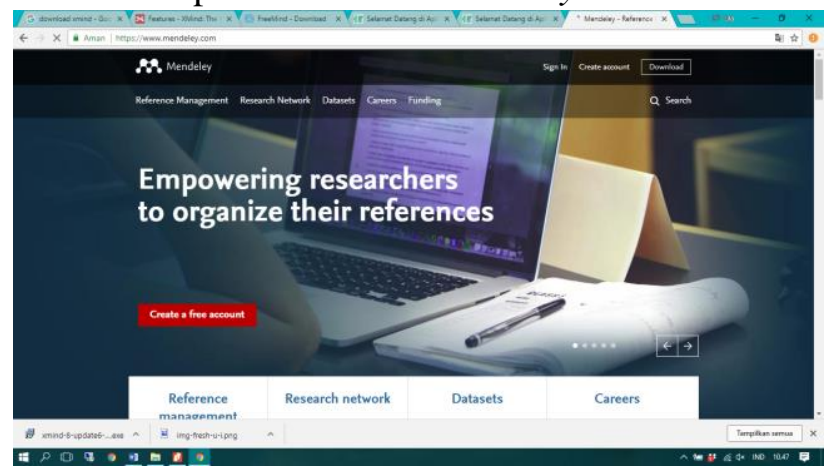

Gambar 3.13 Tampilan situs Mendeley

Untuk dapat menggunakan fasilitas Mendeley ini , pengguna harus membuat account terlebih dahulu.

\subsection{Penyusunan Kajian Pustaka}

Menurut Wiratna dalam (Echdar, 2017) langkah yang dilakukan dalam penyusunan kajian pustaka, adalah sebagai berikut :

1. Menyiapkan butir - butir yang perlu dalam mencatat informasi dari pustaka.

2. Menyiapkan sistematika pengumpulan informasi.

3. Mencari informasi sebanyak - banyaknya dari bahan kepustakaan maupun internet.

Sedangkan menurut Ary, Donald dan Creswell dalam (Echdar, 2017) sintesis dari langkah - langkah penyusunan kajian pustaka adalah sebagai berikut : 
1. Mulailah dengan mengidentifikasi kata kunci topik penelitian untuk mencari materi, referensi dan bahan pustaka yang terkait.

2. Membaca abstrak laporan - laporan hasil penelitian yang relevan, bisa didapat dari sumber perpustakaan, jurnal, buku dan prosiding.

3. Membuat catatan hasil bacaan dengan membuat peta literatir urutkan dan keterkaitan topik penelitian dan referensi bibliografi secara lengkap.

4. Membiat ringkasan literatur secara lengkap berdasarkan peta literatur, sesuai dengan urutan dan keterkaitan topik pada setiap variabel penelitian.

5. Membuat kajian pustaka dengan menyusunnya secara tematis berdasarkan teori - teori dan konsepkonsep penting yang berkaitan dengan topik dan variabel penelitian.

6. Pada akhir kajian pustaka, kemukakan pandangan umum tentang topik penelitian yang dilakukan berdasarkan literatur yang ada, dan jelaskan orisinalitas dan pentingnya topik penelitian yang akan dilakukan dibandingkan dengan literatur yang sudah ada.

Berdasarkan pemaparannya, menurut Ratna dalam (Prastowo, 2012) penyajian kajian pustaka dibedakan menjadi dua macam :

1. Penyajian kajian pustaka secara deskriptif, yaitu hanya menguraikan tanpa menyebutkan persamaan dan perbedaannya dengan pertimbangan bahwa analisis akan diuraikan pada bab berikutnya.

2. Penyajian kajian pustaka secara deskriptif dengan analisis yaitu selain bentuk deskripsi, juga disertai 
penjelasan tentang perbedaan dan persamaanya. Dengan demikian kajian pustaka menunjukkan dimana posisi peneliti dalam kaitannya dengan penelitian yang sudah pernah dilakukan, apakah menolak, mengkritik, menerima dan atau lainnya.

\subsection{Proses Telaah Pustaka}

Menurut (Echdar, 2017) Langkah - langkah penting dalam melakukan telaah pustaka adalah sebagai berikut :

1. Cari jenis literatur yang sesuai.

2. Cari naskah dari publikasi yang sesuai.

3. Cari naskah dengan variabel yang sesuai

4. Buatkah ringkasan dari pemikiran ilmuwan atau peneliti yang dirujuk.

5. Bahaslah dan jelaskan subtansi dari konsep atau konstruk penelitian yang digunakan dalam penelitian.

6. Temukanlah berbagai pro dan kontra terhadap isu maupun konsep yang dikembangkan untuk penelitian yang dilakukan, sehingga dari situ dapat dihasilkan sebuah pemikiran baru.

7. Kembangkan proposisi dan grand theoritical model.

8. Kembangkan hipotesis dan emprical research model.

\subsection{Pengembangan Teori}

Teori memiliki tujaun untuk memberikan gamabran tentang suatu fenomena. Proses mengembangkan teori ditentukan oleh pengkajian pustaka yang telah dilakukan. Dari pengkajian pustaka tersebut 
memunculkan model teoretical dasar maupun model penelitian empiris.

Jadi untuk mengembangkan sebuah teori, seorang peneliti harus mengembangkan beberapa porposisi untuk menjelaskan fenomena yang ada. Proposisi dikembangkan dari berbagai konsep yang relevan dengan bidang ilmu yang diminati oleh peneliti.

Menurut (Nazir, 2011) Proposisi adalah pernyataan tentang sifat dari realita. Proposisi dapat diuji kebenarnnya . Jika proposisi sudah dirumuskan sedemikian rupa dan sementara diterima untuk diuji kebenarnnya, proposisi tersbeut disebut hipotesis.

\subsection{Pengembangan Model}

Menurut Naert dan Leeflang dalam (Echdar, 2017) menyatakan bahwa " A model is a representation of the most important elements of a perceived real world system". Sebuah model berfungsi memberikan gambaran terstruktur sehingga fenomena nyata dalam masyarakat dapat dipahami dan dianalisis.

Ada beberapa hal yang perlu dipertimbangkan oleh seorang peneliti dalam mengembangkan sebuah model yaitu :

1. Tentukan tujuan utama sebuah model

Suatu model dapat dikembangkan untuk menjawab masalah penelitian.

2. Rumusan alur - alur logik (logical-parth Diagram) Untuk memecahkan masalah penelitian, peneliti dapat mulai dengan menggabarkan alur logik yang akan digunakan untuk menjelaskan masalah penelitian tersebut. 
3. Model yang telah dinyatakan dalam sebuah diagram , dirumuskan kembali dalam bentuk model - model matematika, statistik sebagai sebuah langkah untuk memudahkan analisis serta pengujian .

\subsection{Jenis - jenis Model}

Menurut tujuannya model dapat dibedakan atas dua model yaitu :

1. Model deskriptif, model deskriptif ditujukan untuk mendeskripsikan sebuah situasi atau serangkaian proses. Model deskriptif digunakan untuk menjawab pertanyaan penelitian dari sebuah masalah penelitian yang dikembangkan untuk dianalisis dengan teknik - teknik seperti model frekuensi, analisis faktor eksploratori dan analisis faktor konfirmatori.

2. Model prediktif, digunakan untuk tujuan peramalan masa yang akan datang.

\subsection{Elemen Pengembangan Model}

Dalam pemodelan terdapat terdapat tiga langkah utama yang harus dilakukan yaitu (Echdar, 2017) :

1. Spesifikasi atau penyusunan struktur model

Pada tahap ini sebuah model di sajikan dalam statistik yang dinyatakan secara visual dalam bentuk gambar atau diagram.

2. Parameterisasi atau estimasi model

Peneliti menentukan parameter dari model yang digunakan . langkah yang dilakukan adalah penentuan jenis data yang dibutuhkan dan pengumpulan data. 
3. Validasi, verifikasi model

Pada tahap ini dilakukan penilaian dari model yang telah dikembangkan.

\subsection{Parameterisasi Model}

Beberapa alat yang digunakan untuk menganalisi model adalah (Echdar, 2017) :

1. Model Regresi

Model regresi adalah model yang digunakan untuk menganalisi beberapa variabel independen terhadap satu variabel dependen.

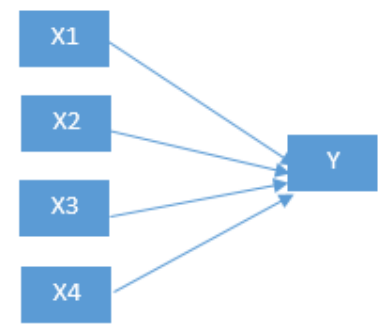

Gambar 3.14 Model Regresi

Model diatas menunjukkan bahwa variavel $\mathrm{Y}$ dipengaruhi secara bersama - sama maupun sendiri - sendiri oleh variabel X.

2. Model Regresi Moderasi

Yaitu model dimana satu atau beberapa variabel independen mempengaruhi satu variabel dependen dengan syarat pengaruhnya akan lebih kuat atau lemah bisa sebuah variabel yang lain tempil sebagai variabel moderasi. 


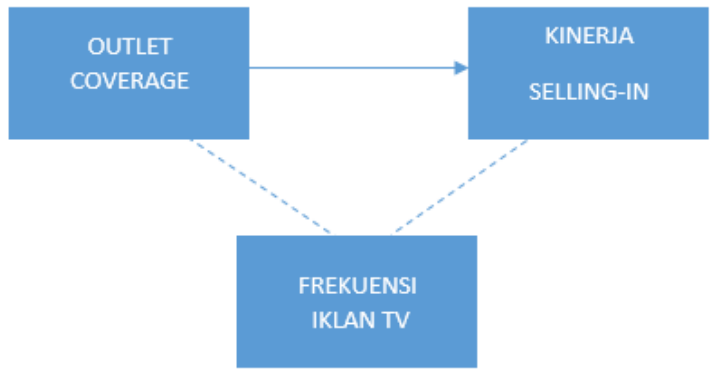

Gambar 3.15 Model Regresi Moderasi

3. Model Jalur

Model struktural yang hanya menggunakan observed variabel, tanpa menggunakan latent variabel disebut Path Analysis Model, menggambarkan model - model kausal berjenjang. Model path analysis ini dapat dianalisis dnegan menggunakan program AMOS.

4. Model analisi faktor konfirmatori

Analisi ini digunakan untuk mengkonfirmasi faktor - faktor yang dibentuk untuk mendefinisikan sebuah konsep atau konstruk penelitian.

5. Model Persamaan Struktural

Model SEM adalah sebuah model kausal berjenjang yang mencakup dua jenis variabel utama yaitu variabel laten serta variabel observasi.

6. Model Komparatif

Model komparatif dibagi menjadi dua yaitu :

a. Model uji perbedaan atas kegiatan

Salah satu model uji perbedaan adalah berupa uji perbedaan untuk mendapatkan gambaran deskriptif ats adanya tindakan 
tertentu yang diharapkan memberi dampak tertentu.

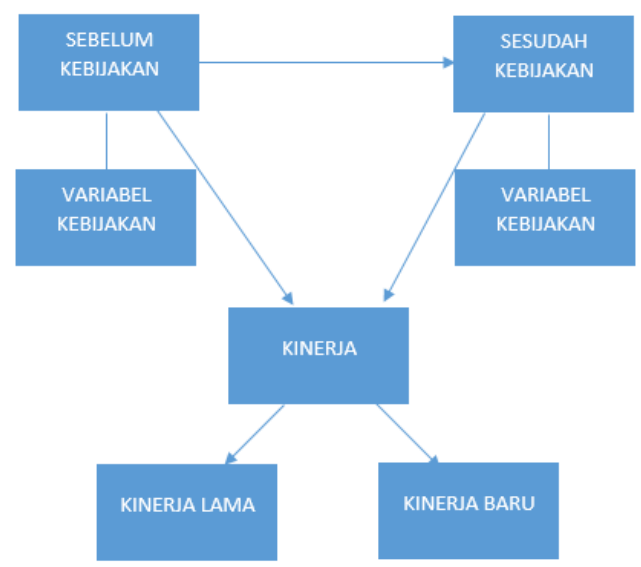

Gambar 3.16 Model uji perbedaan kegiatan

b. Model uji perbedaan atas status

Model ini mengukur perbedaan yang muncul bukan karena adanya tindakan tertentu, tetapi karena posisi atau status tertentu dimiliki oleh sebuah objek pengamatan. 


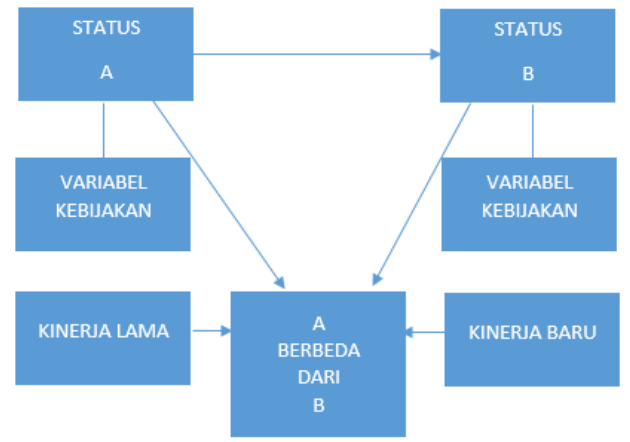

Gambar 3.17 Model uji perbedaan status

\subsection{Penelitian Terdahulu}

Penelitian terdahulu digunakan untuk acuan dan pendukung dalam melakukan penelitian. Dalam melakukan penelitian, peneliti minimal mereview 3 penelitian terdahulu yang sejenis, kemudian dirangkum dalam sebuah paragraf dan dianalisis apa yang membedakan dengan penelitian yang akan dilakukan. 
Penguatan materi !

1. Carilah buku - buku yang terkait dengan topik penelitian yang anda pilih .

2. Buat database rujukan tentang kajian pustaka yang terkait dengan topik yang anda pilih. Kemudian telaah dari setiap pustaka yang telah anda temukan, kemudian buat sistesis dari setiap definisi yang anda kumpulkan.

3. Carilah beberapa penelitian terdahulu yang terkait dengan topik penelitian yang anda pilih.

4. Carilah celah yang menjadi pembeda antara penelitian anda dengan penelitian yang telah dilakukan peneliti terdahulu. 


\section{BAB IV DESAIN PENELITIAN}

Desain penelitian merupakan sebuah rencana strategis yang sistematis dan prosedural yang menjadi panduan bagi peneliti untuk menjawab dari pertanyaan atau permasalahan penelitian. Rencana tersebut merupakan skema atau program lengkap dari sebuah penelitian. Skema tersebut mulai dari perumusan hipotesis yang berimplikasi pada cara, prosedur penelitiannya dan pengumpulan data serta analisis data. Melalui sebuah penelitian seorang peneliti dapat melakukan hal berikut (Echdar, 2017) :

1. Mengkonsepkan rencana operasional untuk menjalankan berbagai prosedur dan tugas yang diperlukan untuk menyempurnakan studi.

2. Memastikan bahwa prosedur - prosedur tersebut sesuai dan layak untuk memperoleh jawaban dari pertanyaan atau permasalahan penelitian secara valid obyektif dan akurat

3. Menjabarkan secara lengkap bagaimana peneliti hendak melakukan penyelidikan untuk menjawab pertanyaan pertanyaan penelitian, sehingga memudahkannya dalam pelaksanaan penelitian.

4. Dengan desain penelitian memungkinkan orang lain memahami dan mengikuti langkah - langkah yang hendak dijalankan oleh peneliti dalam menemukan jawaban.

\subsection{Fungsi Desain Penelitian}

Berdasarkan pengertian desain penelitian, ada beberapa fungsi pokok dari desain penelitian yaitu :

1. Sebagai blueprint bagi peneliti 
Peneliti akan mengalami banyak kendala jika peneliti tidak menyusun rencana sebelum melakukan penelitiannya

2. Menetapkan batasan dari kegiatan penelitian dan memungkinkan peneliti untuk menyalurkan energinya dalam beberapa arah yang spesifik, disebut spesifik karena sudah jelas arah dan langkahnya karena sudah disusun desainya.

3. Untuk mengantisipasi masalah yang mungkin timbul dalam proses penelitian.

Kualitas dari sebuah penelitian bergantung pada rancangan desain penelitian yang di susun oleh peneliti.

\subsection{Hal - hal Penting Terkait Desain Penelitian}

Penelitian yang baik perlu dirancang aktivitas dan sumber dayanya dengan baik. Desain penelitian adalah rencana dari struktur penelitian yang mengarahkan proses dan hasil penelitian sedapat mungkin menjadi valid, obyektif, efisien dan efektif (Echdar, 2017). Menurut Cooper dan Schindler dalam (Echdar, 2017) ada beberapa hal yang perlu diperhatikan dalam desain penelitian yaitu sebagai berikut :

1. Desain penelitian adalah perencanaan aktivitas dan waktu

2. Desain penelitian selalu didasarkan pada pertanyaan atau topik penelitian

3. Desain penelitian mengarahkan ke pemilihan sumber daya dan tipe informasi yang diperlukan

4. Desain penelitian merupakan suatu kerangka untuk menunjukkan hubungan antara variabel - variabel yang akan diteliti 
5. Desain penelitian menggariskan langkah - langkah untuk menyiapkan aktivitas penelitian.

\subsection{Faktor yang Mempengaruhi Desain Penelitian}

Ada sejumlah faktor yang perlu diperhatikan dalam membuat desain penelitian, yaitu sebagai berikut :

1. Penentuan judul penelitian

Judul penelitian berfungsi untuk mengetahui obyek penelitian, subyek apa yang akan diteliti, dimana lokasi penelitian, tujuan yang ingin dicapai dan sasarannya.

2. Penentuan masalah

Masalah penelitian merupakan pedoman bagi kegiatan penelitian. Masalah penelitian berperan dalam mengarahkan penelitian.

3. Penentuan Tujuan Penelitian

Tujuan penelitian dapat mengarahkan peneliti untuk mencapai sasaran dan target yang ingin dicapai.

4. Penentuan hipotesis

Hipotesis adalah jawaban sementara terhadap permasalaan, namun perlu menguji kebenarannya.

5. Penentuan populasi dan sample penelitian

Yang harus diperhatikan dalam menentukan sampel penelitian adalah populasi didaerah penelitian, jumlah sample yang akan diteliti, dan metode pengambilan sample.

6. Penentuan metode dan teknik pengumpulan data Ada beberapa metode pengumpulan data yaitu observasi, wawancara, angket atau kuesioner.

7. Penentuan cara mengolah dan menganalisis data 
Penguatan materi !

1. Buatlah blueprint atau desain penelitian dari penelitian yang akan anda lakukan . 


\section{BAB V VARIABEL PENELITIAN DAN PENGUKURANNYA}

\subsection{Variabel Penelitian}

Variabel dalam penelitian bertujuan sebagai landasan untuk mempersiapkan alata dan metode pengumpulan data, dan sebagai alat untuk menguji hipoteisis, oleh sebab itu variabel sangat penting dalam penelitian.

(Echdar, 2017)Variabel adalah segala sesuatu yang berbentuk apa saja yang ditetapkan oleh peneliti untuk dipelajari sehingga diperoleh informasi tentang suatu hal, kemudain ditarik kesimpulan. Dalam sebuah penelitian variabel memiliki ciri khusus yaitu memiliki variasi nilai, membedakan satu obyek dengan obyek yang lain dalam satu populasi dan dapat diukur.

\subsection{Jenis - jenis Variabel}

(Echdar, 2017)Berdasarkan hubungan antarvariabel, variabel dalam sebuah penelitian dapat dikelompkkan menjadi berikut :

1. Variabel Independen

Variabel Independen atau bebasa adalah variabel yang mempengaruhi atau menjadi penyebab terjadinya perubahan pada variabel lain sehingga dapat dikatakan bahwa perubahan yang terjadi pada variabel ini diasumsikan akan mengakibatkan terjadinya perubahan pada variabel lainnya. 


\section{PRESTASI BELAJAR}

MAHASISWA

Gambar 5.1 Variabel Independen

2. Variabel Dependen

Variabel dependen atau terikat adalah variabel yang keberadaannya dipengaruhi atau menjadi akibat karena adanya variabel bebas.

Gambar 5.2 Variabel dependen

3. Variabel Moderator

Variabel moderator merupakan variabel yang memperkuat ataupun memperlemah pengaruh variabel bebas terhadap variabel terikatnya.
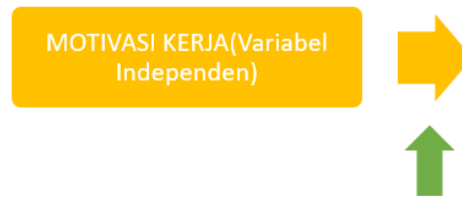

\section{KINERJA PERUSAHAAN \\ (Variabel dependen)}

INTELEGENSI (IQ)

(Variabel Moderator)

Gambar 5.3 Variabel Moderator

4. Variabel Intervening (Antara)

Variabel Intervening atau variabel anatara merupakan variabel yang secara teoritis mempengaruhi hubungan antara variabel bebas terhadap variabel terikat menjadi hubungan yang tidak langsung dan tidak dapat diamati dan diukur. 


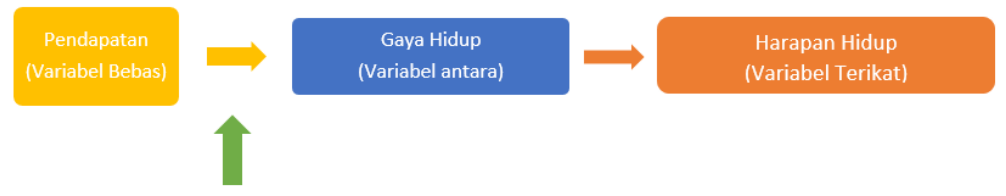

Budaya Lingkungan Hidup

(Variabel Moderator)

Gambar 5.4 Variabel antara

5. Variabel Kontrol

Variabel kontrol meruapakan variabel yang dibatasi atau dikendalikan pengaruhnya sehingga tidak berpengaruh terhadap yang sedang diteliti.

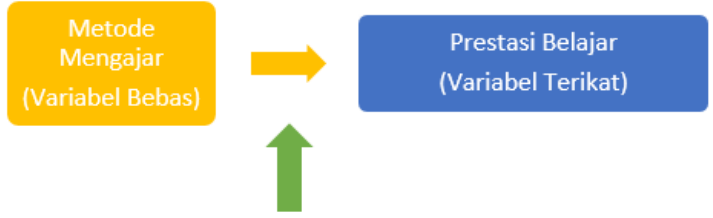

\section{Mata Kuliah}

(Variabel Kontrol)

Gambar 5.5 Variabel kontrol

\subsection{Hubungan antar Variabel}

Terdapat dua hubungan antarvariabel bebas dan variabel terikat yaitu (Echdar, 2017):

1. Hubungan simetris

Variabel - variabel dikatakan mempunyai hubungan simetris apabila variabel yang satu tidak disebabkan atau dipengaruhi oleh variabel alinnya.

2. Hubungan timbal balik 
Hubungan timbal balik adalah hubungan dimana suatu variabel dapat menjadi sebab dan akibat variabel lainnya. Perlu dikaetahui bahwa hubungan timbal balik bukanlah hubungan, dimana tidak dapat ditentukan variabel yang menjadi sebab dan variabel yang menjadi akibat.

3. Hubungan Asimetris

Satu variabel atau leih mempengaruhi variabel lainnya.

\subsection{Pengukuran Variabel}

Dalam penelitian pengukuran sangat berperan penting karena pengukuran dapat mengubungkan antara konsep dengan realitas yang ada. Untuk dapat melakukan pengukuran maka peneliti harus menentukan ukuran yang tepat pada sebuah konsep. Menurut (Echdar, 2017)proses pengukuran mengandung empat kegiatan pokok sebagai berikut :

1. Menentukan indikator untuk dimensi - dimensi variabel penelitian

2. Menentukan ukuran masing - masing dimensi. Ukuran ini dapat berupa item (pertanyaan) yang relevan dengan dimensinya.

3. Menentukan ukuran yang akan digunakan dalam pengukuran, apakah tingkat ukuran nominal , ordinari interval atau rasio

4. Menguji tingkat validitas dan reabilitas sebagai kriteria alat pengukuran yang baik.

\subsection{Skala Pengukuran Variabel}

Menurut Stevens dalam (Echdar, 2017) mengemukakan bahwa pengukuran adalah penetapan atau pemberian angka terhadap objek atau fenomena menurut 
aturan tertentu. Skala pengukuran merupakan kesepakatan yang dijadikan acuan untuk menentukan ukuran interval yang ada dalam alat ukur, sehingga alat ukur tersebut jika digunakan dalam pengukuran akan menghasilkan data kuantitatif.

Berikut adalah berbagai skala pengukuran yang digunakan dalam penelitian :

1. Skala Likert

Skala likert digunakan untuk mengukur sikap , pendapat atau persepsi oranglain dalam sekelompok atau fenomenas sosial yang dalam setiap jawaban pada setiap instrumen terdapat gradasi dari sangat posistif sampai sangat negatif. Contoh jawaban instrumen yang menggunakan skala likert.

Sangat tidak setuju $\quad=1$

Tidak setuju $\quad=2$

Tidak tahu $\quad=3$

Setuju $\quad=4$

Sangat setuju $\quad=5$

Instrument dalam skala Likert dapat berupa checklist atau pilihan ganda

2. Skala Guttman

Pengukuran dengan menggunakan skala guttaman akan mendapatkan jawaban yang tegas karena jawaban dari setiap instrumen hanya terdiri "ya tidak" , "benar - salah", dan lain - lain.

3. Skala lain seperti semantik diferensial, rating scale, trustone scale 


\subsection{Jenis Pengukuran Variabel}

Secara umum terdapat empat jenis pengukuran yaitu :

1. Ukuran nominal

Ukuran nominal merupakan ukuran yang membedakan kategori berdasarkan jenisnya.

2. Ukuran ordinal

Ukuran ordinal merupakan ukuran yang membedakan kategori berdasarkan jenis dan tingkatannya.

3. Ukuran interval

Ukuran interval merupakan ukuran yang memiliki jarak yang sama antara satu objek denan lainnya serta jarak tersebut dapat diketahui secara pasti.

4. Ukuran rasio

Ukuran rasio adalah ukuran yang memberikan arti perbandingan atau perkalian.

Penguatan materi !

1. Tentukan variabel dan hubungan antar variabel dari penelitian yang anda lakukan .

2. Buatlah dimensi dan indikator dari setiap variabel, dari penelitian yang anda lakukan.

3. Tentukan cara pengukurannya dan skala pengukurannya. 


\section{BAB VI POPULASI DAN SAMPEL}

\subsection{Populasi}

Untuk mengambil sebuah data dan menguji hipotesis seorang peneliti harus meneliti seluruh populasi dan mengambil bagian kecil dari populasi untuk di amati.

Menurut (Echdar, 2017) Populasi diartikan sebagai kumpulan objek penelitian dari mana data akan di jaring dan kumpulkan. Populasi adalah keseluruhan atau totalitas objek yang diteliti yang ciri - cirinya akan diduga atau di taksir. Ciri - ciri populasi disebut dengan parameter.

Menurut (Arikunto, 2010) populasi merupakan seluruh data yang menjadi pusat perhatian seoarang peneliti dalam ruang lingkup dan waktu yang telah ditentukan. Populasi berkaitan dengan data - data. Jika setiap manusia memberikan suatu data, maka ukuran atau banyaknya populasi akan sama dengan banyaknya manusia.

Menurut (Nazir, 2011)populasi ialah sekumpulan individu - individu dengan kualitas dan karakter yang sudah ditetapkan oleh peneliti. Ciri atau kualitas itu yang dinamakan variabel. Ia membagi populasi yaitu populasi finit dan infinit.

Dari definisi diatas dapat disimpulkan bahwa populasi adalah objek atau subjek yang berada pada suatu wilayah yang memenuhi syarat - syarat tertentu yang berkaitan dengan masalah penelitian. Elemen atau unsur dari populasi adalah anggota dari populasi yang diamati 
sedangkan bingkai dari populasi adalah daftar dari semua elemen atau unsur dalam populasi .Menurut Margono dalam (Echdar, 2017)populasi dibedakan menjadi dua :

1. Populasi teoretis yaitu populasi yang batasannya ditetapkan secara kualitatif

2. Populasi yang tersedia yaitu populasi yang secara kuantitatif bisa dinyatakan dengan tegas dan tepat.

Sedangkan berdasarkan sifatnya populasi terbagi menjadi populasi homogeny dan populasi heterogen. Populasi homogeny adalah populasi yang unsurnya memiliki sifat yang sama tidak mempersoalkan jumlahnya secara kuantitatif. Sedangkan populasi heterogen adalah populasi yang memiliki sifat yang berbeda sehingga memerlukan batasan baik kualitatif maupun kuantitatif

\subsection{Sampel}

Menurut (Arikunto, 2010) mengemukakan bahwa sampel adalah bagian dari populasi . Sedangkan sampel penelitian adalah sebagian populasi yang diambil sebagai sumber data dan dapat mewakili seluruh populasi.

Menurut Augusty dalam (Echdar, 2017) proses bagaimana memilih jumlah elemen yang cukup dari suatu populasi yang memungkinkan proses generalisasi hasil penelitian disebut sampling. Untuk melakukan sampling, seorang peneliti menurut Augusty akan melakukan proses sampaling. Berikut gambaran proses sampling. 


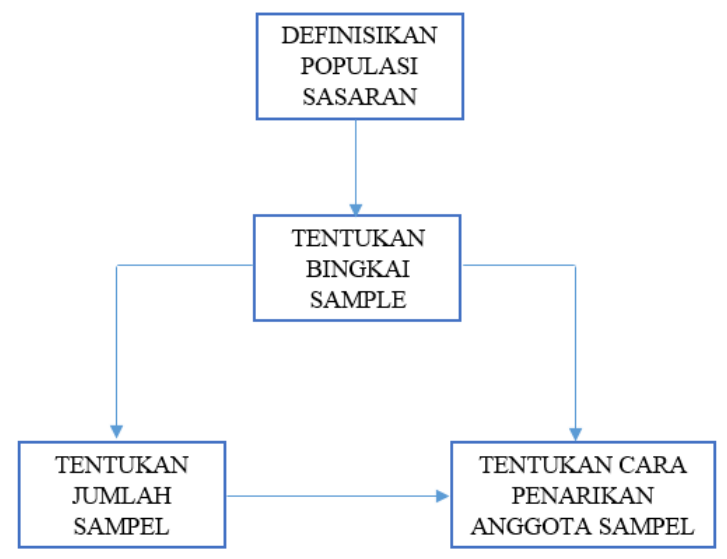

Gambar 6.1 Proses desain sampling

Menurut (Echdar, 2017)ada empat parameter yang bisa dianggap menentukan representativness sample (sample yang benar - benar mencerminkan populasinya) :

1. Variabilitas populasi

Variabilitas populasi merupakan sudah "given" artinya peneliti harus menerima sebagaimana adanya, dan tidak dapat mengatur atau memanipulasinya.

2. Besar sampel

Makin besar sampel yang diambil akan semakin besar atau tinggi taraf representativness sampel tersebut. Jika populasinya homogen secara sempurna besarnya sampel tidak mempengaruhi taraf representativness sampel.

3. Teknik penentuan sampel 
Makin tinggi tingkat ambang dalam penentuan sampel, akan makin tinggi pula tingkat representativness sampel.

4. Kecermatan memasukkan ciri - ciri populasi dan sampel.

Makin lengkap ciri - ciri populasinya yang dimasukkan ke dalam sampel, akan makin tinggi tingkat representativness sampel.

(Echdar, 2017)contoh praktik pengambilan sampel yang banyak digunakan dalam penelitian adalah sebagai berikut :

1. Jika ukuran populasinya diketahui dengan pasti, Rumus Slovin dapat digunakan

$$
n=\frac{N}{1+N e^{2}}
$$

Keterangan :

$n$ = ukuran sampel

$N=$ ukuran populasi

$e=$ kelonggaran ketidak telitian karena kesalahan pengambilan sampel yang ditolerir, misalnya 5\%

2. Jika ukuran populasinya besar yang didapat dari pendugaan proporsi populasi, maka Rumus Yamane yang harus digunakan.

$$
n=\frac{N}{N d^{2}+1}
$$

$d=$ batas toleransi kesalahan pengambilan sampel yang digunakan.

Misalnya, kita ingin menduga proporsi pembaca kkoran dari populasi 4.000 orang . presisi ditetapkan di antara 5\% dengan tingkat kepercayaan 95\%, maka besarnya sampel adalah : 


$$
n=\frac{4000}{4000 \times(0,05)^{2}+1}=364
$$

\subsection{Syarat - Syarat Sampel yang Baik}

Sampel yang baik adalah sampel yang dapat mewakili populasinya. Ada dua kriteria sampel yang baik , yakni sebagai berikut :

1. Akurat

Sampel yang baik harus akurat atau tidak bias. Ada beberapa cara agar supaya tidak biasa adalah dengan memilih sampel berdasarkan proksi yang tepat artinya mengelompokkan berdasarkan grupnya dan dengan menghindari bias diseleksi sample.

\section{2. $\quad$ Presisi}

Semakin tinggu presisi sampel maka semakin rendah eror dari pengambilan sampel tersebut

Menurut Gay dalam (Echdar, 2017) mengatakan bahwa untuk penelitian deskriptif , sampel minimum adalah $10 \%$ - 20\% dari populasi. Untuk penelitian kolerasi paling tidak 30 subjek . Untuk riset percobaan paling sedikit 30 orang per kelompok. Sedangkan McMilan dan Schumacher dalam (Echdar, 2017) berpendapat bahwa untuk penelitian kolerasioal, sampel minimum adalah 30 orang. Sedangkan untuk perbandingan diperlukan paling tidak 10 orang dalam tiap kelompok.

\subsection{Teknik Pengambilan Sampel}

Ada banyak teknik pengambilan sampling yang digunakan untuk menentukan sampel dalam penelitian. Pengelompokan teknik pengambilan sampling dapat digambarkan sebagai berikut : 


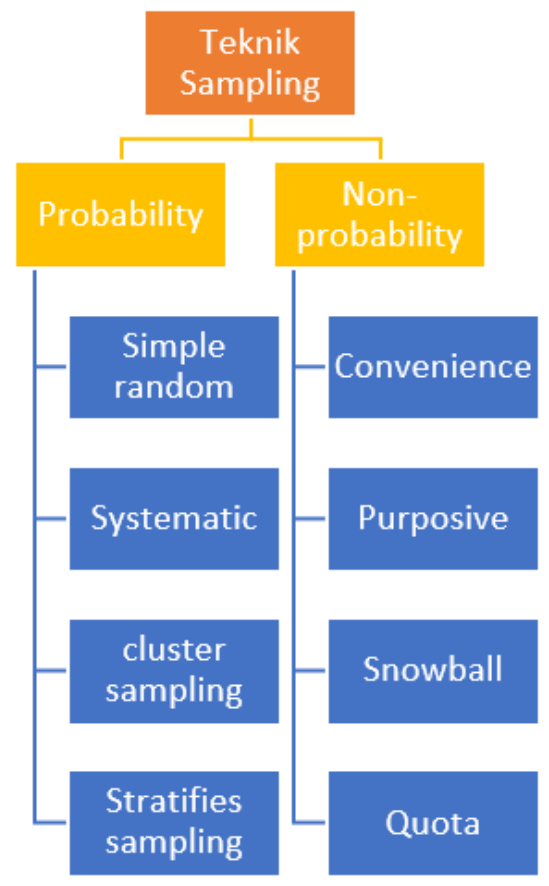

Gambar 6.2 Pengelompokan teknik pengambilan sampel

Berikut adalah penjelasan dari pengelompokan teknik pengambilan sample menurut (Echdar, 2017) :

1. Probability Sampling

Probability sampling adalah teknik pengambilan sampel yang memberikan peluang yang sama bagi setiap unsur (anggota) populasi untuk dapat dipilih menjadi anggota sampel. Teknik probability sampling terdiri atas :

a. Simple Random Sampling (sample acak sederhana) 


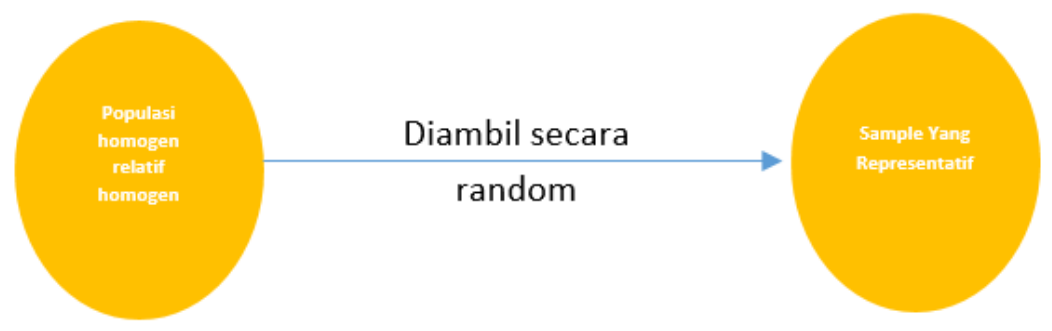

Gambar 6.3 Sample random sampling b. Systematic Random Sampling (sampling acak sistematis)

Merupakan rancangan sampling yang memiliki karakteristik bahwa unsur yang pertama dipilih secara random pada interval antara 1 dan N/n. Kemudian unsur-unsur yang lain disesuaikan dengan rasio (N/n).

c. Stratified Random Sampling (Sampling acak bertingkat/Strata)

Merupakan rancangan sampling yang memiliki karakteristik bahwa terdapat pembagian populasi ke dalam beberapa kelas, kategori, atau kelompok.

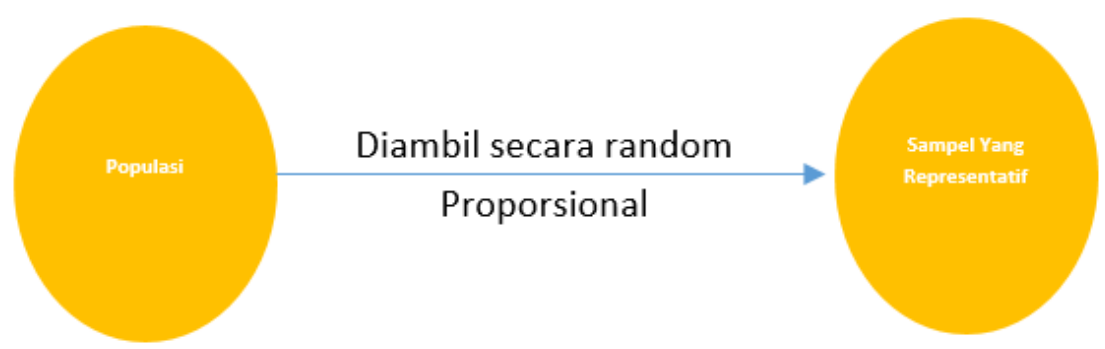


Gambar 6.4 Teknik propostionate stratified random sampling

d. Cluster Sampling (Sampling kelompok /klaster)

Merupakan rancangan sampling kelompok dan dilakukan jika terdapat kelompok alamiah dalam populasi.

2. Non-probability Sampling

Nonprobability sampling merupakan kebalikan dari teknik probability sampling, yakni tidak memberikan peluang yang sama bagi setiap unsur atau anggota populasi untuk dipilih menjadi sample. Teknik sampel ini meliputi :

a. Sampling sistematis

Teknik pengambilan sampel berdasarkan urutan dari anggota populasi yang telah diberi nomor urut terlebih dahulu.

b. Sampling kuota

Teknik pengambilan sampel yang populasinya memiliki ciri - ciri tertentu sampai jumlah kuota yang diinginkan oleh peneliti terpenuhi.

c. Sampling insidental

Teknik pengambilan sampel berdasarkan kebetulan, yakni siapa saja yang secara kebetulan bertemu dengan peneliti dapat dipakai sebagai sampel.

d. Sampling purposif

Teknik penentuan sampel dengan pertimbangan tertentu yakni seleksi khusu.

e. Sampling jenuh 
Teknik pengambilan sampel yang digunakan pada populasi yang semua anggotanya digunakan sabagai sampel

f. Sampling snowball

Teknik pengambilan sampel dimana jumlah sampel mula - mula kecil atau sedikit, lalu kemudian membesar.

\subsection{Teknik Pengambilan Sampel}

Menurut Davis dan Cosenza ; Zikmund dalam (Kuncoro, 2013) menyebutkan tahapan proses pemilihan sampel terdiri dari :

1. Penentuan populasi

2. Penentuan unit pemilihan sampel

3. Penentuan kerangka pemilihan sampel

4. Penentuan desain sampel

5. Penentuan jumlah sampel

6. Pemilihan sampel

Penguatan materi !

1. Tentukan populasi dan sampel untuk menguji hipotesi. 


\section{BAB VII SUMBER DATA DAN PENGUMPULAN DATA}

Penelitian tanpa data maka penelitiannya tidak akan berhasil, penelitian sangat bergantu pada data yang diperoleh dan data yang dianalisi atau diolah. Ada beberapa hal yang perlu diperhatikan dalam pengelolaan data penelitian adalah ketersediaan data, tipe data, sumber data dan pengumpulan data.

\subsection{Ketersediaan Data}

Ada beberapa hal yang perlu dipertimbangkan dalam memulai sebuah penelitian pada suatu topik atau subtopik yang berkaitan dengan data antara lain (Emanuel, 2017) :

1. Jumlah data harus cukup banyak

Jumlah data yang tersedia untuk diteliti haruslah cukup banyak untuk diolah dan dianalisa. Besaran "banyak" disini sangatlah relatif. Suatu penelitian akan mengalami hambatan yang cukup berarti apabila jumlah data yang terkumpul terlalu sedikit. Penelusuran perlu dilakukan dengan melihat komparasi data yang diolah pada penelitian penelitian sejenis untuk menentukan jumlah data yang dianggap sesuai dan pantas.

2. Tidak semua data bisa dipergunakan Meskipun data yang sudah terkumpul dan dapat dikumpulkan sudah cukup banyak, perlu diketahui bahwa tidak semua data bisa dipergunakan dalam sebuah penelitian. Untuk itu saat mencari sumber sumber data potensial untuk penelitian, hal tersebut 
harus selalu diingat sehingga saat mengumpulkan data perlu dikumpulkan sekitar tiga kali lipat dari data yang diperlukan.

3. Data yang dikumpulkan harus dipahami Pemahaman tentang data yang dikumpulkan dan diolah untuk penelitian juga sangat penting. Data yang sifatnya numerik perlu dipahami artinya dan satuannya sehingga saat dikombinasikan dengan data dari sumber - sumber yang lain tidak terjadi kesalahan dalam pengintegrasian dalam sebuah sumber data tunggal.Pemahaman yang baik dari data - data yang dikumpulkan akan memudahkan dalam pengelolaan data dan juga interpretasi pada saat analisis

4. Data harus diolah sebelum diteliti

Data yang terkumpul, baik yang terpakai atau tidak terpakai perlu diolah terlebih dahulu sebelum dipergunakan untuk penelitian. Beberapa hal yang patut diperhatikan saat pengolahan data adalah Strukturisasi data, menghapus duplikasi, mengapus data yang kosong.

\subsection{Tipe Data}

Untuk memahami sebuah data maka perlu diketahu tipe data tersebut. Data dikelompokkan menjadi dua jenis yaitu :

1. Data Kualitatif

Data kualitatif adalah data yang bersifat tidak terukur dan bukan dari hasil pengukuran yang memiliki total namun bersifat penafsiran manusia.

2. Data Kuantitatif 
Data kuantitatif adalah ata yang bersifat terukur dan dapat diolah dengan persamaan matematika.

\subsection{Sumber Data}

Berdasarkan sumbernya data dikelompokkan menjadi :

1. Data Primer

Data primer adalah data yang diambil langsung dari suatu pengukuran atau perhitungan. Data primer diperoleh dengan mengukur atau menghitung, mengambil sample, menyebarkan kuesioner, membangkitkan data dengan simulasi, menambang dan menambang dari internet.

2. Data Sekunder

Data sekunder adalah data yang dipakai dari publikasi lain. Dan tidak dipakai secara langsung sebagai sumber utama peneliti namun digunakan untuk pembanding. Data sekunder dapat didapat dengan mengambil data penelitian orang lain, dan memakai data olahan yang tersedia di internet

3. Data Tersier

Data Tersiser adalah data yang berasal dari sumber yang keabsahannya masih diragukan. Dalam publikasi ilmilah penggunaan data tersier ini sangat tidak dianjurkan.

\subsection{Pengumpulan Data}

(Nazir, 2011)Pengumpulan data adalah prosedur yang sistematis dan standar untuk memperoleh data yang diperlukan. Selalu ada hubungan antara metode pengumpulan data dengan masalah penelitian yang ingin dipecahkan. Masalah memebrikan arah dan mempengaruhi metode pengumpulan data. Banyak 
masalah yang dirumuskan tidak akan bisa terpecahkan karena metode untuk memperoleh data yang digunakan tidak memungkinkan, ataupun metode yang ada tidak dapat menghasilkan data seperti yang diinginkan. Secara umum metode pengumpulan data dapat dibagi atas beberapa kelompok yaitu metode pengamatan langsung, metode dengan menggunakan pertanyaan dan metode khusus.

1. Pengumpulan data dengan pengamatan langsung Pengumpulan data dengan pengamatan langsung adalah cara pengambilan data dengan menggunakan panca indera manusia tanpa menggunakan alat bantu.

Keuntungan dari pengumpulan data dengan pengamatan langsung adalah

a. Data dari objek dapat dicatat segera dan tidak menggantungkan data dari ingatan seseorang.

b. Dengan pengamatan langsung dapat dikumpulkan data dari subjek yang dapat berkomunikasi verbal atau yang tidak mau berkomunikasi secara verbal.

Selain keuntungan diatas pengamatan secara langsung juga memiliki kekurangan diantaranya sebagai berikut :

a. Diperlukan waktu yang lama untuk memperoleh data melalui pengamatan langsung

b. Pengamatan terhadap suatu fenomena yang perubahannya begitu lama, tidak dapat dilakukan secara langsung 
c. Ada beberapa kegiatan yang tidak dapat di peroleh datanya secara langsung.

Secara umum , pengamatan secara langsung terbagi menjadi dua yaitu pengamatan tidak terstruktur dan pengamatan terstruktur.

a. Pengamatan yang tidak terstruktur

(Nazir, 2011)pada pengamatan tidak terstruktur, peneliti tidak mengetahui aspek - aspek apa dari kegiatan - kegiatan yang ingin diamatinya relevan dengan tujuan penelitiannya. Beberapa hal yang penting yang perlu diperhatikan dalam pengamatan tidak terstruktur adalah :

1) Isi dari pengamatan . karena tidak ada suatu ketentuan mengenai apa yang harus diamati oleh peneliti dalam pengamatan tidak terstruktur, maka perlu di lihat hal-hal seperti pastisipan , setting, tujuan, prilaku sosial, frekuensi dan lamanya kejadian.

2) Mencatat pengamatan. Dalam hal mencatat pengamatan yang tidak terstruktur, maka ada dua hal yang perlu diperhatikan yaitu waktu pengerjaan pencatatan dan bagaimana fenomena atau kejadian di catat.

3) Meningkatkan ketepatan pengamatan. Ada beberapa cara untuk meningkatkan ketepatan pengamatan yaitu menggunakan alat perekam, menggunakan kamera, pengamatan 
bukan dari satu orang saja tetapi terdiri dari lebih dari satu orang.

4) Hubungan antara pengamat dengan yang diamati

b. Pengamatan berstruktur

(Nazir, 2011)Pengamatan berstruktur adalah pengamatan yang si peneliti sudah mengetahui aspek apa dari aktivitas yang diamatinya yang relevan dengan masalah serta tujuan peneliti dengan pengungkapan yang sistematis untuk menguji hipotesisnya. Beberapa hal yang perlu di perhatikan dalam pengamatan berstruktur adalah :

1) Isi pengamatan. Karena peneliti sudah mengetahui isi dari observasinya maka peneliti dapat membuat perencanaan secara sistematis.

2) Mencatat pengamatan

3) Meningkatkan reliabilitas pengamatan. Reliabilitas pengamatan dapat ditingkatkan dengan :

a) Rumuskan definis dengan tepat tentang kategori.

b) Dalam menilai sebuah pengamatan peneliti harus memutuskan derajad keparcayaan terlebih dahulu agar peneliti memiliki pegangan dalam menilai pengamatan tersebut.

c) Hindari persepsi kepentingan pribadi atau nilai sendiri dalam pengamatan. 
d) Adakan latihan yang intensif terhadap pengamatan

e) Adakan pre-test pada kelompok kecil yang serupa dengan kelompk dimana pengamatan yang sebenarnya akan dilakukan.

f) Gunakan lebih dari satu orang pengamat.

4) Hubungan antara pengamat dan yang di amati.

2. Pengumplan data dengan wawancara

(Nazir, 2011)Wawancara adalah proses memperoleh keterangan untuk tujuan penelitian dengan cara tanya jawab, sambil tatap muka antara pewawancara dengan responden dengan menggunakan alat yang disebut interview guide (panduan wawancara).

Wawancara merupakan proses interaksi antara penanya dengan responden, ada beberapa faktor yang mempengaruhi interaksi dalam wawancara, antara lain sebagai berikut : 


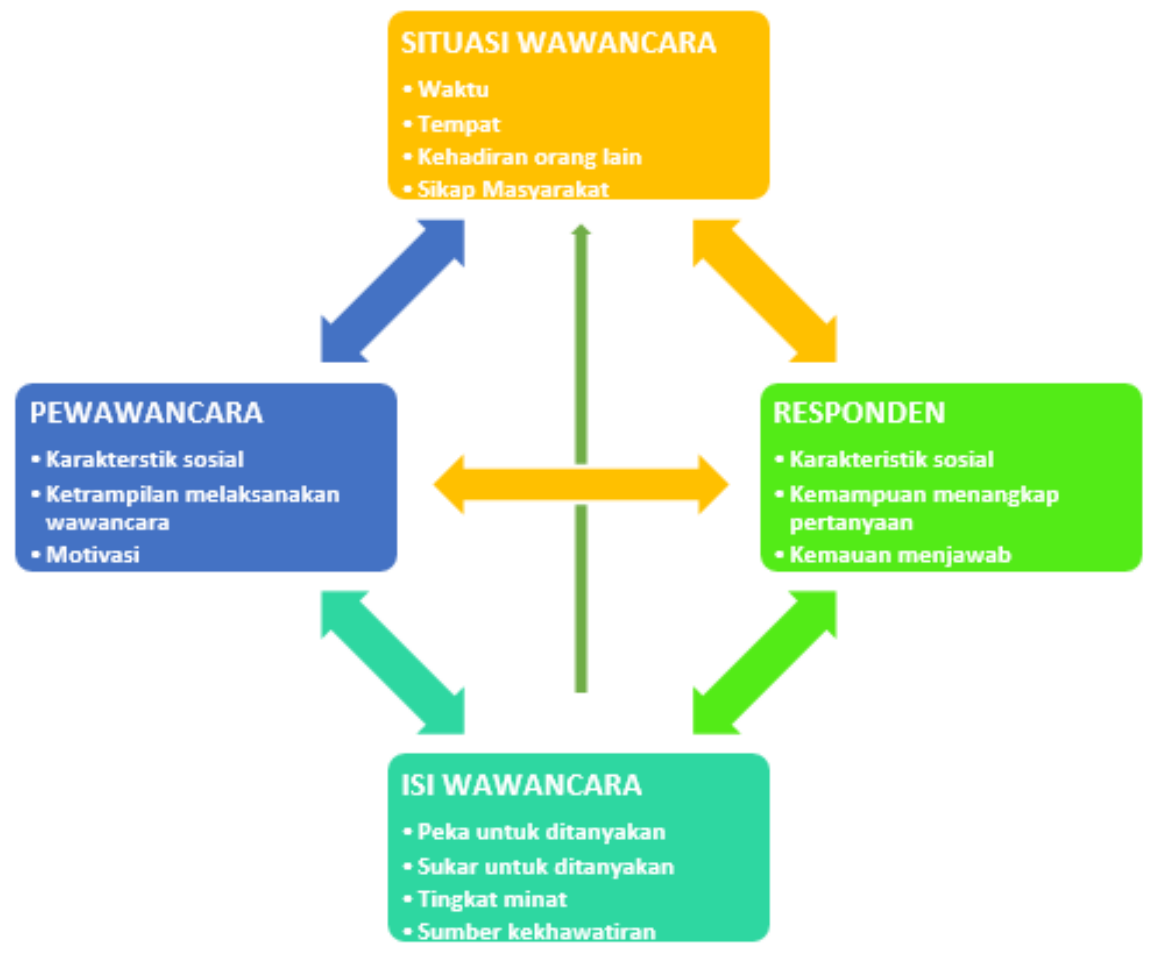

Gambar 4.1 Skema faktor yang mempengaruhi interaksi dalam wawancara

Situasi wawancara sangat di pengaruhi waktu, tempat, kehadiran orang lain dan sikap masyarakat. Untuk faktor yang mempengaruhi responden adalah karateristik sosial, kemampuan menangkap pertanyaan, kemauan menjawab pertanyaan. Pewawancara juga dipengaruhi beberapa faktor yaitu karakteristik sosial, ketrampilan melaksanakan wawancara dan rasa aman. Sedangkan isi wawancara dipengaruhi oleh 
peka untuk ditanyakan, sukar ditanyakan, tingkat minat dan sumber kekhawatiran. Suatu keserasian antara pewawancara, responden, dan situasi wawancara perlu dipelihara supaya terdapat suatu komunikasi yang lancar dalam wawancara.

Sasaran isi dari wawancara digunakan untuk memperoleh atau memastikan suatu fakta, memastikan kepercayaan tentang keadaan fakta, memastikan perasaan, memastikan suatu standar keadaan, mengetahui prilaku sekarang atau prilaku terdahulu dan untuk mengetahui alasan - alasan.

Prosedur dalam memulai wawancara dapat dilakukan dengan menerangkan kegunaan serta tujuan dari penelitian, menjelaskan mengapa responden terpilih untuk di wawancarai, menjelaskan institusi atau badan apa yang melaksanakan penelitian dan menerangkan bahwa wawancara tersebut merupakan sesuatu yang confidential.

Agar wawancara berjalan dengan baik seorang pewawancara dalam bertanya harus memiliki sikap netral, adil dan ramah.

3. Pengumpulan data melalui daftar pertanyaan

Alat lain untuk mengumpulkan data adalah melalui daftar pertanyaan atau yang disebut dengan Kuesioner.

(Nazir, 2011)Kuesioner adalah sebuah set pertanyaan yang secara logis berhubungan dengan masalah penelitian, dan tiap pertanyaan merupakan jawaban - jawaban yang mempunyai makna dalam menguji hipotesis. Beberapa hal yang perlu diperhatikan dalam mengumpukan data melalui kuesioner adalah : 
a. Isi dari kuesioner

Kuesioner harus fokus pada masalah yang ingin dipecahkan, setiap pertanyaan merupakan bagian dari hipoteisi yang ingin diuji. Secara umum isi kuesioner dapat berupa pertanyaan tentang fakta, pertanyaan tentang pendapat dan pertanyaan tentang persepsi diri.

Ada beberapa hal yang perlu diketahui dalam mengungkapkan pertanyaan yaitu perkataan dan kalimat harus sederhana, pertanyaan sebaiknya khas, pertanyaan jangan berarti dua, jangan gunakan kata yang samar samar artinya, pertanyaan yang mengandung sugesti, pertanyaan presumasi, hindarkan pertanyaan yang membuat malu atau terlalu pribadi bagi responden, hindarkan pertanyaan yang memerlukan ingatan yang kuat dari responden.

Ada dua jenis pertanyaan yaitu pertanyaan berstruktur dan pertanyaan terbuka. Pertanyaan berstruktur yaitu pertanyaan yang dibuat dibatasi dengan beberapa jawaban alternatif. Sedangkan pertanyaan terbuka adalah pertanyaan yang jawaban serta cara pengungkapannya dapat bermacam - macam.

Dalam membuat pertanyaan, susunlah pertanyaan menurut kelompok kerangka pemikiran tertentu dan jangan meloncat dari satu kerangka ke kerangka lain. 
Penguatan materi !

1. Kumpulkan sumber data melalui beberapa teknik baik wawancara, survei atau teknik yang lain. 


\section{BAB VIII VALIDITAS DAN RELIABILITAS}

Untuk mengukur konsep secara nyata berhubungan dengan validitas yang berarti seberapa valid data tersebut. Sedangkan untuk mengukur konsep secara akurat berhubungan dengan reliabilitas yang berarti seberapa akurat dapat diandalkan.

\subsection{Validitas}

Menurut (Sukardi, 2004)validitas adalah derajad yang menunjukkan dimana suatu tes mengukur apa yang hendak diukur.

Menurut (Azwar, 2014)validitas mengacu sejauh mana akurasi suatu tes atau skala dalam menjalankan fungsi pengukurannya.

Menurut (Echdar, 2017)validitas menunjukkan seberapa nyata suatu pengujian pengukuran apa uang seharusnya diukur. Validitas berhubungan dengan ketepan alat ukur untuk melakukan tugasnya mencapai sasarannya. Validitas berhubungan dnegan kenytaan dan tujuan dari pengukuran itu sendiri. Pengukuran dikatakan valid jika mengukur tujuannya dengan nyata atau benar. Alat ukur yang tidak valid adalah yang memberikan hasil ukuran menyimpang dari tujuannya. Penyimpangan pengukuran ini disebut dengan kesalahan (error) atau varian.

Jadi validitas adalah derajad yang menunjukkan akurasi suatu pengujian dalam menjalankan fungsi pengukuran. 


\subsection{Reliabilitas}

Menurut (Sekaran, 2006)reliabilitas suatu pengukuran menunjukkan stabilitas dan konsistensi dari suatu instrumen yang mengukur suatu konsep dan berguna untuk mengakses "kebaikan" dari suatu pengukuran.

Menurut (Ghozali, 2005)menyatakan bahwa reliabilitas adalah alat untuk mengukur suatu kuesioner yang merupakan indikator dari peubah atau konstruk. Suatu kuesioner disebut handal atau reliabel jika jawaban yang diberikan oleh responden terhadap pernyataan konsisten dari waktu ke waktu.

Menurut (Echdar, 2017)tinggi rendahnya reliabilitas, secara empirik ditunjukkan oleh suatu angka yang disebut nilai koefisien reliabilitas. Reliabilitas yang tinggi ditunjukkan dengan nilai rxx mendekati nilai 1 . Kesepekatan secara umum reliabilitas yang dianggap sudah cukup memuaskan jika $\geq 0.700$. Pengujian reliabilitas instrumen dengan menggunakan rumus Alpha Cronbach karena instrumen penelitian berbentuk angket dan skala bertingkat. Rumus Alpha Cronbach sebagi berikut :

$$
r_{11}=\left(\frac{n}{n-1}\right)\left(1-\frac{\Sigma \sigma t^{2}}{\sigma t^{2}}\right)
$$

Keterangan :
$r_{11}$
$=$ Reliabilitas yang dicari
$n$
$=$ Jumlah item pertanyaan yang diuji 
$\Sigma \sigma t^{2}=$ Jumlah varians skor tiap - tiap item

$\sigma t^{2} \quad=$ Varians total

Jadi jika nilai alpha $>0.7$ artinya reliabilitas mencukupi.

\subsection{Validitas Eksternal dan Internal}

Menurut (Echdar, 2017)Instrumen yang valid harus mempunyai validitas internal dan eksternal. Instrumen yang mempunyai validitas internal adalah jika kriteria yang ada dalam instrumen secara rasional telah mencerminkan apa yang di ukur. Sedangkan validitas eksternal menunjukkan bahwa dari suatu penelitian valid jika dapat di generalisasikan ke semua objek , situasi dan waktu yang berbeda.

Validitas Internal terbagi menjadi tiga kelompok yaitu validitas isi, validitas yang berhubungan dengan kriteria dan validitas konstruk.

\section{Validitas isi}

Validitas yang berisi tes yang menguji isi yang relevan dengan tujuan yang diukur . Contohnya misalkan kita akan mengukur image sebuah institusi pendidikan dan di dalam instrumen mengukur terntang opini masyarakat , tanggung jawab sosialnya dan dimensi - dimensi tersebut dianggap mewakili apa yang diukur yaitu image instansi pendidikan maka pengukuran terhadap image instansi pendidikan dianggap mempunyai validitas yang baik.

\section{Validitas Kriteria}

Validitas kriteria digunakan untuk mengukur perbedaan perbedaan berdasarkan kriteria yang digunakan. Contohnya adalah tes untuk mengukur etika mahasiswa pada suatu instansi pendidikan, terdapat dua kelompok 
yaitu yang sering datang terlambat dan yang datang tepat waktu. Skor hasil tes di bandingkan dan di korelasikan.

\section{Validitas Konstruk}

Validitas konstruk adalah validitas yang berkaitan dengan tingkatang skala yang mencerminkan dan peran konsep yang diukur.

\subsection{Pengujian Validitas Instrumen}

Menurut sugiono dalam (Echdar, 2017) Uji validitas adalah langkah pengujian yang dilakuakn terhadap isi dari suatu instrumen, dengan tujuan untuk mengukur ketepatan instrumen yang digunakan dalam suatu penelitian.

Tujuan dari pengujian validitas instrumen adalah mengetahui sejauhman keakuratan suatu instrumen pengukuran dalam melakukan fungsinya dan data yang diperoleh relevan dengan tujuan diadakannya pengukuran tersebut.

Reliabilitas instrumen merupakan syarat untuk pengujian validitas instrumen. Pengujian validitas instrumen dalam penelitian dilakukan dengan tiga pendekatan yaitu :

1. Pengujian Validitas Konstruk

2. Pengujian Validitas Isi

3. Pengujian Validitas Eksternal

\subsection{Pengujian Reabilitas Instrumen}

Menurut (Echdar, 2017) Uji reliabilitas adalah proses pengukuran terhadap ketepatan dari suatu instrumen. Pengujian dimaksudkan untuk menjamin instrumen yang digunakan merupakan instrumen yang 
handal, konsisten, stabil dan dependibilitas sehingga bila digunakan berkali - kali , dapat menghasilkan data yang sama. Pengujian reliabilitas instrumen dapat dilakukan secara eksternal maupun internal. Secara eksternal, pengujian dilakulan dengan test-retest, ekuivalent dan gabungan keduanya. Sedangkan secara internal , reliabilitas instrumen dapat diuji dengan menganalisis konsistensi dan butir-butir yang ada pada instrumen dengan teknik tertentu

\subsection{Instrumen Penelitian}

Menurut (Arikunto, 2010) Instrumen penelitian adalah sesuatu yang penting dan strategis kedudukannya dalam pelaksanaan penelitian.

Menurut Sugiono dalam (Echdar, 2017) Instrumen penelitian adalah suatu alat yang digunakan mengukur fenomena alam maupun sosial yang diamati. Ada dua kategori instrumen yang digunakan dalam penelitian yaitu :

1. Instrumen digunakan untuk memperoleh informasi atau data tentang keadaan objek atau proses yang diteliti.

2. Instrumen digunakan untuk mengontrol objek atau proses yang diteliti.

\section{Cara Menyusun Instrumen}

Untuk menyusun instrumen diperlukan variabel - variabel penelitian yang telah ditetap kan untuk di teliti. Kemudian variabel tersebut didefinisikan operasiobalnya kemudian di tentukan indikator - indikator yang akan di ukur kemudian dari indikator tersebut di jabarkan menjadi pertanyaan - pertanyaan. 
Menurut (Echdar, 2017) ada beberapa hal yang perlu diperhatikan dalam penyusunan instrumen penelitian , sebagai berikut :

1. Pengadaan instrumen yang baik

a. Perencanaan

b. Penulisan butir pertanyaan

c. penyuntingan

2. Pemilihan instrumen yang sesuai dengan metodenya

a. Instrumen untuk metode tes adalah tes atau soal tes

b. Instrumen untuk metode angket atau kuesioner adalah angket atau kuesioner

c. Instrumen untuk metode observasi adalah chek list

d. Instrumen untuk metode dokumentasi adalah pedoman observasi atau dapat juga check list (Arikunto, 2010)

3. Waktu pemilihan metode

a. Angket, digunakan bila responden jumlahnya besar dapat membaca dengan baik dan dapat mengungkapkan hal - hal yang sifatnya rahasia.

b. Observasi , digunakan apabila objek penelitian bersifat prilaku manusia, proses kerja , gejala alam , responden kecil

c. Wawancara, digunakan bila ingin mengetahui hal - hal dari responden secara lebih mendalam serta jumlah responden sedikit. 
d. Gabungan ketiganya , digunakan bila ingin mendapatkan data yang lengkap, akurat dan konsisten.

Penguatan materi !

1. Dari data yang telah dikumpulkan uji validitas dan reliabilitasnya . 


\section{BAB IX ANALISIS DAN INTERPRETASI DATA}

\subsection{Analisis Data}

Setelah data penelitian di dapat dan di rangkung dalam bentuk angka - angka maka langkah selanjutnya adalah melakukan analisis data yang bertujuan untuk memperoleh gambaran yang bermanfaat dari semua data yang telah didapat.

Menurut (Echdar, 2017) Analisis data dalah proses perhimpunan atau pengumpulan, pemodelan dan transformasi data dengan tujuan untuk menyortir dan memperoleh informasi yang bermanfaat, memberikan saran , kesimpulan dan mendukung pembuatan keputusan penelitian.

Menurut Trochim dalam (Echdar, 2017) ada tiga tahapan dalam analisis data yaitu :

1. Pembersihan dan pengorganisasian data untuk analisis (preparasi data)

Preparasi data meliputi kegiatan memeriksa dan memaskkan data yaitu memeriksa keakuratan data, memasukkan data ke program komputer , mengembangkan dan mendokumentasikan struktur database yang terintegrasi.

2. Deskripsi data (statistik deskriptik)

Statistik deskriptif digunakan untuk menggambarkan ciri - ciri dasar dari data hasil penelitian, dengan memberikan rangkuman sederhana tentang sampel dan ukuran. Disertai dengan grafik analisis sederhana , statistik 
deskriptif secara sederhana menggambarkan apa yang ditunjukkan oleh data.

3. Uji hipotesis dan model (statistik inferensial)

Statistik inferensial, meyelediki pertanyaan, model dan hipotesis. Dalam banyak kasus, kesimpulan dari statistik inferensial melebihi dari apa yang ditunjuukan oleh data itu sendiri. Sering kali seorang peneliti menggunakan statistik inferensial untuk membuat kesimpulan dari data terhadap kondisi yang lebih general.

Tujuan utama dari analisis data menurut (Echdar, 2017) ada tiga yaitu :

1. Mendapatkan perasaan terhadap data

Perasaan data bertujuan untuk melihat seberapa baik skala yang dibuat, seberapa baik pemodelan dan pemasukan datanya dan untuk memasukkan data untuk analisis faktor serta memperoleh keandalan dari pengukuran dan untuk memilih menu program piranti lunak yang sesuai.

2. Menguji ketepatan data

Pengujian ketepatan data dilakukan dengan meliputi kegiatan - kegiatan : keandalan yang dibuktikan dengan menguji konsistensi dan stabilitas, dan validitas yang hasilnya menegaskan apakah dimensi yang di teorikan muncul.

3. Pengujian hipotesis

Setelah mengetahui tujuan dari analisis data makas selanjutnya adalah proses pencatatan dan keakuratan data. Pencatatan data diperlukan untuk mencatat informasi dan menjaga keteraturannya hingga siap dianalisis. Sedangkan keakuratan data segera diperiksa oleh peneliti 
untuk memastikan tidak dijumpainya kesalahan atau permasalahan. Setelah data di catat dan di periksa keakuratannya data tersebut kemudian diberikan kode untuk memudahkan analisis.

Langkah selanjutnya adalah mengembangkan struktur data . Mengembangkan struktur data dilakukan dengan membuat codebook yang menggambarkan dan mengodentifikasi dimana dan bagaimana data dapat diakses. Codebook sebaiknya memuat informasi : nama variabel, deskripsi variabel, format variabel (nomor, data, teks), instrumen atau metode pengumpulan data, tanggal pengumpulan data, responden (individu atau grup), lokasi variabel di database dan catatan.

Setelah dibuat codebook langkah selanjutnya adalah proses memasukkan data ke program komputer. Melalui program tersebut peneliti dapat memeriksa apakah semua data telah masuk batasan atau limit yang diterima.

\subsection{Pengujian Hipotesis}

Menurut (Echdar, 2017) Berdasarkan arah atau bentuk informasi hipotesis, pengujian hipotesis dibedakan atas tiga jenis :

1. Pengujian hipotesis dua pihak

2. Pengujian hipotesis pihak kiri

3. Pengujian hipotesis pihak kanan

Langkah - langkah yang dipergunakan dalam menyelesaikan pengujian hipotesis statistik adalah :

1. Menentukan formulasi hipotesis

2. Menentukan taraf nyata $(\alpha)$

3. Menentukan kriteria pengujian 
4. Menentukan nilai uji statistik

5. Membuat kesimpulan

\subsection{Interpretasi Data}

Intepretasi data bertujuan untuk memaknai data sehingga data mudah dibaca. Analisis yang akurat dan penyajian yang tepat akan membuat intepretasi hasil penelitian yang akurat dan valid. Beberapa teknik untuk melakukan interpretasi data antara lain (Echdar, 2017) :

1. Dengan menghubungkan data dengan pengalaman peneliti.

2. Dengan mengaitkan temuan data dengan hasil kajian pustaka atau teori terkait.

3. Memperluas analisis dengan mengajukan pertanyaan mengenai penelitian dan implikasi hasil penelitian.

\subsection{Statistik Deskriptif}

Menurut M. Subana,dkk dalam (Echdar, 2017) mengemukakan bahwa statistik deskriptif adalah statistik yang menggambarkan kegiatan pengumpulan data, penyusunan data, pengolahan data dan penyajian data dalam bentuk tabel, grafik ataupun diagram, agar memberikan gambaran yang teratur, ringkas dan jelas mengenai suatu keadaan atau peristiwa. Analisis deskriptif bertujuan untuk memberikan gambaran tentang sesuatu data, seperti rata - rata (mean), jumlah(sum), simpangan baku (standard deviation), varians (variance), rentang (range), nilai maksimum, nilai minimum dan sebagainya.

Statistik deskriptif dapat dinyatakan dengan frekuensi, mode, dan keragaman . 
1. Frekuensi (F)

Frekuensi dinyatakan dengan presentase, bentuk yang tepat dalam menampilkan data frekuensi adalah diagram dan grafik.

2. Mode dan Median

Mode adalah nilai yang sering muncul pada suatu kasus . sedangkan median adalah nilai tengah , pembagi data.

3. Mean (M)

Mean merupakan rataan dari skor yang diukur.

4. Keragaman (variability)

Merupakan salah satu teknik untuk mengelompokkan data pada teknik statistik deskriptif. Menjalankan statistik deskriptif pada SPSS dapat melalui menu-bar analyse $\rightarrow$ descriptive statistic $\rightarrow$ descriptives.

\subsection{Statistik Inferensial}

Menurut Burhan Nurgiyantoro dalam (Echdar, 2017)Statistik Inferensial adalah statistik yang berkaitan dengan analisis data sampel untuk kemudian dilakukan penyimpulan - penyimpulan yang digeneralisasikan kepada seluruh subjek tempat data diambil/populasi. Berdasarkan asumsi yang mendasarinya statistik Inferensial terbagi menjadi dua yaitu :

1. Statistik Parametrik

Pendugaan dan uji hipoteissi dari parameter populasi berdasarkan anggapan bahwa skor - skor yang dianalisis telah ditarik dari suatu populasi dengan distribusi tertentu.

2. Statistik Nonparametrik 
Pendugaan dan pengujian hipoteisis dari parameter populasi berdasarkan anggapan nahwa skor yang dianalisis telah ditarik dari suatu populasi dengan bebas sebaran tidak mengikuti distribusi tertentu.

\section{Penguatan materi !}

1. Analisis dan interpretasikan data yang telah diuji validitas dan reabilitasnya . 


\section{BAB X TEMUAN PENELITIAN}

Setelah data di analisis maka dihasilkan berbagai temuan - temuan. Tahapan selanjutnya bagi seorang peneliti adalah menyampaikan hasil kesimpulan akhir untuk para pembaca karya penelitiannya. Penyajian temuan - temuan penelitian dapat disajikan sebagai berikut (Echdar, 2017) :

1. Pendahuluan

Peneliti menyajikan pengantar bagi pembaca yang berisi tentang temuan - temuan utama penelitian yang dilakukannya.

2. Ringkasan Penelitian

Ringkasan penelitian ini disajikan dimulai dari penyajian singkat atas masalah, masalah penelitian, telaah pustaka yang telah dilakukan hingga menghasilkan hipoteissi serta ringkasan hasil pengujian empirik yang dilakukan.

3. Simpulan atas masing - masing hipotesis

Peneliti menyampaikan kesimpulan yang dapat ditarik sebagai akibat dari diterima atau ditolaknya hipoteisi yang telah diuji.

4. Simpulan atas masalah penelitian

Peneliti menyajikan kesimpulan atas masalah penelitiannya .

5. Implikasi teori

Pada bagian ini peneliti menyajikan gambaran lengkap mengenai kontribusi signifikan terhadap ilmu pengetahuan dalam teori - teori yang digunakan untuk memecahkan masalah penelitian

6. Implikasi manajerial

Pada bagaian ini peneliti menyajikan berbagai implikasi kebijakan yang dapat dihubungkan dengan temuan temuan yang dihasilkan dalam penelitian. 
7. Keterbatasan penelitian

Pada bagian ini peneliti menyajikan keterbatasan keterbatasan penelitian yang dialami selama proses penelitian.

8. Implikasi metodologi

Bagian ini bersifat opsional dan menyajikan refleksi peneliti mengenai metodologi yang digunakan dalam penelitian.

9. Agenda penelitian mendatang

Pada bagian ini peneliti membantu peneliti lainnya untuk melanjutkan penelitian dalam bidang yang sama atau yang terkait langsung dengan penelitian ini baik menyangkut topik penelitian atau metode yang digunakan dalam penelitian.

Penguatan materi !

1. Buatlah kesimpulan dari hasil analisis data . 


\section{BAB XI PENULISAN LAPORAN PENELITIAN}

Setelah peneliti melakukan penelitian, langkah selanjutnya yang dilakukan seorang peneliti adalah menuliskan laporan penelitian. Laporan penelitian ini berfungsi untuk mendesimilasikan penelitian yang telah dilakukan sehingga hasil penelitian kita dapat diketahui oleh orang lain. Dengan diketahuinya hasil penelitian maka dapat dimanfaatkan oleh peneliti lain, dapat dijadikan sebagai rujukan atau reference. Untuk membuat laporan penelitian kita dapat menggunakan kerangka sebagai berikut :

\subsection{Pendahuluan}

\section{Latar Belakang}

Latar belakang berisi tentang suatu gejala atau masalah yang kemudian diuraikan menjadi topik atau masalah yang menjadi isu penelitian berdasarkan data atau informasi yang telah di dapat.

Masalah utama penelitian harus berdasar pada fakta yang disajikan, bukan persepsi atau dikarang atau diperkirakan sendiri.

Latar belakang memuat tentang mengapa kejadian atau gejala yang terjadi dianggap masalah dan alasan mengapa penting untuk diteliti dan apa dampak yang ditimbulkan jika masalah tersbeut di biarkan.

Penelitian biasanya didasari dari suatu masalahan yang terjadi saat lampau, saat ini atau saat esok, yang kemudian akan dicari penyelesaiannya. Jika penelitian berasal dari permasalaan yang ada di lingkungan sekitar, maka pada bagian latar 
belakang ini dapat diuraikan masalah - masalah yang ada, dapat dilengkapi dengan hasil survey, potongan berita atau laporan ilmiah mengenai masalah - masalah tersebut.

Jika penelitian yang dilakukan merupakan pengembangan dari suatu sistem atau alat, maka dapat diuraikan pada bagaian ini mengenai kondisi sistem atau alat tersebut dan kekurangan kekurangannya yang dianggap perlu untuk dikembangkan lebih lanjut.

Jika penelitian yang dilakukan merupakan pengembangan dari penelitian - penelitian yang sebelumnya , maka dapat dijelaskan pada bagian ini , penelitian - penelitian yan dimaksudkan, kemudian jelaskan perbedaannya dari hasil penelitian - penelitian tersebut dan jelaskan bagian mana yang harus dilakukan perbaikan atau peningkatan.

Pada intinya latar belakang harus berisi point point sebagai berikut :

a. Kondisi umum yang mendukung saat ini

b. Kondisi suatu bidang secara spesifik yang akan ditinjau

c. Masalah yang terjadi di bidang spesifik tersebut tinjau dari past, present, future

d. Deskripsikan permasalahan tersebut tentang perkiraan penyebabnya, karakteristik dari masalah, dampak dari masalah tersebut terhadap sistem secara lebih luas. 
e. Deskripsikan solusi - solusi yang mungkin dapat mengatasi permasalahan tersebut.

f. Jelaskan mengapa solusi tersbeut dipilih

g. Deskripsikan solusi yang peneliti usulkan

h. Ungkapkan pentinganya solusi peneliti yang berarti dampak atau keunggulan dibanding solusi lainnya.

\section{Rumusan Masalah}

Dalam menyusun rumusan masalah diawali dengan menampilkan faktor atau variabel yang teridentifikasi sebagai penyebab terjadinya masalah utama berdasar pada literatur atau penelitian terdahulu. Faktor- faktor penyebab masalah yang dikemukaka pada rumusan masalah adalah faktor terjangkau oleh peneliti atau yang berhubungan denga topik penelitian saja.

Setelah beberapa faktor terpilih untuk diteliti kemudian masalah dirumuskan dalam bentuk kalimat tanya yang operasional, terukur , observable padat, jelas dan tegas.

Rumusan masalah mejabarkan permasalahan permasalahan yang harus diselesaikan dalam mencapai tujuan. Setiap masalah dalam rumusan masalah akan mempunyai jawaban, baik dalam model sistem , lampiran ,analisa maupun kesimpulan.

Pada bagian latar belakang, dijelaskan permasalahan - permasalahan yang ada , yang menjadi sebab diadakannya penelitian. Pada bagian rumusan masalah ini, masalah yang telah dibahas 
sebelumnya di rumuskan menjadi suatu pernyataan yang ringkas dan tepat.

\section{Tujuan Penelitian}

Tujuan dari penelitian adalah pernyataan tentang apa yang akan dicapai atau dihasilkan dari penelitian tersebut. Tujuan penelitian harus konsisten dengan rumusan masalah penelitian.

\section{Manfaat Penelitian}

Menurut (Echdar, 2017)Manfaat penelitian dapat dibedakan menjadi manfaat ilmiah atau teoritis dan manfaat praktis dari hasil penelitian, yakni sebagai berikut :

a. Manfaar ilmiah , yaitu memberikan sumbangan pemikiran terhadap perkembangan ilmu pengetahuan yang ada relevansinya dengan bidang ilmu yang sedang dipelajari atau di teliti.

b. Manfaat praktis yaitu manfaat penelitian bagi dunia praktis di lapangan.

\section{Metode Penelitian}

Menyatakan cara atau pendekatan yang digunakan untuk menyelesaikan permasalahan penelitian. Pendekatan yang dilakukan dapat menggunakan studi literatur, pengukuran empirik, analisa statistik, simuasi, implementasi metodologi pengembangan sistem seperti agile, waterfall, prototipe, dan lain - lain.

\section{Ruang Lingkup}

Bagian ini menjelaskan tentang batasan masalah , kondisi - kondisi atau asumsi - asumsi yang 
berlaku pada rumusan masalah yang dibuat. Batasan tidak boleh terlalu melebar atau terlalu sempit, harus cukup rasional untuk keadaan sebenarnya.

\subsection{Kajian Pustaka}

Pada bagian kajian pustaka diisi dengan teori - teori yang relevan dengan masalah penelitian, konsep dan teori yang digunakan berdasarkan rujukan yang tersedia terutama karya ilmiah yang dipublikasikan baik nasional terakreditasi maupun internasional bereputasi. Kajian pustaka berfungsi membangun konsep atau teori yang akan menjadi landasan atau dasar studi dalam penelitian.

Menurut (Echdar, 2017) Pada kajian pustaka diuraikan konsep - konsep , dimensi - dimensi , indikator - indikator , unsur - unsur, ciri - ciri, langkah - langkah, aturan - aturan , hukum - hukum , teori - teori, perudang - undangan, dalil - dalil yang ada hubungannya dengan variabel yang diteliti berdasarkan referensi kepustakaan yang mendukung. Kajian pustaka dikutip secara penuh atau hasil kristalisai penulis. Kajian pustaka juga berisi tentang hasil kajian empirik dari hasil - hasil penelitian terdahulu yang relevan, yang dimuat dalam karya ilmiah terakreditasi , untuk di sintesiskan dengan teori - teori yang ada.

Pada bagian ini diuraikan mengenai sistem , cara kerja, metode , algoritma , pendekatan dan deskripsi dari kasus penerapannya.

\subsection{Analisis, Pemodelan dan Perancangan}

Pada bagian ini dilakukan pendefinisian aktivitas kerangka kerja yang dilakukan untuk menentukan 
tindakan - tindakan yang sesuai dengan permasalahan yang akan diselesaikan. Setelah mendefiniskan kemudian dilakukan identifikasi himpunan pekerjaan untuk mendiskripsikan pekerjaan - pekerjaan yang harus diselesaikan untuk memenuhi sasaran tujuan penelitian.

Setelah himpunan pekerjaan di tetapkan kemudain dilakukan pemodelan terhadap desain dari interpretasi solusi yang di usulkan oleh peneliti.

Setelah dilakukan pemodelan, langkah selanjutnya adalah melakukan perancangan dari hasil desain yang telah dibuat .

\subsection{Hasil dan Pembahasan}

1. Hasil Penelitian

Hasil penelitian ini berisi tentang proses pengujian - pengujian dari hasil perancangan yang telah dilakukan. Pada pengembangan sistem informasi pada bagian ini dapat berupa intepretasi proses pengujian alfa testing, beta testing, whitebox testing, blackbox testing, uji validitas, dan lain lain.

2. Pembahasan

(Echdar, 2017) Dalam bagian ini berisi pembahasan hasil penelitian, baik secara teoritis maupun empiris, yang kemudian disintesiskan dengan hasil penelitian terdahulu untuk mencari konvergensi dan divergensinya. Pada bagian ini merupakan proses berfikir sintesis antara deduksi dan induksi. Dikemukakan temuan - temuan penelitian, termasuk fenomena baru yang mungkin muncul selama penelitian . 
Pada pengembangan sistem informasi bagian ini dapat diisi dengan intepretasi hasil pengujian kebermanfaatan dari produk yang dikembangkan atau yang di rancang, yang dikaitkan dengan rumusan masalah dan tujuan penelitian.

\subsection{Simpulan, Implikasi dan Saran}

1. Simpulan

Simpulan harus dapat menjawan terhadap masalah yang dirumuskan, kesimpulan harus konsiten dengan masalah yang dirumuskan, tujuan dan manfaat penelitian, hipoteissi, hasil penelitian dan pembahasannya.

2. Saran dan Implikasi Hasil Penelitian

Saran merupakan resep dalam rangka pemecahan masalah, oleh karena itu saran menggambarkan keguanaan praktis dari implikasi hasil penelitian. Saran dan implikasi hasil penelitian harus berdasar pada kesimpulan dan harus memberikan kesempatan pada peneliti lain yang akan mengungkapkan secara mendalam.

\subsection{Daftar Pustaka}

Daftar pustaka berisi tentang semua pustaka yang digunakan dalam penulisan, yang disusun berdasarkan kriteria tertentu.

Penguatan materi !

1. Buatlah laporan penelitian dengan panduan kerangka bab 11. 


\section{BAB XII CONTOH KERANGKA LAPORAN PENELITIAN PRAKTEK KERJA LAPANGAN}

\subsection{Judul}

Pada laporan penelitian praktek kerja lapangan, untuk merumuskan judul perlu dipertimbangkan beberapa hal seperti ruang lingkup, tujuan dan topik atau tema yang diambil . Kemudian judul dirumuskan dalam satu kalimat yang ringkas, komunikatif dan afirmatif.

Contoh 1 :

Rancang bangun aplikasi presensi siswa jurusan rekayasa perangkat lunak berbasis mobile.

Dari judul diatas dapat diidentifikasi :

Ruang lingkupnya adalah presensi siswa jurusan rekayasa perangkat lunak. Topik/tema yang diambil adalah aplikasi berbasis mobile. Tujuannya adalah membangun aplikasi presensi berbasis mobile.

Contoh 2 :

Rancang blueprint IT pada sekolah A

Dari judul diatas dapat diidentifikasi ruang lingkupnya adalah kebutuhan IT untuk sekolah A. Topik atau tema yang diambil adalah blueprint IT. Tujuannya adalah merancang blueprint IT untuk sekolah A

\subsection{Lembar Persetujuan}

Lembar persetujuan merupakan halaman yang berisi pernyataan bahwa laporan penelitian praktek kerja 
lapangan yang disusun telah disetujui oleh pembimbing praktek kerja lapangan.

\subsection{Lembar Pernyataan}

Halaman lembar pernyataan merupakan halaman yang berisi pernyataan bahwa laporan yang disajikan adalah benar - benar dilakukan dan disusun oleh peneliti yang tercantum pada laporan tersebut

\subsection{Kata Pengantar}

Kata pengantar merupakan prakata dari penyusun dari laporan penelitian tersebut. Di dalam kata pengantar terdapat ucapan terima kasih , isi garis besar dari laporan serta harapan dari laporan penelitian tersebut.

\subsection{Daftar Isi}

Daftar isi merupakan daftar list tetang point - point yang di jelaskan dalam laporan penelitian praktek kerja lapangan tersebut.

\subsection{Daftar Lampiran}

Daftar lampiran merupakan daftar data yang menjadi pendukung dari penelitian praktek kerja lapangan . Daftar lampiran dapat berupa instrumen penelitian seperti kuesioner, hasil wawancara, dan lain - lain.

\subsection{Daftar Tabel}

Daftar tabel merupakan data tabel yang tertuang dalam laporan penelitian praktek kerja lapangan.

\subsection{Daftar Simbol}

Daftar simbol merupakan penjelas dari simbol - simbol atau notasi - notasi yang digunakan dalam laporan 
penelitian praktek kerja lapangan tersebut. Simbol simbol atau notasi - notasi tersebut dapat berupa :

1. Notasi/simbol yang digunakan dalam desain flowchart

2. Notasi/simbol yang digunakan dalam desain UML (Usecase, activity diagram, diagram squence , class diagram)

3. Notasi/simbol yang digunakan dalam desain diagram alir yaitu data flow diagram

4. Notasi/simbol yang digunalan dalam desain mockup

5. Notasi/simbol yang digunakan dalam desain arsitektur jaringan

\subsection{Daftar Gambar}

Daftar gambar merupakan data gambar yang tertuang pada laporan penelitian praktek kerja lapangan.

\subsection{Pendahuluan}

1. Latar Belakang

Pada latar belakang terdapat beberapa point diantaranya adalah :

a. Reasoning dan konsep umum

Berisi tentang perkembangan dari tema atau topik yang dipilih yang relevan dengan ruang lingkup objek penelitian. Contohnya adalah perkembangan teknologi informasi atau sistem informasi yang relevan dengan ruang lingkup objek penelitian.

b. Kondisi dan fakta masalah

Kondisi dan fakta masalah mendeskripsikan secara lengkap gambaran seluruh proses yang dianggap sesuai dengan temuan 
masalah, ini dilihat dari tiga perspektif yaitu input, proses dan output. Dengan melihat ketiga perspektif tersebut dapat ditemukan beberapa masalah dan dapat di rencanakan beberapa solusi untuk menyelesaikan permasalahan penelitian

c. Fokus penelitian

Setelah seluruh operation yang berjalan pada objek penelitian yaitu input, proses dan output maka, dapat dipilih fokus yang dapat dijadikan inti dari penelitian.

2. Identifikasi Masalah

Berisi tentang daftar permasalahan - permasalahan yang di temukan, kemudian dari daftar tersebut dipilih fokus yang akan diselesaikan yang dakan dijadikan sebagai rumusan masalah.

3. Alasan Pemilihan Judul

Berisi tentang alasan mengapa fokus masalah yang dipilih menjadi hal yang terpenting yang harus segera di solusikan. Dalam poin ini juga dibuat pernyataan akan penetapan judul yang tepat untuk pelaporan praktek kerja lapangan.

4. Ruang Lingkup

Ruang lingkup ini berisi tentang lingkup permasalahan yang diteliti dan yang akan diselesaikan dalam penelitian.

5. Tujuan dan Manfaat

Tujuan berisi tentang capaian yang dapat diraih dari kegiatan praktek kerja lapangan dengan mempertimbangkan objek penelitian. Sedangkan manfaat dapat di identifikasi berdasarkan stakeholder akan dapat merasakan hasil dari penelitian . 
6. Sistematika Penulisan

Sistematika penulisan merupakan kerangka dari laporan penelitian dalam praktek kerja lapangan.

\subsection{Hasil Pelaksanaan Praktek Kerja Lapangan}

1. Lokasi / tempat praktek kerja lapangan

a. Profile

Profile ini berisi tentang profil objek penelitian yang biasanya terdiri dari gambaran dasar tentang objek penelitian.

b. Struktur Organisasi

Struktur organisasi ini berisi tentang informasi mengenai susunan tanggung jawab pekerjaan dalam objek penelitian.

c. Pembimbing lapangan

Pada poin ini di intepretasikan tentang profil dari pembimbing lapangan pada obyek penelitian.

d. Jadwal praktek kerja lapangan

Jadwal praktek kerja lapangan dapat di representasikan dengan milestone gantt chart dari kegiatan atau aktivitas yang dilakukan ketika praktek kerja lapangan pada objel penelitian dari awal proses praktek kerja lapangan sampai berakhirnya prosesnya praktek kerja lapangan.

Representasi kegiatan atau aktivitas kerja dapat disesuaikan dengan metodologi yang dipilih seperti agile unified process, scrum , extreme program, dan lain - lain.

e. Peralatan praktek kerja lapangan Peralatan praktek kerja lapangan dapat berupa instrumen - instrumen penggalian 
data seperti daftar pertanyaan wawancara, schedule kegiatan, kuesioner pengumpulan data, cheksheet pengumpulan data, dan lain - lain .

2. Pengumpulan data

Pengumpulan data ini merupakan data atau informasi mentah yang di dapat dari kegiatan praktek kerja lapangan . ini dapat berupa hasil wawancara, hasil kuesioner, hasil checksheet pengumpulan data, dan lain - lain.

\subsection{Analisis Hasil Pelaksanaan Praktek Kerja}

\section{Lapangan}

1. Kendala - kendala dalam pelaksanaan praktek kerja lapangan

Kendala - kendala ini merupakan kesulitan kesulitan yang dihadapi dalam kegiatan praktek kerja lapangan.

2. Analisis terhadap ruang lingkup objek yang diteliti Analisis ini berisi tentang pendeskripisian hasil pengumpuan data seperti prosedur yang berjalan , infrastruktur, kopetensi sumber daya manusia yang ada dalam objek penelitian.

3. Temuan atau permasalahan penelitian

Temuan ini merupakan hasil kesimpulan permasalahan yang didapat dari hasil analisis terhadap ruang lingkup objek yang diteliti.

4. Usulan penyelesaian permasalahan penelitian

a. Usulan Prosedur (sistem / infrastruktur)

Usulan prosedur berupa aliran prosedur baru yang dapat menyelesaikan masalah penelitian.

b. Usulan desain (sistem /infrastruktur) 
Usulan desain ini dapat berupa desain case dari usulan prosedur, atau desain aktivitas yang terkait dengan usulan prosedur. Dalam pengembangan sistem informasi terdapat beberapa desain yaitu Data Flow Diagram , Use case, activity diagram, diagram squence, class diagram, desain arsitektur sistem, desain arsitektur infrastruktur jaringan, desain mockup, dan lain - lain.

c. Usulan kompetensi SDM

Usulan kompetensi SDM dapat berupa kompetensi - kompetensi yang harus dimiliki oleh pelaku yang ada dalam lingkup objek penelitian sehingga dapat menyelesaikan masalah penelitian.

\subsection{Kesimpulan Dan Saran}

Kesimpulan berisi tentang rangkuman dari kegiatan praktek kerja lapangan. Dalam kesimpulan ini di deskripsikan secara singkat tentang temuan masalah, solusi yang usulkan. Sedangkan saran berisi tentang keterbatasan dalam penelitian sehingga dapat disarankan tindak lanjut dari penelitian yang telah dilakukan.

\subsection{Daftar Pustaka}

Daftar pustaka berisi tentang daftar sumber informasi yang digunakan dalam penelitian seperti buku, jurnal, dan lain - lain .

\subsection{Lampiran - lampiran}

Lampiran berisi tentang dokumen - dokumen yang di dapat dari proses penelitian. 


\section{BAB XIII CONTOH KERANGKA LAPORAN PENELITIAN SKRIPSI /TUGAS AKHIR}

\subsection{Projek Jaringan Komputer}

Contoh dari projek ini adalah membangun jaringan wireless LAN pada kantor x. Berikut kerangka yang dapat digunakan :

\section{Judul}

Lembar pengesahan

Pernyataan

Abstrak

Kata Pengantar

Daftar Isi

Daftar Gambar

Daftar Tabel

Daftar Istilah

Daftar Notasi /Simbol

Bab 1 Pendahuluan

1.1. Latar belakang

1.2. Rumusan Masalah

1.3. Batasan Masalah

1.4. Tujuan

1.5. Manfaat

1.6. Metode Penelitian

1.7. Sistematika Penulisan

Bab 2 Landasan Teori

2.1. Pengertian Sistem Jaringan Komputer

2.2. Manfaat Jaringan Komputer 
2.3. Klasifikasi Jaringan Komputer

2.4. Tipe Jaringan Komputer

2.5. Topologi Jaringan Komputer

2.6. Perangkat Keras Jaringan Komputer

2.7. Media Transmisi

2.8. Metode Transmisi

2.9. Model OSI Layer

2.10. Protokol Jaringan

2.11. Wireless LAN

2.12. Acses Point

2.13. Konsep dasar teknologi Wi-Fi

2.14. Studi sejenis

\section{Bab 3 Metodologi Penelitian}

3.1. Metode Pengumpulan Data

3.2. Metode Pengembangan sistem menggunakan Network Developement Life Cycle

\section{Bab 4 Analisa dan Pembahasan}

4.1. Profile Objek Penelitian

1. Visi dan Misi

2. Struktur Organisasi

4.2. Analisis

1. Identify

2. Understand

3. Analyze

4. Report

4.3. Design

1. Perancangan Topologi

2. Perancangan Sistem

3. Simulation Prototyping

4.4. Implementasi

1. Implementasi Konfigurasi Perangkat Keras 
4.5. Monitoring

1. Pengujian Fungsionalitas koneksi wireless

4.6. Manajemen Pemeliharaan

Bab 5 Penutup

5.1. Kesimpulan

5.2. Saran

Daftar Pustaka

Lampiran - lampiran

\subsection{Projek Pembuatan Alat (Arduino)}

Contoh project ini adalah rancang bangun sistem A menggunakan arduino. Berikut adalah kerangka yang adapat digunakan :

Judul

Lembar pengesahan

Lembar pernyataan

Kata pengantar

Abstrak

Daftar isi

Daftar gambar

Daftar tabel

Daftar istilah

Daftar notasi atau simbol

Bab 1 Pendahuluan

1.1. Latar belakang

1.2. Rumusan masalah

1.3. Tujuan dan manfaat

1.4. Batasan masalah

1.5. Metode penelitian

1.6. Sistematika penulisan 


\section{Bab 2 Landasan Teori}

2.1. Mikrokontroller

2.2. Arduino

2.3. Mikrokontroler Atmega328

2.4. Arduino Uno

2.5. Sensor Infra Red(IR)

2.6. Catu Daya

2.7. Liquid Crystal Display (LCD)

2.8. Root Mean Square Error (RMSE)

2.9. Java

2.10. Teori terkait

\section{Bab 3 Analisa dan Perancangan Sistem}

3.1. Analisa Sistem

3.2. Analisa Kebutuhan Sistem

3.3. Perancangan Sistem

1. Diagram Sistem

2. Flowchart Sistem

3. Perakitan Sensor

4. Cara Kerja Sistem

5. Desain Interface

\section{Bab 4 Implementasi dan Pengujian}

4.1. Implementasi Kebutuhan Sistem

1. Kebutuhan Perangkat Keras

2. Kebutuhan Perangkat Lunak

4.2. Implementasi Sistem

1. Implementasi perangkat keras

a. Arduino Shield

b. Rangkaian Arduno dan sensor

2. Implementasi perangkat lunak

a. Perhitungan sistem pada arduino

b. Tampilan GUI

3. Pengujian Sistem

a. Pengujian BlackBox 


\section{Bab 5 Penutup}

\section{b. Pengujian Alat}

5.1. Kesimpuan

5.2. Saran

\section{Daftar Pustaka}

Lampiran - lampiran

\subsection{Projek Artificial Intellegence}

Contoh project game : Penerapan Artificial Intellegence "Action Battle System" Pada Game Battle of Konoha

Judul

Lembar pengesahan

Kata pengantar

Abstrak

Daftar isi

Daftar gambar

Daftar tabel

Daftar istilah

Daftar notasi atau simbol

Bab 1 Pendahuluan

1.1. Latar belakang

1.2. Rumusan masalah

1.3. Batasan masalah

1.4. Tujuan dan manfaat

1.5. Metode penleitian

1.6. Sistematika penulisan

Bab 2 Landasan teori

2.1. Definisi game

2.2. Kategori game

2.3. Klasifikasi game 
2.4. Algoritma Rule-Based

2.5. Metode Reasoning pada Rule-Based

2.6. Engine Game

2.7. RPG Maker $V x$

2.8. Action Battle System

\section{Bab 3 Analisa perancangan sistem}

\subsection{Analisa sistem}

1. Analisa kebutuhan

2. Spesifikasi kebutuhan

a. Kebutuhan hardware

b. Kebutuhan software

c. Kebutuhan brainware

d. Kebutuhan fungsional

e. Kebutuhan non fungsional

3. Analisa karakter

4. Skenario game

5. Aturan main game

6. Level Enemy

3.2. Perancangan sistem

1. Navigasi map

2. Usecase diagram

3. Activity diagram

4. Resouce Game

a. Image atau gambar

b. Suara atau music

3.3. Perancangan desain interface

1. Perancangan desain menu utama

2. Perancanagn desain continue

3. Perancangan desain battle

4. Perancangan desain game over

\section{Bab 4 Implementasi dan pengujian}

\subsection{Implementasi}

1. Implementasi antar muka 
2. Cara mengompres dan extract game $\mathrm{BOK}$

4.2. Pengujian perangkat lunak

1. Pengujian fungsional game

2. Pengujian Rule Based dalam game BOK

3. Pengujian aplikasi game

\section{Bab 5 Kesimpulan dan saran}

5.1. Kesimpulan

5.2. Saran

\section{Daftar pustaka}

Contoh projek sistem pakar : Skin Disease Diagnosing Expert System By Using Forward Chaining Method

\section{Judul}

Lembar pengesahan

Lembar pernyataan

Kata pengantar

Daftar isi

Daftar gambar

Daftar tabel

Daftar notasi atau simbol

Abstrak

Bab 1 Pendahuluan

1.1. Latar belakang

1.2. Rumusan Masalah

1.3. Tujuan dan manfaat

1.4. Batasan masalah

1.5. Metode penelitian

1.6. Sistematika penulisan

Bab 2 Landasan teori

2.1. Sistem pakar

2.2. Komponen sistem pakar

2.3. Klasifikasi sistem pakar 
2.4. Karakteristik sistem pakar

2.5. Metode foward chaining

2.6. Kaidah produksi

2.7. Deductive reason

2.8. Penyakit kulit jamur

2.9. Rekayasa Perangkat Lunak

2.10. Model Proses rekayasa perangkat lunak Agile Unified Process

2.11. Unified Modeling Language

2.12. PHP

2.13. MySQL

\section{Bab 3 Analisis dan perancangan}

3.1. Analisa sistem

1. Analisa kebutuhan

2. Spesifikasi kebutuhan

a. Kebutuhan hardware

b. Kebutuhan software

c. Kebutuhan brainware

d. Kebutuhan fungsional

e. Kebutuhan non fungsional

3.2. Pemodelan sistem

1. Data Flow Diagram

2. Usecase diagram dan skenario usecase

3. Activity diagram

4. Class Diagram

3.3. Perancangan sistem

1. Perancangan Pengambilan Keputusan

2. Perancangan Antarmuka user

\section{Bab 4 Implementasi dan pengujian}

4.1. Implementasi

1. Implementasi untuk user

2. Implementasi untuk admin

4.2. Pengujian 
1. Pengujian Perangkat lunak

2. Pengujian terhadap user

\section{Bab 5 Penutup}

5.1. Kesimpulan

5.2. Saran

\section{Daftar Pustaka}

\subsection{Projek Sistem Informasi Berbasis Objek Website}

Contoh dari project ini adalah : Rancang Bangun Sistem Informasi Pengadaan Barang dan Jasa untuk Pengadaan Langsung menggunakan Agile Unified Process

\section{Judul}

Lembar pengesahan

Lembar pernyataan

Kata pengantar

Daftar isi

Daftar gambar

Daftar tabel

Daftar notasi atau simbol

Abstrak

Bab 1 Pendahuluan

1.1. Latar belakang

1.2. Rumusan Masalah

1.3. Tujuan dan manfaat

1.4. Batasan masalah

1.5. Metode penelitian

1.6. Sistematika penulisan

Bab 2 Landasan Teori

2.1. Pengadaan 
2.2. Organisasi Pengadaan

2.3. Garis Besar proses pengadaan barang dan jasa

2.4. Konsep Rekayasa Perangkat Lunak

2.5. Model Proses Rakayasa Perangkat Lunak Agile Unified Process

2.6. Penelitian terkait

\section{Bab 3 Analisis dan Perancangan}

3.1. Analisa sistem

1. Analisa kebutuhan

2. Spesifikasi kebutuhan

a. Kebutuhan hardware dan jaringan

b. Kebutuhan software

c. Kebutuhan brainware

d. Kebutuhan fungsional

e. Kebutuhan non fungsional

3.2. Pemodelan sistem

1. Pemodelan Input

2. Pemodelan Output

a. Pemodelan isi

b. Interaksi

c. Pemodelan fungsional

d. Pemodelan navigasi

e. Model konfigurasi

3.3. Perancangan sistem

3. Perancangan antarmuka input

4. Perancangan antarmuka output

\section{Bab 4 Implementasi dan pengujian}

4.1. Implementasi

1. Implementasi untuk user

2. Implementasi untuk admin

4.2. Pengujian

3. Pengujian Perangkat lunak

4. Pengujian terhadap user 


\section{Bab 5 Penutup}

5.1. Kesimpulan

5.2. Saran

Daftar Pustaka

\subsection{Projek Pemograman Animasi Kreatif}

Contoh dari projek ini adalah Perancangan Animasi Cerita Rakyat "Situ Bagendit" sebagai Media Pembelajaran Karakter Untuk Anak Usia Dini

Judul

Lembar pengesahan

Lembar pernyataan

Kata pengantar

Daftar isi

Daftar gambar

Daftar tabel

Daftar notasi atau simbol

Abstrak

Bab 1 Pendahuluan

1.7. Latar belakang

1.8. Rumusan Masalah

1.9. Tujuan dan manfaat

1.10. Batasan masalah

1.11. Metode penelitian

1.12. Sistematika penulisan

Bab 2 Landasan Teori

2.1. Animasi

1. Animasi 3D

2. Animasi 2D

3. Jenis - jenis Animasi

4. Proses Pembuatan Animasi 
2.2. Multimedia

2.3. Gaya Desain

2.4. Teori Psikologi dan Perkembangan Anak Usia Dini

1. Teori Psikodinamika

2. Teori Pembelajaran

3. Teori Kognitif

4. Perkembangan Anak Usia Dini

2.5. Situ Bagendit

1. Obyek Wisata Situ Bagendit

2. Cerita Rakyat Situ Bagendit

\section{Bab 3 Analisis dan Perancangan}

3.1. Profil Klien

1. TK. An-Nijam

2. TK. Mutmainah

3. TK. PGRI

3.2. Analisis

1. Analisis Masalah

2. Pemecahan Masalah

3.3. Perancangan

1. Perancangan Konsep komunikasi

2. Perancangan Konsep Media

3. Perancangan Konsep Kreatif

4. Perancangan Program Kreatif

3.4. Visualisasi

1. Karakter

2. Data Visual

3. Pengembangan Ide Visual (Karakter, Lingkungan, Tipografi)

4. Storyboard

\section{Bab 4. Hasil dan Pembahasan}

4.1. Hasil Pengembangan

4.2. Pembahasan Hasil Pengembangan

Bab 5. Penutup 
5.1. Kesimpulan

5.2. Saran

Daftar Pustaka

Lampiran 


\section{Daftar Pustaka}

Agustina, C. (2015). Pengembangan Media Pembelajaran

Teknik Animasi 2 Domensi Berbasis Adobe Flash

Untuk Siswa Kelas XI Multimedia SMK Muhamadiaha

Prambanan. Yogyakarta: Universitas Negeri

Yogyakarta.

Amin, Z. (2013, December 23). Metode Perancangan Jaringan dengan Model PPDIOO. Diambil kembali dari http://www.news.palcomtech.com: http://www.news.palcomtech.com/metodeperancangan-jaringan-dengan-model-ppdioo/

Arikunto, S. (2010). Manajemen Penelitian, Suatu Pendekatan Praktik. Jakarta: Rineka Cipta.

Azwar, S. (2014). Metode Penelitian. Yogyakarta: Pustaka Pelajar.

Buzan, T. (2008). Buku Pintar Mind Map. Jakarta: PT. Gramedia Pustaka Utama.

Daniel. (2002). Pengantar Ekonomi Pertanian. Jakarta: Bumi Aksara.

Dhiaksa, A. (2016). Sistem Pakar Diagnosa Penyakit Kulit Menggunakan Metode Foward Chaining. Yogyakarta: Universitas Sanata Dharma.

Echdar, S. (2017). Metode Penelitian Manajemen dan Bisnis. Makasar: Ghalia Indonesia. 
Emanuel, A. W. (2017). Petunjuk Praktis Metode Penelitian Teknologi Informasi. Yogyakarta: Andi.

Ghozali, I. (2005). Aplikasi Analisis Multivariat dengan program SPSS. Bandung: Badan Penerbit Universitas Diponegoro.

H, M. N. (2018). Sistem Informasi Pengadaan Barang dan Jasa untuk Pengadaan Langsung dengan Agile Unified Process. Malang: Universitas Islam Negeri Maulana Malik Ibrahim.

Hadi, S. (2004). Metodologi Research. Yogyakarta: Andi Offset.

Hasan, M. I. (2002). Metode Penelitian dan Aplikasinya. Jakarta: Ghalia Indonesia.

Hendry. (2005). Metode Ilmiah dan Penelitian. Theory, Training and Research Net Work.

Irvan. (2017, February 10). NETWORK DEVELOPMENT LIFE CYCLE (NDLC). Diambil kembali dari pojokteknologi.com: https://pojokteknologi.com/id/2017/02/10/networkdevelopment-life-cycle-ndlc/

K, R. A. (2015). Perancangan Animasi Cerita Rakyat SITU BAGENDIT Sebagai Media Pembelajaran Karakter untuk Anak Usia Dini. Yogyakarta: Institut Seni Indonesia Yogyakarta.

Kuncoro, M. (2013). Metodologi Riset untuk Bisnis dan Ekonomi, Bagaimana Meneliti dan Menulis Tesis. Jakarta: Penerbit Erlangga. 
Leedy P.D, N. (1997). Practical Research : Planning and Design. Pearson Education.

Mardhiyah, N. (2011). Membangun Jaringan Wireless LAN pda Kantor Kelurahan Bintaro. Jakarta: Universitas Islam Negeri Syarif Hidayatullah.

Maulida, R. N. (2013). Rancang Bangun Pengendalian Penerangan Rumah Menggunakan SMS Berbasis Mikrokontroler AVR ATMEGA8535. Malang: Universitas Islam Negeri Maulana Malik Ibrahim.

Maxxor. (2018, 07 12). SCRUM Software Development Process. Diambil kembali dari www.maxxor.com: https://www.maxxor.com/software-developmentprocess

Mercubuana, T. D. (2015). Modul Perkuliahan Metodologi Penelitian Teknologi Informasi. Universitas Mercu Buana.

Nazir, M. (2011). Metode Penelitian. Bogor: Ghalia Indonesia.

Pariatra, W. (1981). Teknik - teknik Suvervisi. Yogyakarta:

Balai Pembinaan Administrasi , Akademi Administrasi Negara.

Prastowo, A. (2012). Metode Penelitian Kualitatif dalam Perspektif Rancangan Penelitian. Jogjakarta: Ar-Ruzz Media.

Purwanto, A. E. (2007). Metode Penelitian Kuantitatif untuk Administrasi Publik dan Masalah - masalah Sosial. Yogyakarta: Gaya Media. 
Receptives, T. (2018, 07 6). Spiral Methodology. Diambil kembali dari techreceptives.com:

https://techreceptives.com/development-methodologyspiral

Roger S. Pressman, P. (2012). Rekayasa Perangkat Lunak, Pendekatan Praktis Edisi 7. Yogyakarta: Andi.

Ruseffendi. (2005). Dasar - dasar Penelitian Pendidikan dan Bidang Non-Eksata Lainnya. Bandung: Tarsito.

SANTOS, J. M. (2017, 07 18). XP, FDD, DSDM, and Crystal Methods of Agile Development. Diambil kembali dari project-management.com: https://projectmanagement.com/xp-fdd-dsdm-and-crystal-methodsof-agile-development/

Schindle, D. R. (2006). Metode Riset Bisnis Volume 2 Edisi 9. Jakarta: PT. Media Global Edukasi.

Sekaran, U. (2006). Research Methods for Business;

Metodologi Penelitian untuk Bisnis, Buku 2 edisi 4. Jakarta: Salemba Empat.

Sugiono. (2016). Memahami Penelitian Kualitatif. Bandung: Alfabeta.

Sugiono. (Memahami Penelitian Kualitatif). Metode Penelitian Kuantitatif. Bandung: Alfabeta.

Sukardi. (2004). Metode Penelitian Pendidikan. Yogyakarta: Sinar Grafika Offset.

tatvasoft. (2015, 04 15). Top 12 Software Development Methodologies \& its Advantages / Disadvantages. Diambil kembali dari www.tatvasoft.com: 
https://www.tatvasoft.com/blog/top-12-softwaredevelopment-methodologies-and-its-advantagesdisadvantages/

Trochim, W. M. (2006, Oktober 10). Deduction \& Induction. Diambil kembali dari Web Center Social Research Method:

https://socialresearchmethods.net/kb/dedind.php

UKEssays. (2013). Research is the systematic process of collecting and analyzing. Diambil kembali dari UKEssays:

https://www.ukessays.com/essays/psychology/research -the-systematic-process-of-collecting-data-psychologyessay.php?cref $=1$

Umam, C. (2013). Penerapan Artificial Intelligence "Action Battle System" pada Game Battle of Konoha. Malang: Universitas Muhamadiyah Malang.

Wirartha, I. M. (2006). Pedoman Menulis Usulan Penelitian, Skripsi, dan Tesis dilengkapi dengan contoh - contoh dan metode analisis data. Yogyakarta: Penerbit Andi. 